Report No: AUS15036

Democratic Republic of São Tome and Príncipe Financial Sector Development Implementation Plan (FSDIP): 2017-2019

September 2016

\title{
GFM01
}

AFRICA

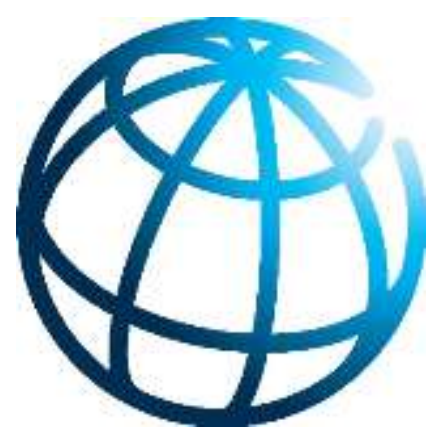




\section{Standard Disclaimer:}

This volume is a product of the staff of the International Bank for Reconstruction and Development/ The World Bank. The findings, interpretations, and conclusions expressed in this paper do not necessarily reflect the views of the Executive Directors of The World Bank or the governments they represent. The World Bank does not guarantee the accuracy of the data included in this work. The boundaries, colors, denominations, and other information shown on any map in this work do not imply any judgment on the part of The World Bank concerning the legal status of any territory or the endorsement or acceptance of such boundaries.

\section{Copyright Statement:}

The material in this publication is copyrighted. Copying and/or transmitting portions or all of this work without permission may be a violation of applicable law. The International Bank for Reconstruction and Development/ The World Bank encourages dissemination of its work and will normally grant permission to reproduce portions of the work promptly.

For permission to photocopy or reprint any part of this work, please send a request with complete information to the Copyright Clearance Center, Inc., 222 Rosewood Drive, Danvers, MA 01923, USA, telephone 978-750-8400, fax 978-7504470, http://www.copyright.com/.

All other queries on rights and licenses, including subsidiary rights, should be addressed to the Office of the Publisher, The World Bank, 1818 H Street NW, Washington, DC 20433, USA, fax 202-522-2422, e-mail pubrights@worldbank.org. 
Democratic Republic of São Tomé and Príncipe:

Financial Sector Development Implementation Plan:

2017-2019

September 2016
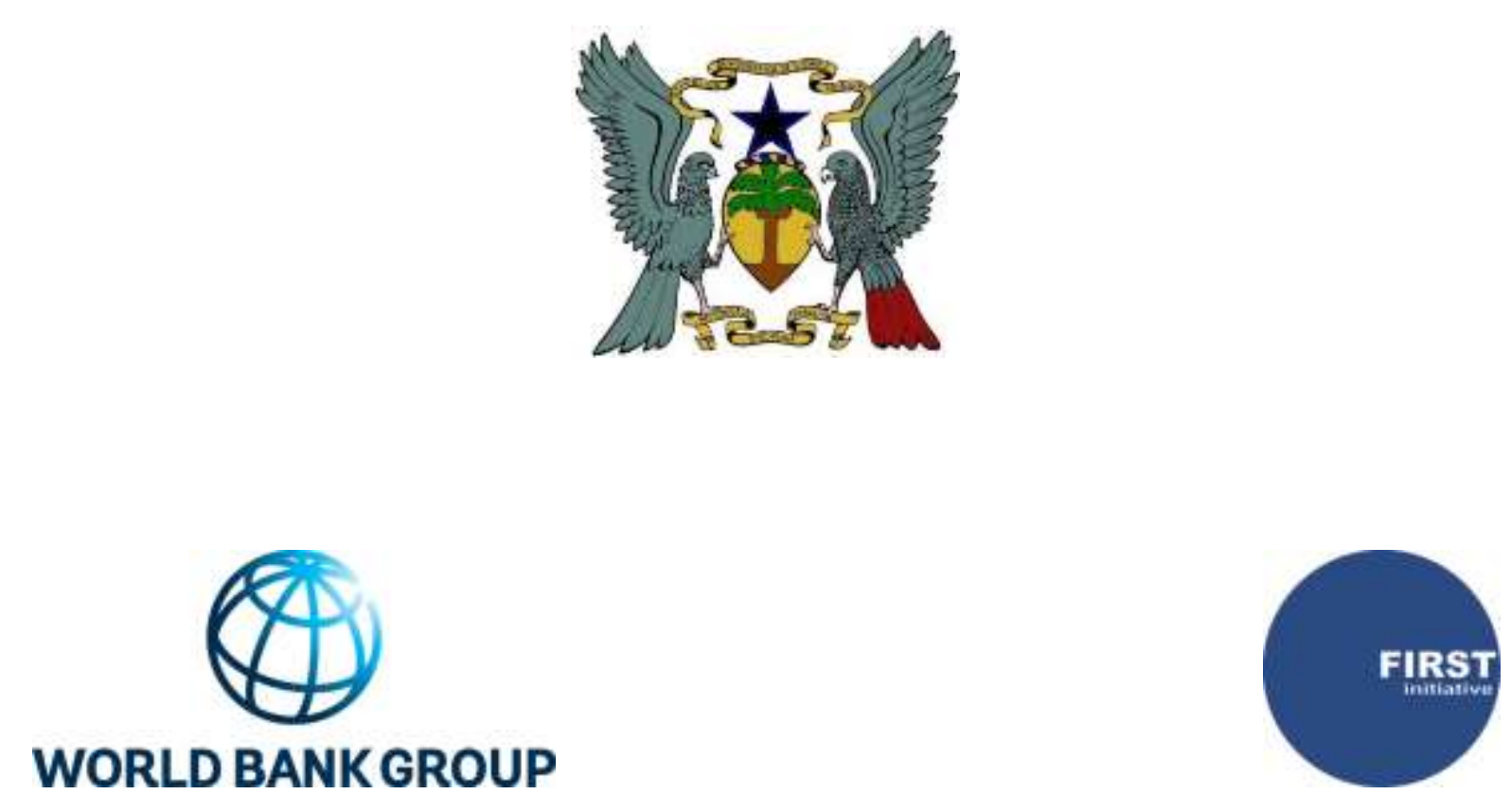


\section{CURRENCY EQUIVALENTS}

(Exchange Rate Effective February 21, 2016)

$$
\begin{aligned}
\text { Currency Unit } & =\text { Sao Tomean Dobra } \\
1 \text { USD } & =22,056 \text { STD }
\end{aligned}
$$

\section{FISCAL YEAR}

January 1 - December 31

\section{ABBREVIATIONS AND ACRONYMS}

$\begin{array}{ll}\text { BCSTP } & \text { Banco Central do São Tomé e Príncipe } \\ \text { EC } & \text { European Commission } \\ \text { EU } & \text { European Union } \\ \text { FDI } & \text { Foreign Direct Investment } \\ \text { GDP } & \text { Gross Domestic Product } \\ \text { IAS } & \text { International Accounting Standards } \\ \text { IFC } & \text { International Finance Corporation } \\ \text { IFRS } & \text { International Financial Reporting Standards } \\ \text { IMF } & \text { International Monetary Fund } \\ \text { INE } & \text { Instituto Nacional de Estatística } \\ \text { MIC } & \text { Middle Income Country } \\ \text { MOF } & \text { Ministry of Finance } \\ \text { NPL } & \text { Non-Performing Loan } \\ \text { NPRS } & \text { National Poverty Reduction Strategy } \\ \text { OTOCA } & \text { Order of Technical Accounting and Auditing Professionals } \\ \text { ROA } & \text { Return on Assets } \\ \text { ROE } & \text { Return on Equity } \\ \text { SOE } & \text { State-Owned Enterprise } \\ \text { STD } & \text { Sao Tomean Dobra } \\ \text { USD } & \text { United States Dollar }\end{array}$




\section{Table of Contents}

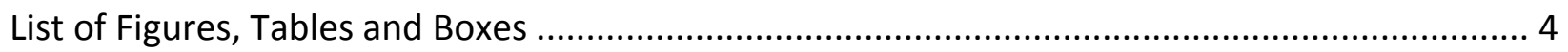

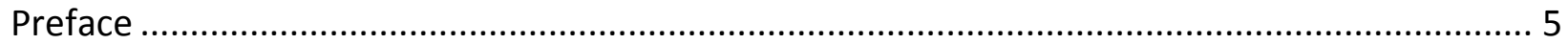

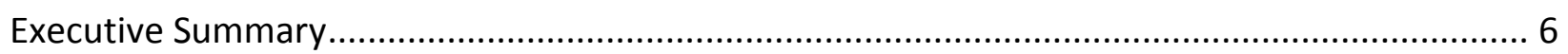

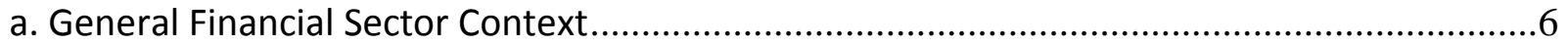

b. Strengthening Financial Sector Supervision .............................................................. 7

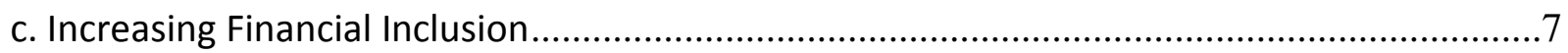

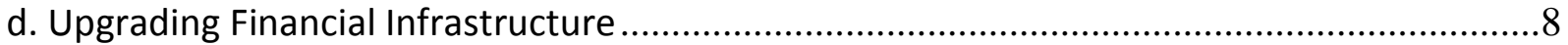

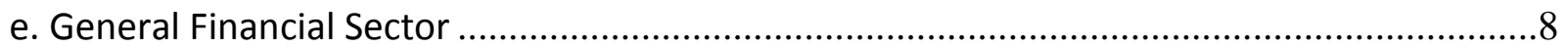

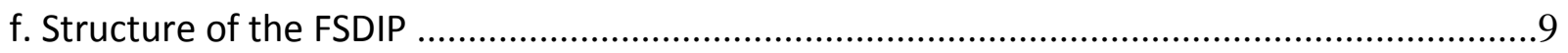

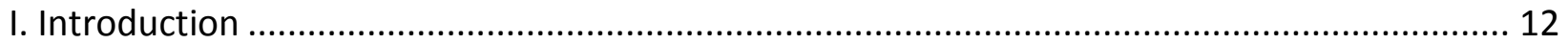

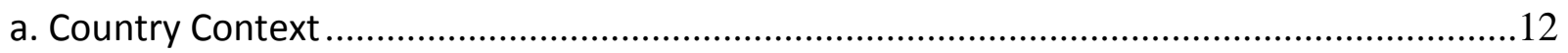

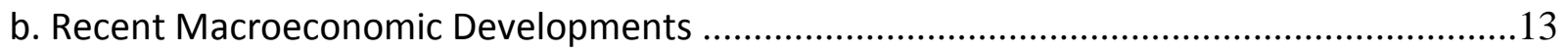

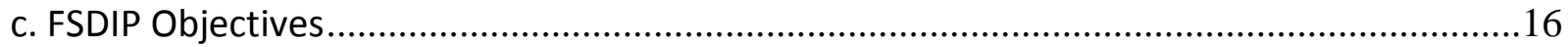

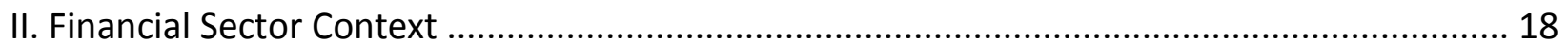

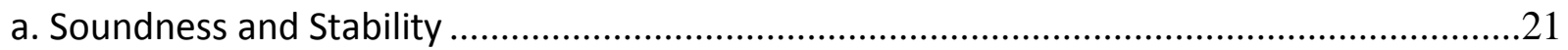

b. Performance

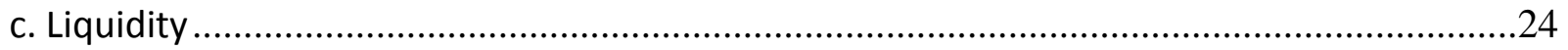

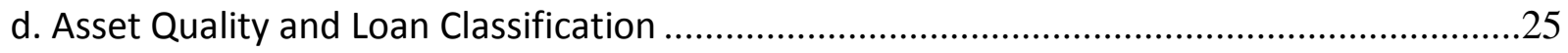

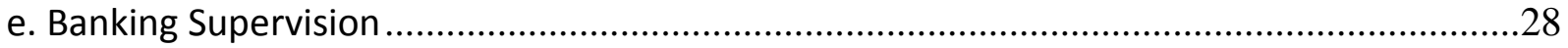

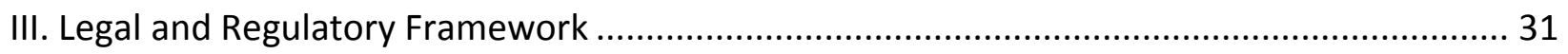

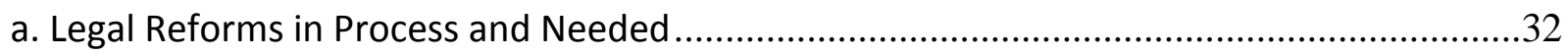

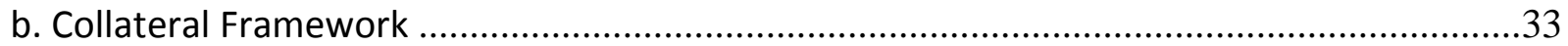

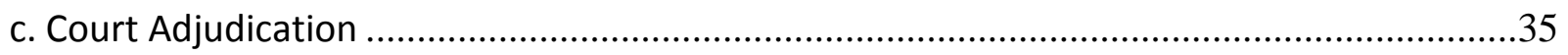

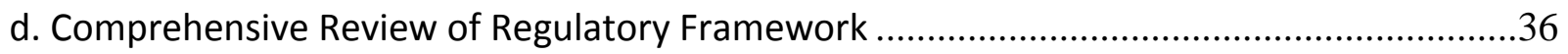

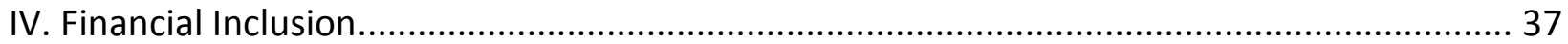

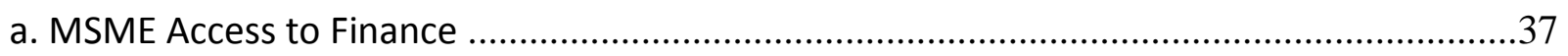

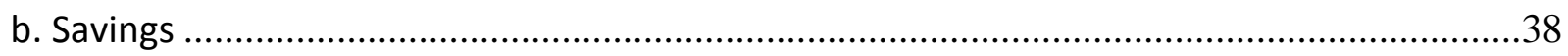

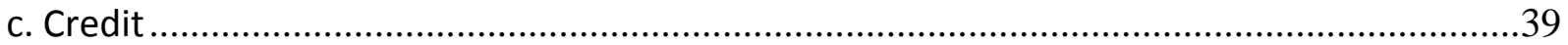

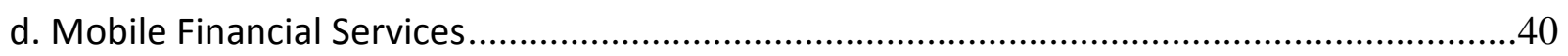

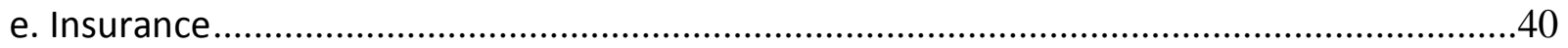

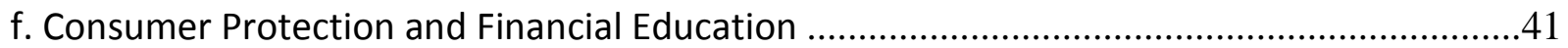

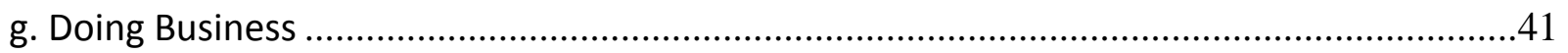

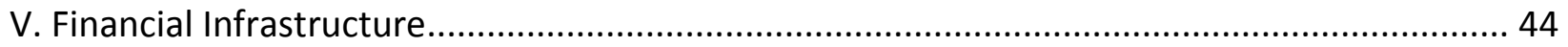

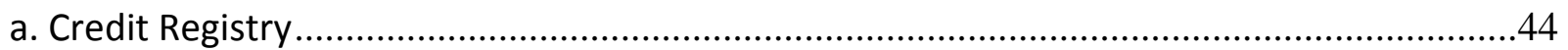

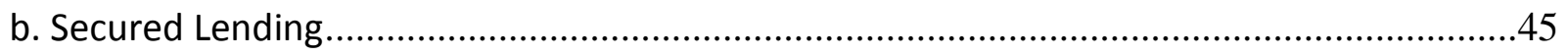

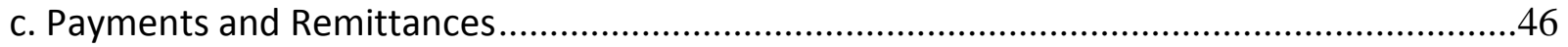

VI. Implementation, Monitoring and Evaluation of the FSDIP ......................................... 48

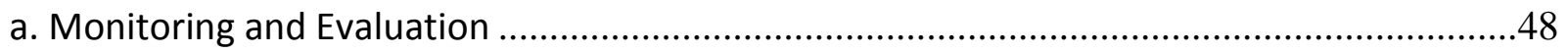

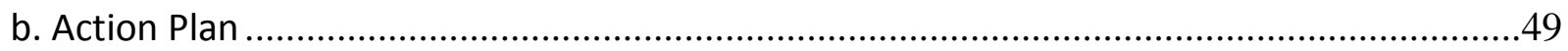


Annex 1: Action Matrix

Annex 2: Ongoing Donor Support to STP's Financial Sector................................................... 54

Annex 3: Consultation \& Dissemination Plan ................................................................... 55

Annex 4: Select Financial Soundness Indicators, 2011-2015................................................ 57

Annex 5: Small Financial Systems: Some Stylized Facts and Evidence from Sao Tome and

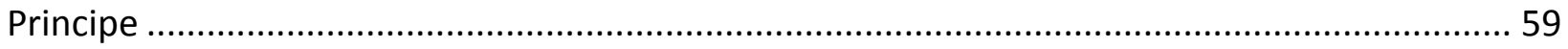

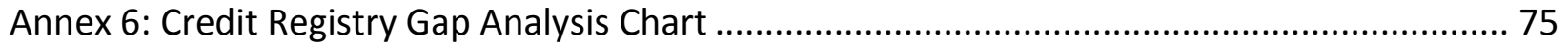

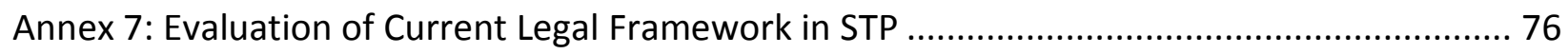

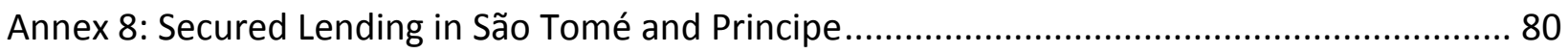

Annex 9: Secured Transactions Registry - Analysis of Institutional Framework ...................... 103

Annex 10: List of Individuals Met with and Meeting Agenda............................................. 111 


\section{List of Figures, Tables and Boxes}

Table 1: Summary of Key Recommendations ...................................................................... 9

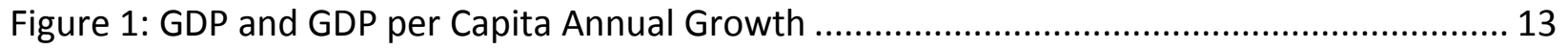

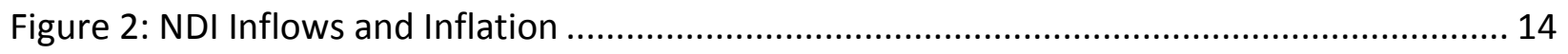

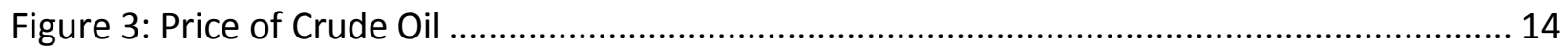

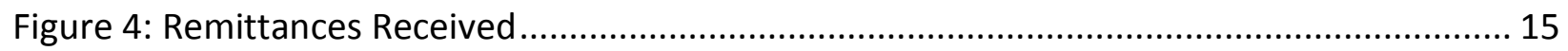

Figure 5: Building Blocks of Financial Sector Development in São Tomé and Príncipe............... 17

Table 2: Summary of Banking System in São Tomé and Príncipe as of December 2015 ............. 19

Figure 6: Market Share by Assets, Deposits and Loans, October 2015 ................................... 20

Figure 7: Private Credit to GDP and Interest Rate Spreads, Select Countries ........................... 20

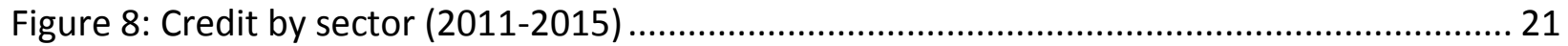

Figure 9: Interest Rate Spread Comparison, Select Countries, 2001-2014 ............................. 23

Figure 10: Industry NPLs as a Percent of Total NPLs and Gross NPLs by Industry ..................... 26

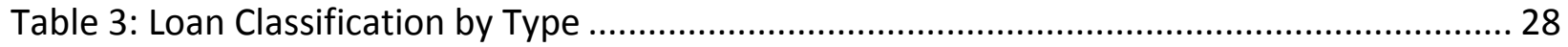

Table 4: Loans Secured by Movable and Immovable Collateral............................................ 28

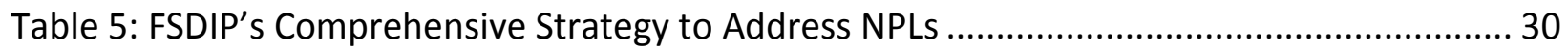

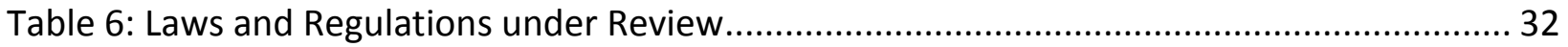

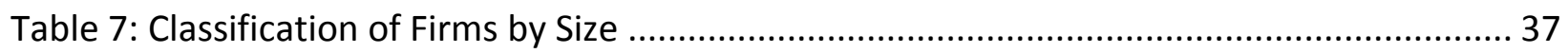

Figure 11: Geographic Distribution Bank Branches: Two Circled Districts Lack Access .............. 38

Table 8: Strength of Legal Rights Index in São Tomé and Príncipe......................................... 43

Box 1: Collateral Registries and Moveable Assets as Security.................................................. 46

Figure 12: Remittance Dependency, Select Countries, 2014 .............................................. 47

Figure 13: Governance Framework for the FSDIP ............................................................... 48 


\section{Preface}

The Government of São Tomé and Príncipe requested assistance in developing a coordinated, prioritized and well-sequenced roadmap for developing its financial sector. Staff from the World Bank Group's Finance and Markets Global Practice, with resources provided by the FIRST Initiative, visited São Tomé on four separate occasions from December 2014 to December 2015 to support work on a Financial Sector Development Implementation Plan (FSDIP). A preliminary draft of the FSDIP was discussed with the Government and Central Bank (Banco Central do São Tomé and Príncipe - BCSTP) on July 13, 2015 followed by a stakeholder workshop attended by representatives of all relevant public and private institutions, as well as civil society groups. A revised FSDIP was subsequently discussed with the Government and Central Bank during a financial sector mission to São Tomé and Príncipe December 4-8, 2015.

The main objective of this report is to contribute to the development of São Tomé and Príncipe's financial sector and provide its Government and private stakeholders with a clear roadmap for reform in key policy areas, particularly regarding efforts to strengthening financial sector soundness, enhance financial inclusion, and upgrade existing financial infrastructure. The report includes a sequenced implementation plan designed to enable the authorities to implement critical financial sector reforms and interventions, designed to foster a more efficient, sound and inclusive financial sector in São Tomé and Príncipe based on a coherent policy framework.

At the request of Governor of the Central Bank of São Tomé and Príncipe, Maria do Carmo Silveira, the support to the development of the FSDIP focuses primarily on measures to enhance the legal and regulatory framework. Given the size of the domestic banking sector, the primary focus of this implementation plan is on reforms to the banking system and financial infrastructure. Non-bank financial institutions, such as insurance and pension, are noted but not analyzed in detail as they make up a relatively small share of financial assets.

To prepare this document the task team met with the Prime Minister, Minister of Finance, the Governor and senior staff of the BCSTP, Minister of Economy, Minister of Justice, the national pension fund, management at the commercial banks, insurance firms and micro enterprises, the national chamber of commerce, representatives of microfinance, youth and professional associations, and other development partners. The team is grateful for the excellent cooperation received from all agencies and officials, the logistical support provided, and their time so generously provided as part of this work. ${ }^{1}$

\footnotetext{
${ }^{1}$ This document was prepared by a Finance and Markets Global Practice (GFMDR) team consisting of Julián Casal, Economist and Task Team Leader; Mazen Bouri. Senior Financial Sector Specialist and Technical Lead; Christopher Juan Costain, Lead Financial Sector Specialist; Dorothe Singer, Economist (DECFP), Elsa Rodriguez, Operations Analyst; Dave Grace, Consultant, Maria Chiara Malaguti, Consultant, Fabio Tarantini, Consultant, Fabio Pragmatica, Consultant, Adelino Castelo David, Consultant, and Nicholas Smith, Consultant. The report was prepared under the guidance of Irina Astrakhan, Practice Manager, GFM01. It benefited from comments and suggestions made by Yira Mascaró, Lead Financial Sector Specialist, Cédric Mousset, Lead Financial Sector Specialist, Valeria Salomão Garcia, Senior Financial Sector Specialist, Nataliya Mylenko, Senior Financial Sector Specialist, Caroline Cerruti, Senior Financial Sector Specialist, Rafael Barroso, Senior Country Economist, and Consolate
} 


\section{Executive Summary}

The São Tomé and Príncipe: Financial Sector Development Implementation Plan (FSDIP): 20172019 focuses on policy reforms and actions in three key areas: (i) strengthening financial sector supervision, (ii) increasing financial inclusion, and (iii) upgrading financial infrastructure. A key theme that emerges from the diagnostic work undertaken to prepare this document is the need to update or establish legal and regulatory frameworks to better connect the financial sector to the Government's overall priority, which is to create and bolster the conditions essential for growth, job creation, and poverty reduction in São Tomé and Príncipe.

\section{a. General Financial Sector Context}

São Tomé and Príncipe's financial sector development is best understood within the context of oil and the structure of its banking sector. The discovery of offshore oil in the 2000's resulted in a massive influx of capital and new entrants into the banking sector. Between 2004 and 2008, foreign direct investment increased from 3.3 to 41.7 percent of GDP, and the banking sector grew rapidly (spurred on by liberalization) from one state-owned bank, Banco Internacional de São Tomé e Príncipe (BISTP), which is now partially owned by banks from Portugal and Angola, to five new banks, all of which are international subsidiaries. ${ }^{2}$ Despite these changes, BISTP remains predominantly state-owned and market dominant with approximately two-thirds of total deposits, half of total assets and the bank branch network, and over three-quarters of all foreign currency deposits. BISTP's continued dominance ultimately provides it with a distinct advantage in servicing clients requiring foreign currency for financing imports and has important implications for market competitiveness. ${ }^{3}$

Unfortunately, the prospects of commercially viable oil have diminished in recent years, which has resulted in a significant drop in FDI, and produced lower, but steady levels of lending and economic growth. These factors, along with high interest spreads and a weak consumer protection framework have also resulted in non-performing almost loans doubling in the last five years. Due to these challenges and changing economic conditions, banking is largely not a profitable enterprise in São Tomé and Príncipe with the exception of BISTP. With the banking sector as a whole experiencing losses since 2012 and increasing asset deterioration, capital adequacy (which is presently above Basel and the regulatory minimum in STP) may begin to decrease in the near future. Yet, as the home markets of the parent banks are largely oil-

\footnotetext{
Rusagara, Senior Program Manager (FIRST), Emiko Todoroki, Senior Financial Sector Specialist (FIRST) and Marlon Rolston Rawlins, Financial Sector Specialist (FIRST).

2 As of 2016, there are seven banks.

${ }^{3}$ Foreign currency deposits make up 40 percent of all deposits in the banking system.
} 
economies, STP banks may not be able to recapitalize as these home markets are impacted by low oil prices.

\section{b. Strengthening Financial Sector Supervision}

The financial sector in São Tomé and Príncipe has come under some stress from the array of challenges that it faces. This stress is evident in Banco Central do São Tomé and Príncipe (BCSTP) having placed three banks under its administration since 2010 for failure to meet the minimum capital requirements.

BCSTP's capacity to supervise the banking system has gradually improved, but it remains limited. The authorities, recognizing the risks in the sector, have initiated an ambitious program of legal and regulatory reforms related to their financial sector. In particular, they have instituted a new Bank Resolution Law, which provides a framework for prompt corrective action and resolution of distressed institutions that moves past the previous focus on administration and liquidation.

To further address existing challenges to financial sector stability and soundness, and to prepare for eventual contingencies, the FSDIP recommends finalizing the reform efforts associated with core financial sector legislation, increasing the frequency of and quality of supervision (both onand off-site), implementing an action plan to reduce the volume of non-performing loans following completion of the asset quality review undertaken by BCSTP, and putting in place a financial stability committee to monitor risks in the sector and coordinate decision making.

\section{c. Increasing Financial Inclusion}

Although 48 percent of people have a savings account, there remains a significant amount of space to increase access to savings, and even more so for credit. In São Tomé and Príncipe, only 7 percent of micro, small and medium sized enterprises (MSMEs) have a bank loan, less than 5 percent of adults are clients of consumer finance firms and 4.3 percent of adults have some form of private insurance. Limited access to finance serves as a barrier to economic development and poverty reduction. Access to finance is constrained by high-interest rate spreads, a lack of an understanding of MSMEs financial needs and the absence of a bank branch in every district, agent banking and mobile money services. Increasing access to finance also requires parallel efforts in consumer protection. At present, the consumer protection framework only applies to banking customers and not to consumer finance or microfinance organizations, there is no standardized method of disclosure or framework to monitor over-indebtedness, and there is little interaction between market conduct and prudential supervision.

To address these challenges in financial inclusion and consumer protection, the FSDIP advocates: issuing guidelines on mobile money, permitting agent banking among financial institutions by allowing banks to partner with local firms as banking agents, bringing microfinance institutions 
and consumer lenders under central bank supervision, implementing standards for transparency of financial products and interest rates, and conducting an enterprise survey to better understand MSMEs financing constraints.

\section{d. Upgrading Financial Infrastructure}

São Tomé and Príncipe's financial infrastructure is insufficient to meet the needs of a growing and increasingly dynamic economy. Existing payments systems do not currently allow connection to international payments networks (e.g. Visa or MasterCard) and BCSTP maintains the only connection to the international SWIFT network. BCSTP also maintains a credit registry of all current bank loans, yet few lenders reference the credit registry for evaluating lending decisions given the gaps in its information, such as historical data and low periodicity. Similarly, the legal framework for the execution of collateral is outdated and does not adequately address borrowers' credit needs. There is also no centralized electronic registry for security interests in movable or immovable property or specific law on secured transactions.

To improve the payment system, it is necessary to implement a fully interoperable card payment system with international linkages, which the authorities have prioritized and will be supported by multilateral partners. Credit information availability would increase if BCSTP would require the registry to maintain historical data on borrowers and provide a more consolidated view of borrowers' credit history in the credit report. For collateral registries, the FSDIP recommends implementing an electronic movable and immovable collateral registry anchored in a modern secured transactions legal framework.

\section{e. General Financial Sector}

Lastly, but related to the preceding discussion of collateral, the diagnostic work identified broader issues related to the judicial framework for resolving commercial and financial disputes and the overall investment climate in São Tomé and Príncipe. The process for individuals and firms to receive judicial review of these disputes, including the execution of guarantees and registration of collateral, is unnecessarily long and burdensome. In line with the Government's Private Sector Development Strategy, it is necessary to train judges on commercial and financial adjudication techniques as well as streamline judicial review of small claims. Ultimately, poor contract enforcement reduces financial institutions willingness to lend and investors and companies willingness to invest in the economy.

Another issue of critical importance is the high degree of informality in São Tomé and Príncipe's economy. While addressing informality is outside the scope of a FSDIP, there are nevertheless numerous measures that can be taken to improve the quality of loan applications by MSMEs, as they are the main drivers of employment and economic growth in many countries. Chief among these is the need to develop stronger auditing and accounting techniques and standards in São 
Tomé and Príncipe. In light of this, the FSDIP recommends establishing a professional accountancy organization that supports accounting and financial statement preparation for MSMEs. Establishing this organization would help create a more sound, stable, and inclusive financial system and thus be an important step in achieving greater access to finance.

\section{f. Structure of the FSDIP}

The FSDIP is structured as follows: Section I contains an introduction with a description of the country context, recent macroeconomic developments, and objectives of the FSDIP; Section II focuses on the financial sector as a whole and assess its soundness and stability, performance, liquidity, asset quality and loan classification regime, and the quality of banking supervision; Section III provides an overview of the legal and regulatory reforms underway, the framework for the execution of collateral guarantees, and court adjudication; Section IV provides an assessment of the current state of financial inclusion and consumer protections; Section V proves an assessment of existing financial infrastructure including the credit registry, framework for secured lending, and payments systems; and Section VI concludes with the implementation arrangements and $M \& E$ framework of the action plan contained in the first annex. To facilitate the implementation of the FSDIP's recommendations, the FSDIP action plan is structured around three key strategic areas in the financial sector: Strengthening Financial Sector Supervision (A), Increasing Financial Inclusion (B), and Upgrading Financial Infrastructure (C), while also including a general strategic area (D). All recommendations are categorized by priority, a corresponding timeframe, and implementation status, and highlight the relevant government agency and donors, both actual and potential in nature. The table below summarizes the key recommendations of the FSDIP, and its priority and timeframe.

\section{Table 1: Summary of Key Recommendations}

\begin{tabular}{|l|l|l|l|l|}
\hline Strategic Area A: Strengthen Financial Sector Supervision & Priority & Status & Timeframe \\
\hline No. & Recommendation & $\begin{array}{l}\text { Partially } \\
\text { started } \\
\text { regulatory framework for the financial sector and amend new } \\
\text { legislation where pertinent. Specifically, finalize amendments to the } \\
\text { Central Bank Act and Financial Institutions Law and update rules and } \\
\text { regulations in accordance with the new law. Make all relevant laws, } \\
\text { rules and regulations available on government websites. }\end{array}$ & $\begin{array}{l}\text { months } \\
2 \text { (a) }\end{array}$ & $\begin{array}{l}\text { Enhance supervisory capacity for both off- and on-site supervision by } \\
\text { increasing frequency and robustness of on-site risk-based } \\
\text { examinations of banks by implementing a schedule for more frequent } \\
\text { examinations of banks. Provide additional staff to banking } \\
\text { supervision department. }\end{array}$ \\
\cline { 2 - 5 } 2 (b) & $\begin{array}{l}\text { Increase use of data currently gathered on the banking sector to } \\
\text { inform analysis and supervision of banking sector. In particular, there } \\
\text { is a need to conduct an asset quality review of banks and to analyze } \\
\text { key trends and risks to the sector, such as financial stability. }\end{array}$ & Started & Ongoing \\
\cline { 2 - 5 } 2 (c) & $\begin{array}{l}\text { Conduct a detailed assessment of banks compliance with Basel Core } \\
\text { Principles. }\end{array}$ & Medium & $\begin{array}{l}\text { Started } \\
\text { started }\end{array}$ & $\begin{array}{l}\text { First } \\
\text { months } \\
\text { months }\end{array}$ \\
\hline
\end{tabular}




\begin{tabular}{|c|c|c|c|c|}
\hline $2(d)$ & $\begin{array}{l}\text { Review arrangements for cross border banking supervision and } \\
\text { home-host cooperation. }\end{array}$ & Low & $\begin{array}{l}\text { Not } \\
\text { started }\end{array}$ & $\begin{array}{l}12-18 \\
\text { months }\end{array}$ \\
\hline $2(e)$ & $\begin{array}{l}\text { Review and revise bank licensing procedures to ensure due diligence } \\
\text { for new bank(s) entering the country and appropriate fit and proper } \\
\text { guidelines and regulations. }\end{array}$ & Low & $\begin{array}{l}\text { Not } \\
\text { started }\end{array}$ & $\begin{array}{l}12-18 \\
\text { months }\end{array}$ \\
\hline 3 (a) & $\begin{array}{l}\text { Conduct a comprehensive review of the regulatory framework } \\
\text { necessary to implement the new Bank Resolution Law, including } \\
\text { specific guidelines for the resolution of distressed financial } \\
\text { institutions. }\end{array}$ & High & $\begin{array}{l}\text { Partially } \\
\text { started }\end{array}$ & $\begin{array}{l}1-6 \\
\text { months }\end{array}$ \\
\hline 3 (b) & $\begin{array}{l}\text { Strengthen regulatory framework for prompt corrective actions, } \\
\text { improve contingency planning and establish coordination } \\
\text { mechanisms for crisis management. }\end{array}$ & Medium & $\begin{array}{l}\text { Partially } \\
\text { started }\end{array}$ & $\begin{array}{l}6-12 \\
\text { months }\end{array}$ \\
\hline \multicolumn{5}{|c|}{ Strategic Area B: Increase Financial Inclusion } \\
\hline No. & Recommendation & Priority & Status & Timeframe \\
\hline 4 (a) & $\begin{array}{l}\text { Finalize preparation of draft Microfinance Law and corresponding } \\
\text { rules and regulations. }\end{array}$ & Medium & $\begin{array}{l}\text { Partially } \\
\text { started }\end{array}$ & $\begin{array}{l}12-18 \\
\text { months }\end{array}$ \\
\hline 4 (b) & $\begin{array}{l}\text { Bring microfinance institutions and consumer lenders under central } \\
\text { bank market conduct and prudential supervision and ensure that } \\
\text { they participate in the central credit registry. }\end{array}$ & High & $\begin{array}{l}\text { Partially } \\
\text { started }\end{array}$ & $\begin{array}{l}1-6 \\
\text { months }\end{array}$ \\
\hline 4 (c) & $\begin{array}{l}\text { Implement market conduct and consumer protection standards for } \\
\text { transparency of financial products and interest rates by reviewing } \\
\text { joint orders and other publications, where such information is } \\
\text { published. }\end{array}$ & Medium & $\begin{array}{l}\text { Not } \\
\text { started }\end{array}$ & $\begin{array}{l}6-12 \\
\text { months }\end{array}$ \\
\hline 5 (a) & $\begin{array}{l}\text { Issue guidelines to facilitate mobile money as a low cost access } \\
\text { channel (initially for payments and savings only). Amend legislative } \\
\text { and regulatory framework, if necessary. }\end{array}$ & Medium & $\begin{array}{l}\text { Not } \\
\text { started }\end{array}$ & $\begin{array}{l}6-12 \\
\text { months }\end{array}$ \\
\hline 5 (b) & $\begin{array}{l}\text { Permit agent banking among financial institutions by allowing banks } \\
\text { to partner with local firms as banking agents. }\end{array}$ & Medium & $\begin{array}{l}\text { Not } \\
\text { started }\end{array}$ & \begin{tabular}{|l|}
$6-12$ \\
months
\end{tabular} \\
\hline 5 (c) & $\begin{array}{l}\text { Promote G2P and other bulk and recurrent payments, such as civil } \\
\text { service salaries, as an avenue to encourage consumers to utilize bank } \\
\text { accounts and to enhance competition in the banking sector. Promote } \\
\text { the use of digital financial services to facilitate these payments to } \\
\text { enhance financial inclusion. }\end{array}$ & Medium & $\begin{array}{l}\text { Not } \\
\text { started }\end{array}$ & $\begin{array}{l}9-18 \\
\text { months }\end{array}$ \\
\hline 6 (a) & $\begin{array}{l}\text { Conduct an enterprise survey to identify financing constraints for } \\
\text { businesses in order to promote access to finance for MSMEs. }\end{array}$ & Medium & $\begin{array}{l}\text { Not } \\
\text { started }\end{array}$ & \begin{tabular}{|l|}
$12-24$ \\
months
\end{tabular} \\
\hline 6 (b) & $\begin{array}{l}\text { Institute regulatory requirements that lenders consider a borrower's } \\
\text { capacity to repay and existing debts in loan decisions. }\end{array}$ & Medium & $\begin{array}{l}\text { Not } \\
\text { started }\end{array}$ & $\begin{array}{l}12-24 \\
\text { months }\end{array}$ \\
\hline 6 (c) & Review the functionality of mandatory auto insurance. & Low & $\begin{array}{l}\text { Not } \\
\text { started }\end{array}$ & $\begin{array}{l}6-60 \\
\text { months }\end{array}$ \\
\hline \multicolumn{5}{|c|}{ Strategic Area C: Upgrade Financial Infrastructure } \\
\hline No. & Recommendation & Priority & Status & Timeframe \\
\hline 7 & $\begin{array}{l}\text { Implement a fully interoperable card payment system with } \\
\text { international linkages following a diagnostic of current payments } \\
\text { infrastructure. }\end{array}$ & High & $\begin{array}{l}\text { Not } \\
\text { started }\end{array}$ & $\begin{array}{l}6-12 \\
\text { months }\end{array}$ \\
\hline 8 (a) & $\begin{array}{l}\text { Enhance existing credit registry with historical data, positive } \\
\text { information on clients, multi-borrowing/concentration statistics, } \\
\text { data from consumer lenders and the status of loans. }\end{array}$ & High & $\begin{array}{l}\text { Partially } \\
\text { started }\end{array}$ & $\begin{array}{l}6-12 \\
\text { months }\end{array}$ \\
\hline 8 (b) & $\begin{array}{l}\text { Research the potential impact of making data contributions } \\
\text { mandatory to the credit reporting system through discussions with } \\
\text { local stakeholders and studying this requirement in other countries. }\end{array}$ & Low & $\begin{array}{l}\text { Not } \\
\text { started }\end{array}$ & $\begin{array}{l}12-24 \\
\text { months }\end{array}$ \\
\hline $8(c)$ & $\begin{array}{l}\text { Implement a comprehensive legal framework for credit reporting and } \\
\text { a comprehensive credit information system (positive and negative), }\end{array}$ & Medium & $\begin{array}{l}\text { Partially } \\
\text { started }\end{array}$ & $\begin{array}{l}12-24 \\
\text { months }\end{array}$ \\
\hline
\end{tabular}




\begin{tabular}{|c|c|c|c|c|}
\hline & $\begin{array}{l}\text { which is available on all formal borrowers from banks, MFIs, payday } \\
\text { lenders and utilities. }\end{array}$ & & & \\
\hline 9 (a) & $\begin{array}{l}\text { Pass a modern legal framework for secured transactions and } \\
\text { electronic collateral registry in place. }\end{array}$ & High & $\begin{array}{l}\text { Not } \\
\text { started }\end{array}$ & $\begin{array}{l}6-12 \\
\text { months }\end{array}$ \\
\hline 9 (b) & $\begin{array}{l}\text { Implement an electronic movable and immovable collateral registry } \\
\text { by creating a modern secured transactions law. }\end{array}$ & Medium & $\begin{array}{l}\text { Not } \\
\text { started }\end{array}$ & $\begin{array}{l}6-12 \\
\text { months }\end{array}$ \\
\hline 9 (c) & $\begin{array}{l}\text { Train businesses and lenders on suitable collateral guarantees and } \\
\text { the secured transaction law once it passes. }\end{array}$ & Medium & $\begin{array}{l}\text { Not } \\
\text { started }\end{array}$ & $\begin{array}{l}9-18 \\
\text { months }\end{array}$ \\
\hline 10 & $\begin{array}{l}\text { In the context of government borrowing needs, explore the } \\
\text { development of government bonds and their linkages to monetary } \\
\text { policy through dialogue with government stakeholder. }\end{array}$ & Low & $\begin{array}{l}\text { Not } \\
\text { started }\end{array}$ & $\begin{array}{l}12-24 \\
\text { months }\end{array}$ \\
\hline \multicolumn{5}{|c|}{ Strategic Area D: General Financial Sector } \\
\hline No. & Recommendation & Priority & Status & $\begin{array}{l}\text { Timefram } \\
e\end{array}$ \\
\hline \multirow{2}{*}{$11(\mathrm{a})$} & $\begin{array}{l}\text { Revise the judicial review process for commercial and financial } \\
\text { transactions, including execution of collateral guarantees and } \\
\text { registration of collateral. }\end{array}$ & High & $\begin{array}{l}\text { Not } \\
\text { started }\end{array}$ & $\begin{array}{l}6-12 \\
\text { months }\end{array}$ \\
\hline & $\begin{array}{l}\text { Train judges on commercial and financial adjudication techniques. } \\
\text { Streamline adjudication for small claims. Institute alternative dispute } \\
\text { resolution mechanisms and arbitration. }\end{array}$ & Medium & $\begin{array}{l}\text { Not } \\
\text { started }\end{array}$ & $\begin{array}{l}6-12 \\
\text { months }\end{array}$ \\
\hline 12 (a) & $\begin{array}{l}\text { Develop strong auditing and accounting infrastructure and standards } \\
\text { by establishing OTOCA (professional accountancy organization), } \\
\text { creating legislation stipulating auditing standards, and updating chart } \\
\text { of accounts. }\end{array}$ & Medium & $\begin{array}{l}\text { Not } \\
\text { started }\end{array}$ & $\begin{array}{l}6-12 \\
\text { months }\end{array}$ \\
\hline 12 (b) & $\begin{array}{l}\text { Task OTOCA to train MSMEs on accounting and finance statement } \\
\text { preparation. }\end{array}$ & Medium & $\begin{array}{l}\text { Not } \\
\text { started }\end{array}$ & $\begin{array}{l}6-12 \\
\text { months }\end{array}$ \\
\hline 13 & $\begin{array}{l}\text { Explore potential for further cooperation with Portuguese-speaking } \\
\text { countries on the various recommendations, including assessing the } \\
\text { compatibility and feasibility of adopting effective laws, practices, and } \\
\text { systems from Lusophone countries. }\end{array}$ & High & $\begin{array}{l}\text { Not } \\
\text { started }\end{array}$ & $\begin{array}{l}1-6 \\
\text { months }\end{array}$ \\
\hline
\end{tabular}




\section{Introduction}

\section{a. Country Context}

1. Located approximately 350 kilometers off the western equatorial coast of Central Africa, São Tomé and Príncipe (STP) is one of the smallest countries in Sub-Saharan Africa with a primarily Portuguese speaking population of 197,900 . STP is comprised of two main islands and four islets, which have a total landmass of 1,000 square kilometers.

2. With a per capita income of USD $\$ 1,811$ in 2014 , STP is a lower middle-income country that performs higher than the sub-Saharan average in the United Nations Human Development Index. It has also made important strides in key social indicators, including achieving near universal primary school enrollment, a life expectancy of over 66 years, and an infant mortality rate of less than five per 49 live births.

3. Despite these achievements, São Tomé and Príncipe faces a number of critical challenges. Approximately 62 percent of its population lives in poverty, it has limited resources, its export base consists primarily of a single commodity (cocoa) and a developing tourism industry, and it is highly dependent on external support with 80 percent of its budget financed by development partners.

4. Approximately 90 percent of agricultural exports are cocoa. As a result, the country is vulnerable to international commodity price shocks and climate change. Lower prices not only affect farmers, but they also negatively affect banks exposed to the cocoa sector. Furthermore, the capacity to repay external debt is reduced by the decline in commodity prices as foreign exchange reserves decrease.

5. The discovery of oil in the 2000's resulted in an influx of capital and new entrants to the banking sector. Foreign direct investment increased from 3.3 to 41.7 percent of GDP between 2004 and 2008, and the banking sector grew rapidly (spurred by liberalization in the sector) with the number of markets participants going from 1 to 6 banks during that period. This influx of capital also contributed to inflation, which increased from 13.3 percent in 2004 to 32 percent in 2008.

6. As the prospects of commercially viable oil diminished, FDI fell to about 8 percent in 2014 . The real GDP growth rate almost halved from 8.2 to 4.5 between 2008 and 2014 and private sector credit to GDP fell from 40 percent in 2010 to 28.3 percent in 2014. 


\section{b. Recent Macroeconomic Developments}

7. The economy grew 4.5 percent in 2014 in line with the sub-Saharan African growth rate of 4.3 percent. Slow growth in advanced markets, particularly Europe, could further reduce demand for exports and tourism, aid, and investment.

8. GDP growth averaged 5 percent between 2001 and 2014, keeping it above that of sub-Saharan Africa (4.8 percent), small states in sub-Saharan Africa (4.3 percent), and small states (3.5 percent) averages. Since 2009, GDP growth has begun to slow down. Despite strong growth in GDP and GDP per capita, two-thirds of the country's population lives in poverty.

Figure 1: GDP and GDP per Capita Annual Growth
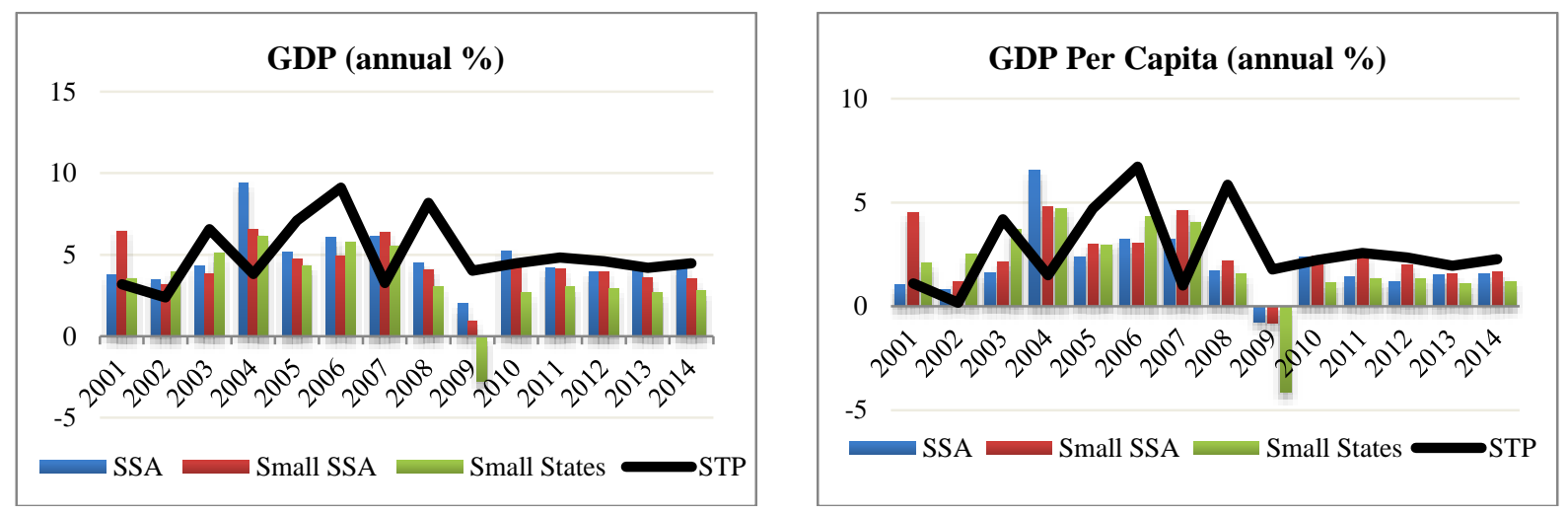

Source: World Development Indicators

Note: SSA = Sub-Saharan Africa and Small SSA = small states in Sub-Saharan Africa, including island nations.

9. São Tomé and Príncipe's economy is heavily dependent on services, which comprise 66 percent of GDP with the remainder comprised of agriculture (22 percent) and industry \& manufacturing (12 percent). In 2012, services accounted for 46.9 percent of employment, while agriculture accounted for 26.1 percent and industry 21.4 percent of employed. ${ }^{4}$

10. Foreign direct investment to São Tomé and Príncipe averaged 13.5 percent of GDP from 2001 to 2013 , but with wide oscillations year-to-year. Offshore oil discoveries drove FDI up to 41.7 percent of GDP in 2008, which fell to a low of 1.9 percent in 2013 as investment in the oil sector receded. The FDI trend in sub-Saharan Africa, small states in sub-Saharan Africa, and small states has been much more consistent than in STP. Inflation is historically high in STP, averaging 22.9 percent from 2007 to 2009. However, since pegging its currency to the Euro, inflation has been falling year after year to reach the historical low of 4 percent in 2015. The Inflation differential between STP and the Euro area has produced a real exchange rate appreciation. This, however,

\footnotetext{
${ }^{4}$ At present, there is no Enterprise Survey or other reliable date on the number of MSMEs and their challenges with access to finance in STP.
} 
has not significantly impacted STP's external competitiveness due to its narrow export base concentrated on commodities and niche markets.

Figure 2: NDI Inflows and Inflation
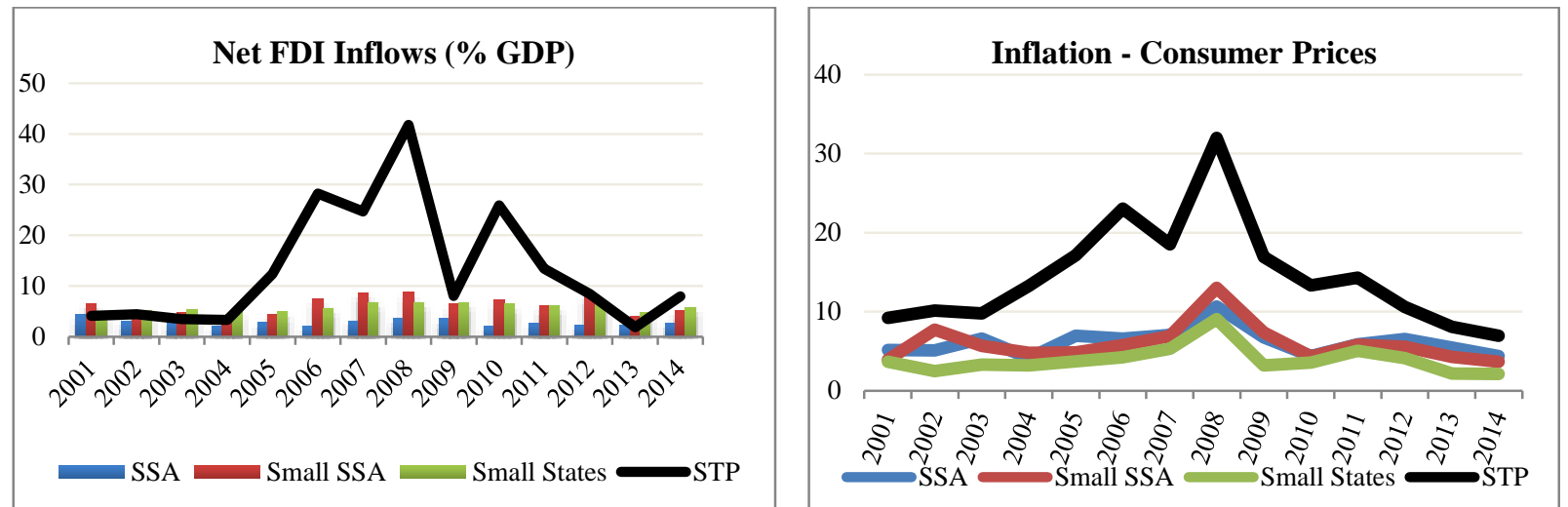

Source: World Development Indicators

Note: SSA = Sub-Saharan Africa and Small SSA = small states in Sub-Saharan Africa, including island nations.

11. Not only is São Tomé and Príncipe's economy vulnerable to massive FDI inflows, outflows, and fluctuations due to the prospects of oil, but it is also highly exposed to changes in global commodity prices, particularly cocoa and oil. As noted above, STP's export base is primarily cocoa, meaning significant changes to the price of cocoa have large financial implications for the country. In terms of the exposure to fluctuations in oil prices, the key issue is that the home markets of the foreign banks that operate in STP and which partially own BISTP, are all oileconomies. As a result, changes in the price of oil (see chart below) have large consequences for net FDI flows. For example, when the price of oil crashed during the 2008 global recession (see chart below), FDI plummeted. This exposure is particularly concerning considering that commercial banks control 98 percent of the financial sector's assets.

Figure 3: Price of Crude Oil

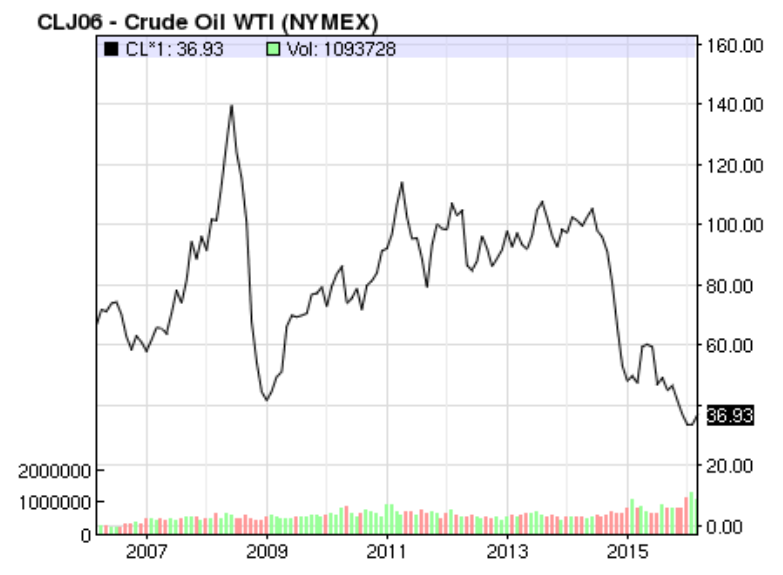


12. Remittances to São Tomé and Príncipe have increased significantly in recent years. In 2009, remittances made up just over one percent of GDP and reached a high of 8.7 percent in 2013. As a result, STP's average remittances rate of 2.6 percent of GDP for the period of 2001 to 2014 surpassed the sub-Saharan African average of 2.4 percent. In aggregate terms, Sao Tome and Principe received USD \$26.8 million in international remittances in 2014 equivalent to 8.1 percent of GDP. While small in aggregate terms, as remittances grow and if properly harnessed, they have the potential to increase financial inclusion by promoting stimulating demand for savings accounts and to increase the resource base of firms, as is the case in countries such as Cape Verde and Morocco.

Figure 4: Remittances Received

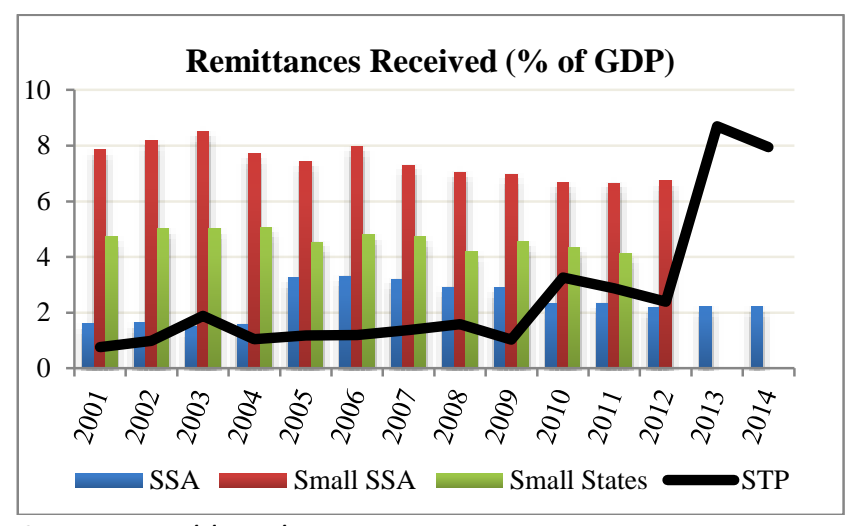

Source: World Bank

13. Given these challenges, São Tomé and Príncipe's Cabinet approved the second Poverty Reduction Strategy Paper (PRSP-II) in July 2012. The PRSP-II is the successor to the Government's previous development strategy, the PRSP-I, and furthers the country's commitment to promoting sustainable poverty reduction through broad-based growth. PRSP-II focuses on four key areas: 1) promoting good governance and public sector reform, 2) supporting sustainable development and extending basic social services, 3) enhancing human capital and social service delivery, and 4) strengthening social cohesion and social protection. PRSP-Ils efforts are continued in the Government's comprehensive reform agenda, called "2016-2018 National Strategy Document" (NSD). NSD has the same four key objectives as PRSP-II.

14. Recognizing the challenges specific to financial sector development, the Government of São Tomé and Príncipe requested assistance from the World Bank and FIRST Initiative in developing a coordinated, prioritized and well-sequenced roadmap for developing its financial sector; which is in line with the broader economic reform agenda discussed in PRSP-II. The FSDIP provides a roadmap in key policy areas for financial sector development, particularly in the areas of strengthening financial sector soundness, inclusion and infrastructure.

15. Developing an effective national financial system can be a challenge for small countries and island nations due to an array of factors unique to their context, such as the size of the financial sector. To overcome issues relating to the economies of scale and others, some countries choose 
to create regional linkages, such as with currencies and national payment systems. Although, integration is an important topic, it is not the focus at this early stage in São Tomé and Príncipe's financial sector development, but it will be an important one to review as the sector develops. That said, it is important to explore the possibility of building upon regional or Lusophone approaches to financial sector development, such as the compatibility and feasibility of adopting effective laws and practices, so as to ensure best practices are informed by the local context and lessons learned from other countries. Furthermore, given the extent of cooperation with Lusophone countries like Brazil and Portugal, there is also a need to assess the potential for further cooperation on implementing the FSDIP's recommendations.

\section{c. FSDIP Objectives}

16. The overall objective of the FSDIP is to establish a framework for the development of São Tomé and Príncipe's financial sector and provide the Government and private sector stakeholders with a clear roadmap to sequence reforms in financial policy. The expected outcome is a more sound, efficient and inclusive financial sector achieved by a series of reforms and interventions implemented by the Government and relevant financial sector authorities based on a coherent policy view. The ultimate goal is to increase the contribution of the financial sector to the reduction of poverty and promotion of shared prosperity in São Tomé and Príncipe.

17. Specifically, the vision for financial sector development in São Tomé and Príncipe is that of a stable, competitive and inclusive financial system that provides access to affordable quality financial services based on healthy competition among strong financial institutions capable of providing diverse and appropriate services and products. A competitive financial sector increases the provision of credit and lowers costs and an inclusive financial sector increases access to finance for smaller enterprises and low-income households.

18. A stable, competitive, and inclusive financial system is an essential precondition to long-term growth. A stable financial sector is necessary to promote long-term investor confidence, the free flow of credit to the private sector and sustained FDI flows to finance long-term growth. A competitive market ensures access to affordable and consumer-demanded financial services, which are long-term in nature and can more easily adapt to innovations in the sector. Furthermore, increasing access to credit is critical to ensuring that MSMEs have the requisite resources to invest in their enterprises, without which growth will continue to be highly susceptible to massive fluctuations in FDI and commodity prices.

19. The FSDIP is organized around four themes, which were discussed with the Government, Central Bank, private sector stakeholders, and civil society and is documented in a series of background notes prepared by the World Bank. ${ }^{5}$ The first theme supports a modern legal and

\footnotetext{
${ }^{5}$ At the request of Governor of the Central Bank of São Tomé and Príncipe, FSDIP focuses on measures to upgrade the legal and regulatory framework related to the financial sector. Given the size of the domestic banking sector, the primary focus of this implementation plan is on reforms to the banking system and financial infrastructure.
} 
regulatory framework that establishes clear rules and boundaries for financial market participants, including mechanisms for entry and exit. A modern legal and regulatory framework contributes to the second theme: a sound and stable financial system supervised by capable and competent authorities. This contributes to the third theme, which is a robust and efficient financial infrastructure that reduces information asymmetries by providing timely and accurate data on credit and collateral usage in order to allow for appropriate risk management and credit allocation. Together these three themes contribute to the fourth theme of broadening the quality and affordability of financial services available to individuals and enterprises, particularly MSMEs and low-income households as outlined in the figure below.

Figure 5: Building Blocks of Financial Sector Development in São Tomé and Príncipe

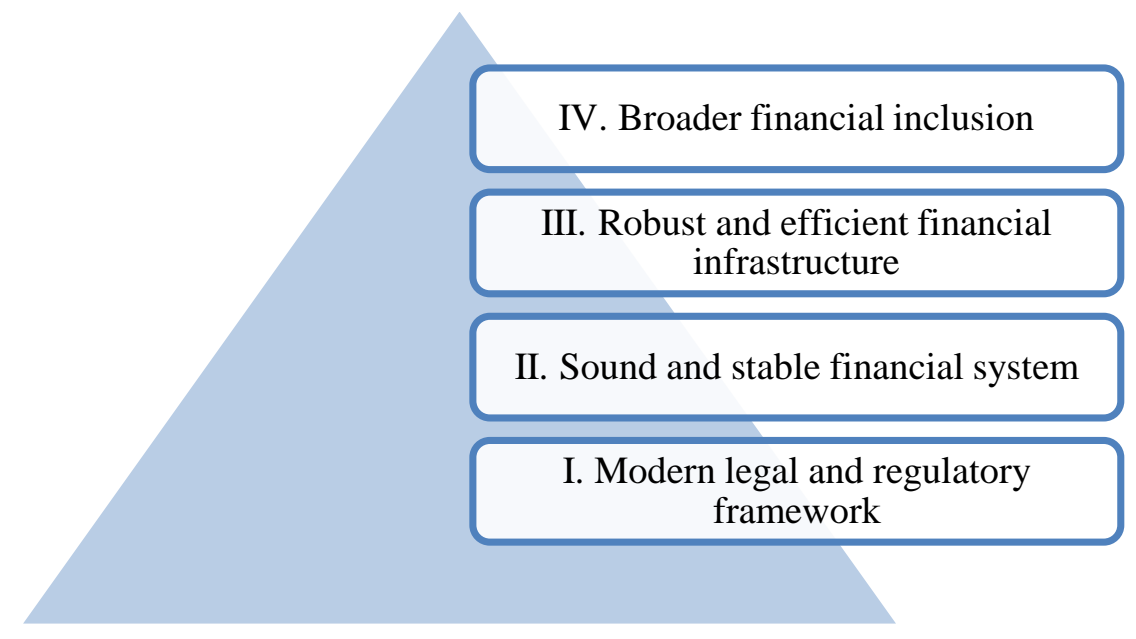




\section{Financial Sector Context}

20. São Tomé and Príncipe is one of the smallest independent financial systems in the world. Total banking sector assets were 4.7 trillion dobras (USD 214 million) in 2015 equivalent to 77 percent of GDP, up from 26 percent of GDP in 2001. The financial sector is comprised of seven commercial banks with 98 percent of financial sector assets, two insurance firms that specialize in property and casualty business and four small consumer lenders.

21. Following independence from Portugal in 1975 until 1993, only one bank, Banco Nacional de São Tomé e Príncipe (BNSTP), operated in the country as an agency within a centrally directed economy where the state owned or controlled most of the means of production. In 1993, the Government divided BNSTP into the Banco Central de São Tomé e Príncipe (BCSTP), responsible for monetary and regulatory functions, and the BISTP, for commercial banking.

22. Government liberalization of the banking sector in the early 2000s led to three new market entrants in 2004 and the potential for offshore oil attracted four additional banks from nearby Angola, Cameron, and Gabon by 2008. Afriland Bank from Cameroon entered the market in 2003 followed by Banco Equador and National Investment Bank in 2004, Commercial Bank in 2005, Ecobank in 2007, Oceanic Bank from Nigeria in 2008 (Energy Bank after 2011), Island Bank in 2010, and BGFI from Gabon in 2012.

23. The rapid expansion of the banking sector proved to be a challenge for the central bank, which did not have in place the systems or staff to review requests for licensing and authorizations of new banks as well as effective supervision of the industry. The central bank's decision to place three banks under administration within a decade of granting their license underscores some of the weaknesses in the initial licensing and subsequent supervision.

24. Although, the number of banks operating in the system increased rapidly in a short period, this did not result in a significant shift in market shares. The largest bank, BISTP, is market dominant with approximately two-thirds of total deposits and half of total assets. BISTP also has the largest branch network (half of total branches) and holds 70 percent of all foreign currency deposits, which provides them with a distinct advantage in servicing clients requiring foreign currency to finance imports. ${ }^{6}$ Together, these factors have important implications for market competitiveness. BISTP is primarily owned by the Government (48 percent) followed by Caixa Geral de Depósitos in Portugal (27 percent) and Banco Africano de Investimentos in Angola (25 percent). There are, however, discussions of the Government selling off its shares in BISTP. All other banks are foreign owned (see: Summary of Banking System table below).

\footnotetext{
${ }^{6}$ Foreign currency deposits make up 40 percent of all deposits in the banking system.
} 
Table 2: Summary of Banking System in São Tomé and Príncipe as of December 2015

\begin{tabular}{|c|c|c|c|c|c|c|c|c|c|}
\hline$\#$ & Bank & $\begin{array}{l}\text { Assets - } \\
\text { USD, } \\
\text { millions }\end{array}$ & $\begin{array}{l}\text { Deposit } \\
\text { Market } \\
\text { Share } \\
(\%)\end{array}$ & $\begin{array}{l}\text { Loans } \\
\text { to } \\
\text { Assets } \\
(\%) \\
\end{array}$ & Branches & Clients & $\begin{array}{l}\text { Domestic } \\
\text { ownership }\end{array}$ & $\begin{array}{l}\text { Foreign } \\
\text { ownership }\end{array}$ & $\begin{array}{l}\text { Country of } \\
\text { origin of } \\
\text { foreign } \\
\text { shareholders }\end{array}$ \\
\hline 1 & BISTP & 107 & 62.7 & 27.2 & 12 & 50,000 & 48 & 42 & $\begin{array}{l}\text { Angola, } \\
\text { Portugal }\end{array}$ \\
\hline 2 & Afriland & 30 & 8.9 & 56.8 & 2 & 6,000 & - & 100 & Cameroon \\
\hline 3 & Equador & 17 & 15 & 55.9 & 4 & 11,000 & 5 & 95 & Angola \\
\hline 4 & Energy & 25 & 2.1 & 4.1 & 5 & 15,000 & - & 100 & $\begin{array}{l}\text { Ghana, } \\
\text { Nigeria }\end{array}$ \\
\hline 5 & Ecobank & 14 & 4.4 & 26.8 & 1 & 4,000 & - & 100 & $\begin{array}{l}\text { Ghana, } \\
\text { Nigeria, Côte } \\
\text { d'Ivoire }\end{array}$ \\
\hline 6 & BGFI & 15 & 4.3 & 12.5 & 1 & 80 & - & 100 & Gabon \\
\hline \multirow[t]{2}{*}{7} & COBSTP & 10 & 2.7 & 43.3 & 1 & 4,000 & - & 100 & Cameroon \\
\hline & Total & 218 & 100 & 33.6 & 26 & 90,080 & & & \\
\hline
\end{tabular}

Source: BCSTP

25. The sector began to consolidate in 2014 when Energy Bank assumed control of Island Bank (both predominately owned by shareholders from Nigeria). Most market participants and observers expect further consolidation or market exits over the coming years due to low oil prices, the small size of the financial sector, and the financial position of some of the foreign banks.

26. The sector is highly concentrated, which is typical of small financial systems and presents certain unique challenges. ${ }^{7}$ The provision of financial services is often more expensive and more limited in small financial systems compared to larger ones. Small financial systems lack economies of scale. As many costs in the provision of financial services are essentially fixed, fewer transactions and fewer customers make it more expensive for financial institutions to operate as they face a number of costs including branch network, computer systems, and corporate governance structures that are largely independent of the number of customer served. Similarly, the costs of regulating and supervising a financial system and the cost of payments systems and other financial infrastructure are also largely independent of the number of institutions that make up the financial system. Moreover, it is often difficult for small financial system to diversify risk, which can further constrain the size of the financial system in small markets and contribute to financial stability risks (for additional discussion on this topic, see: Small Financial Systems Annex).

\footnotetext{
${ }^{7}$ See "Coping with a Small Financial System: Policy Issues for Africa", Bossone \& Honohan, 2003.
} 
Figure 6: Market Share by Assets, Deposits and Loans, October 2015
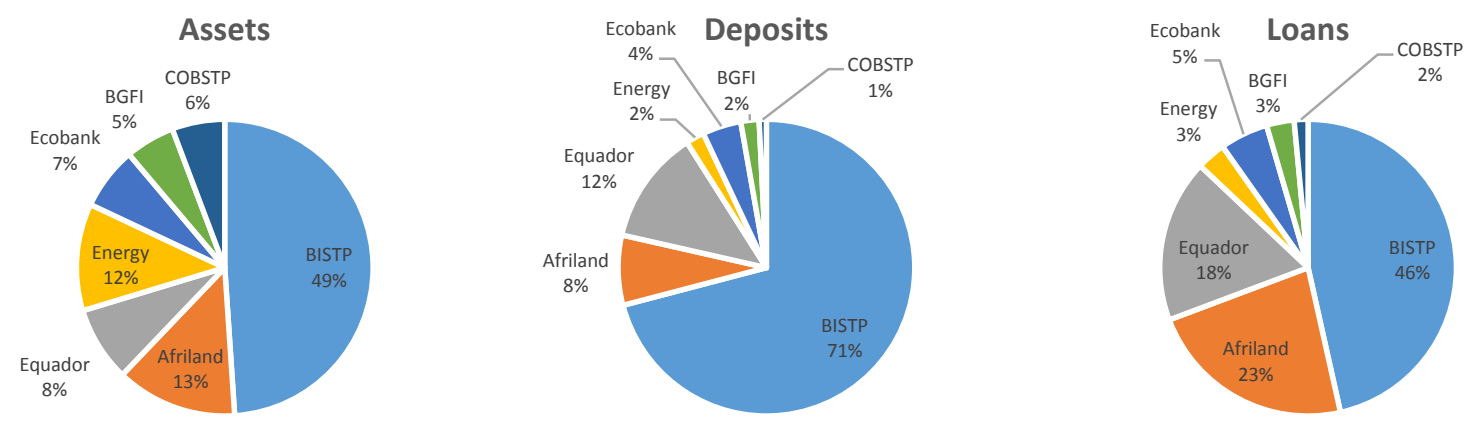

Source: BCSTP

27. Private sector credit to GDP in São Tomé and Príncipe fell from a peak of 40 percent in 2010 to 28.3 percent in 2014, paralleling a decline through Sub-Saharan Africa (58.3 to 51.7). Conversely, from 2010-2014 private sector credit to GDP increased from 35.6 to 37.7 in small states and 31.6 to 35.5 in SSA small states. From 2001 to 2014 private sector credit to GDP averages 25.6 percent in São Tomé and Príncipe, 59.9 percent in SSA, 27.3 percent in SSA small states, and 34.6 in small states (see: annex on Small Financial Systems). Relative to a sample of peer countries, São Tomé e Príncipe has a high spread between its lending and deposit rates in banks (13.3 percentage points) and more banks in its market.

28. The decrease in credit is due a confluence of factors that largely stem from the prospects of commercially viable oil diminishing, which saw FDI decrease from a high of 41.7 percent of GDP in 2008 to 8 percent in 2014. As a result, the economy began to slow, with real GDP growth rate almost halving from 8.2 to 4.5 between 2008 and 2014. At the same time, NPLs have increased from 15.6 in 2011 to 29.8 in 2015 and provisions as a percentage of NPLs increased from 77 percent in 2014 to 90 percent in 2015

Figure 7: Private Credit to GDP and Interest Rate Spreads, Select Countries

Domestic Credit to Private Sector (\% of GDP)

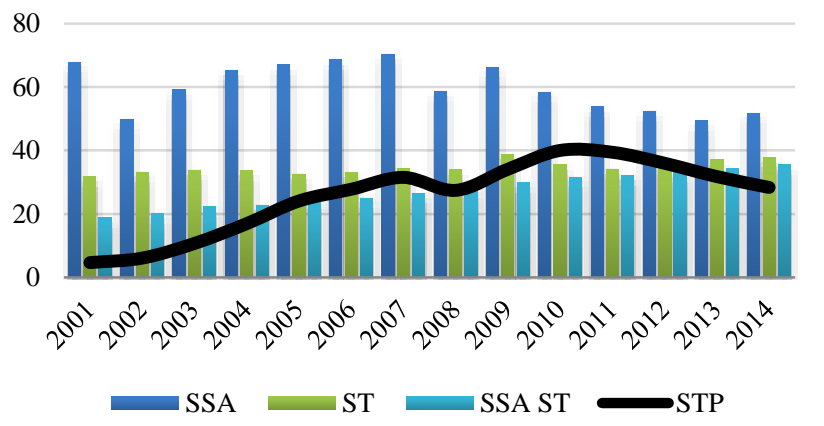

Spread: Lending - Deposit Rates (\%)

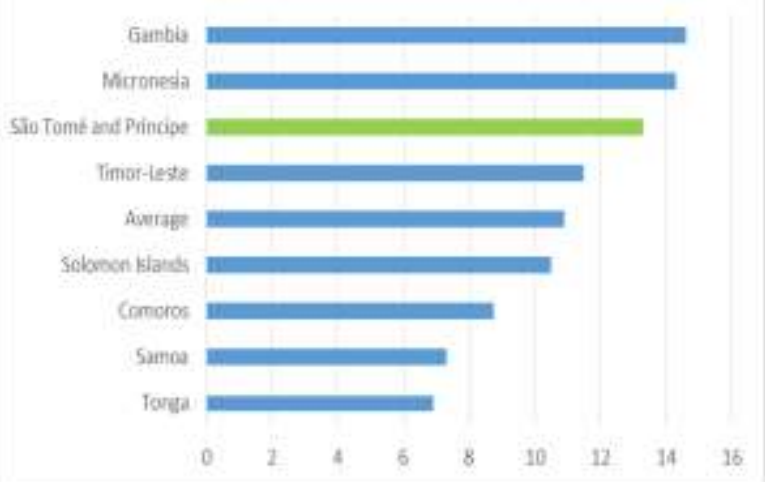

Source: World Bank and IMF (interest rate spread data is 2013) 
29. As of September 2015, gross credit was valued 1.9 trillion dobras (USD 84.6 million), which is a 4.8 percent decrease from 2011 when gross credit was 1.8 trillion dobras (USD 80.8 million). ${ }^{8}$ At the same time, non-performing loans have increased by 68 percent from 278 billion dobras (USD \$12.6 million) in 2011 to 571 billion dobras (USD 26 million) in 2015.

30. Some of the key sectors that contribute the most to domestic GDP growth could potentially benefit from additional loans. There is currently no demand-side survey on the banking sector, so ascertaining the demand for existing and prospective financial products is difficult to assess. Traditional sectors such as construction, with assets to pledge as collateral, receive more domestic credit than sectors such as agriculture, which experiences seasonal credit demands and operates on Government-owned land.

Figure 8: Credit by sector (2011-2015)

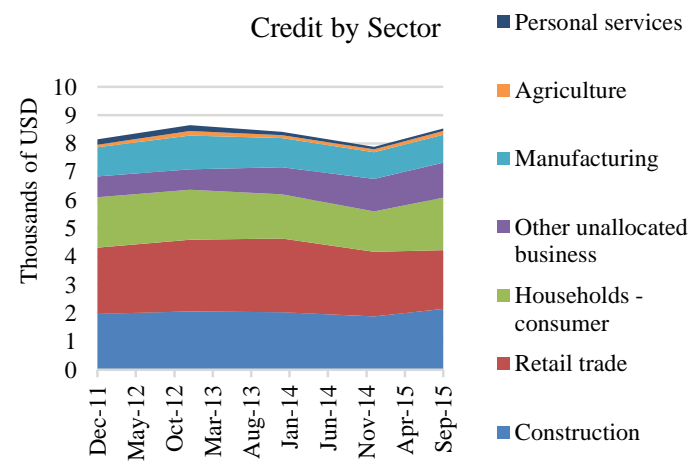

Source: BCSTP

31. The market in Government securities commenced in January 2015 with a debut issuance of USD 3 million. The six-month bonds, purchased by three banks, yield 6.2 percent equivalent to 100-250 basis points spread over interest paid on savings accounts. With this issuance, the Government seeks to create an interbank market of tradable securities available to serve as guarantees for short-term loans.

\section{a. Soundness and Stability}

32. The largest bank in the economy, BISTP, is robust but there is a high potential for distress as evidenced by the three banks that the central bank has placed under administration since 2010. ${ }^{9}$ End-2015 data shows a combination of negative profitability (ROA: negative 5.2 percent, ROE negative 27 percent), high non-performing loan rate (NPL: 29.8 percent) and a decline in capital adequacy (two banks have CARs below the central bank minimum of 12 percent), all of which are

\footnotetext{
8 BCSTP

9 BCSTP has intervened in three banks: Commercial Bank in 2010, Island Bank in 2013, and Equador Bank in 2015. National Investment Bank effectively ceased operations in 2006 and BCSTP cancelled its license due to inactivity in in 2011. Energy Bank acquired Oceanic Bank in 2011 with BCSTP approval. The significant number of short-lived operations of new entrants in the banking sector in São Tomé and Príncipe raises the question as to whether all the banks have been appropriate from the outset.
} 
key risks to financial stability. The position of these banks and the rapid manner in which they entered the market also merit a review of the banking licensing procedures to ensure new market entrants do not jeopardize the stability of the financial sector.

33. BCSTP placed the third largest lender (Banco Equador) under administration in January 2015 for repeatedly failing to meet minimum capital requirements. ${ }^{10}$ This is a more complex resolution challenge than when BCSTP intervened in one of the smallest banks (Island Bank) in 2013 after it failed to comply with supervisory requirements and arranged its sale to a competitor. ${ }^{11}$ BCSTP also attempted to resolve another bank in 2010, but shareholders were able to successfully contest the resolution actions in court and reverse the decision.

34. The experience in resolving these three banks led BCSTP to reassess its resolution powers and authorities. BCSTP requested technical assistance from the IMF to draft a new Bank Resolution Law, which Parliament is considering for approval. In addition, BCSTP has directed three banks to raise their capital above the minimum required to operate by end-December 2015 (see: annex on Select Financial Soundness Indicators). These issues also highlight the importance of conducting an annual financial stability report, which would include an analysis of overindebtedness.

35. São Tomé and Príncipe faces a challenge in developing and regulating a financial market that can serve the broader financial services needs for the economy and maintain an international standard for the breadth and robustness of regulation and supervision. BCSTP's technical expertise and productivity provide it the capacity to be an effective supervisor in certain areas by international standards, e.g., the production of their internally developed credit registry. BCSTP has also benefited from technical assistance from credible partners, notably the IMF, Bank of Portugal and the Central Bank of Brazil. Nevertheless, on-site supervision of financial institutions is infrequent and corrective actions and enforcement often occur with significant delays.

36. Structural issues limit the scope of financial sector development in São Tomé and Príncipe. The size and advantage of the largest bank (handling government salary payments, access to foreign exchange, and limit future credit to borrowers that do not repay) may be leading to market practices that are inefficient and make the market unprofitable for smaller rivals. The limited investment horizon leads entities like the national pension fund to make investments that do not discriminate in terms of quality, time profile, or return requirements, which reduces the pressure on market participants to perform.

37. Minimum capital requirements are 12 percent of risk-weighted assets, which is above international standards and practice in many countries although in practice only three quarters of banks have been able to achieve this standard since 2013 (see: annex on Select Financial Soundness Indicators, 2011-2015). The average capital to risk-weight assets for the banking sector is 24.1 percent in December 2015, but there is significant variability among banks.

\footnotetext{
${ }^{10}$ Banco Equador held 12.5 percent of total deposits (the second largest share) at the time of intervention and its primary term depositors are the national oil importation company and the national pension.

11 Island Bank held 1 percent of total deposits at the point of intervention.
} 


\section{b. Performance}

38. The interest rate spread between what banks charge for loans and what they offer to depositors is high relative to the Sub-Saharan average, small states in Sub-Saharan African and small economies, but it is also decreasing (see figure below). The interest rate spread must also be seen in light of the high NPL rate. The cost of intermediation in São Tomé and Príncipe has improved, particularly since the Government pegged the currency to the Euro in 2010. Nevertheless, interest rate spreads (12.5 percent in 2014) continue to be well in excess of comparable country groups such as small Sub-Saharan Africa states (8.02 percent in 2014), Caribbean small states (7.1 percent in 2014), and the average in sub-Saharan Africa (8.6 in 2012 percent). In terms of what customers actually pay in interest, banks charge 23 percent on loans. ${ }^{12}$ This limits the willingness of firms to finance growth and consumers attitudes towards financial services.

Figure 9: Interest Rate Spread Comparison, Select Countries, 2001-2014

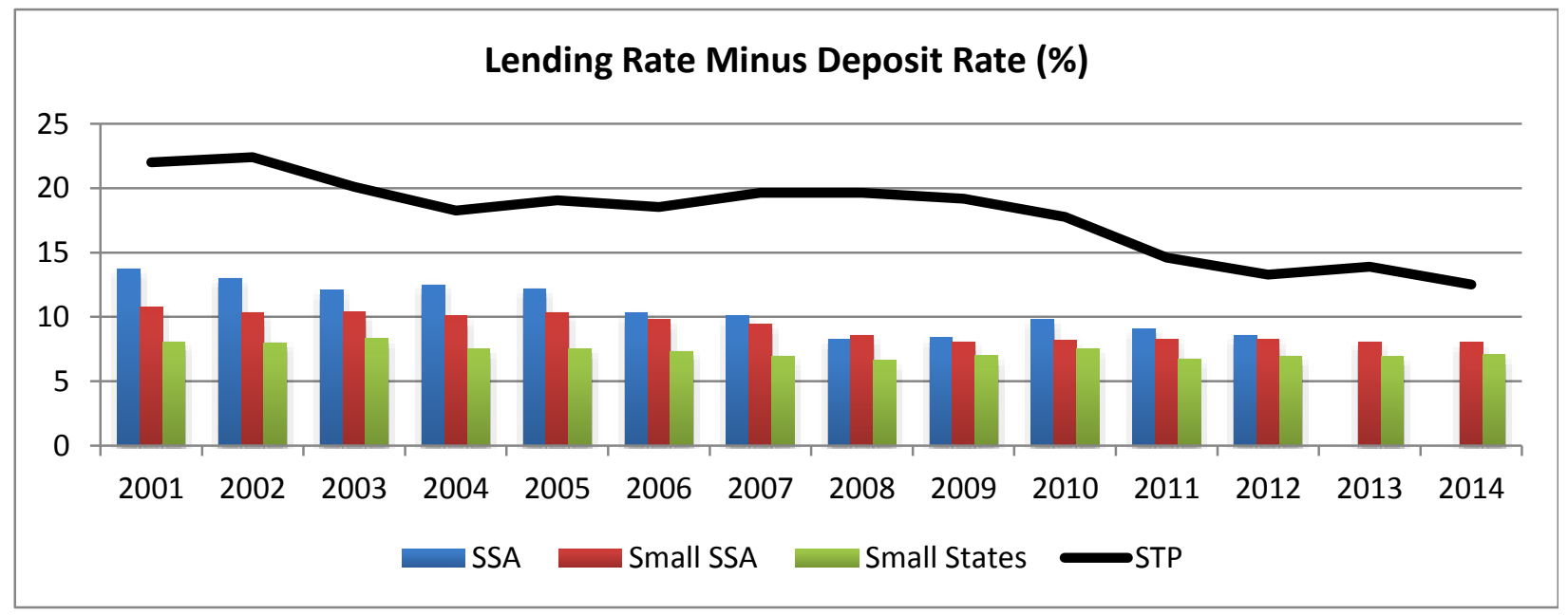

Source: World Bank

39. Sector wide returns on assets and equity were negative 5.2 percent and negative 27.1 percent respectively as of December 2015, which is worse than the average returns for 2011 to 2014 (ROA: negative 1.4 percent; ROE: negative 6.75 percent). This is due to the cost of increased provisioning against non-performing assets as a number of banks entered the market in hopes of oil discoveries that never materialized. ${ }^{13}$ Negative returns are also a result of the high cost of funds for some of the smaller banks. In contrast to most banks in the market that are losing money, the largest bank had a positive return on assets, which was high by international standards.

\footnotetext{
12 BCSTP website

${ }^{13}$ NPLs have been high for years and ranged between 16 and 44 percent from 2006-2014 according to BCSTP.
} 
40. Smaller banks generally are not profitable but the largest payday lender, Credial is profitable (ROA: 0.7 percent; ROE 2.4 percent). Despite having a self-reported NPL rate of 35 percent, Credial is able to generate a profit (albeit not a real rate or return considering inflation). ${ }^{14}$ This is the result of having low operating costs, zero marginal cost of funds as its only lending its own funds and interest rates, which are three to four times what banks charge. Interest rates charged by the largest payday lender are 50 to 75 percent per year compared to 23 percent at banks. ${ }^{15}$

41. Another indicator of the efficiency of the banking sector is its ability to transform savings into loans (the loan to deposit ratio). In São Tomé and Príncipe, the overall trend has shown that while deposits continue to increase, lending has fallen and the transformation ratio has subsequently declined from 119.5 percent in 2011 to 68.3 percent in 2015. São Tomé and Príncipe's transformation ratio is characteristic of other small countries in Africa and around the world. The trend, which is likely due to increases in non-performing assets and accumulated losses (i.e., NPL rate of 24.9), a decline in private-sector credit, and economic growth slowing, continues to show a decline reflecting the fall in investments in credit operations. At the same time, there has been a rise in deposits, which also reinforces the importance of financial sector soundness. To that end, the central bank is also exploring the feasibility and requirements for implementing a deposit insurance scheme. Deposit insurance, which is an important feature of the overall financial safety net, is uncommon in small financial systems, particularly those characterized by a high degree of concentration.

\section{c. Liquidity}

42. Liquidity in the banking system is high due to slow credit growth, the increase in nonperforming assets, and the absence of liquidity management tools. This is evident in the liquid assets to total assets ratio of 52 percent and the liquid assets to short term liabilities ratio of 73 percent in December 2015. Furthermore, the IMF estimates that excess liquidity in the financial system is 24 percent of deposits or 5 percent of GDP. It is distributed asymmetrically among banks, with the majority of liquidity concentrated in the largest bank, while two banks struggle to meet the minimum required reserve levels. Excess liquidity has built up mainly from net inflows and despite NPLs partially leveling off (but still relatively high from past years), banks continued to decrease the amount they allocate to their credit portfolios. This has had the net effect of increasing liquidity levels in banks as is evident in the liquid assets to total assets ratio increasing from 20 to 52 percent between 2011 and 2015, and the liquid assets to short term liabilities ratio increasing from 37 to 73 percent. Additionally, as highlighted in the previous section the transformation ratio has decreased significantly, which contributes to the decreasing loans to total liabilities ratio from 83 percent in 2011 to 46 percent in 2015 . The persistence of excess liquidity in the system indicates that it may have become a structural feature of the banking sector. In addition, there only a few local investment options, as domestically issued

\footnotetext{
14 Payday lenders and microfinance institutions are not regulated and do not file any prudential returns.

15 Information based on field interview with Credial in July 2015 and BCSTP website.
} 
securities are limited and have only been available since January 2015 and excess reserves at the central bank generate no interest.

43. The limited depth of the domestically issued securities market contributes to the challenge of managing liquidity as well as cash management for the national pension fund and banks, which are subject to a 30 percent reserve requirement. An important obstacle for the development of long-term financing in Sao Tome is the absence of capital markets. While Sao Tome may not need fully-fledged capital markets, having an established Government securities market is nevertheless an important feature of its long-term development.

44. Development of a domestic debt market will also reduce the Government's reliance on external concessional financing, which currently contributes 80 percent of the budget. Moreover, excess liquidity and the absence of viable investment options increases financial institution demand for government securities. Domestic debt markets also perform an essential function, such as a benchmarking prices and providing a risk-hedging instrument, which facilitates the development of corporate bond markets, housing finance, and long-term finance. Government securities are the foundation of most fixed-income markets in developed and developing countries. Additionally, deep and liquid money and debt markets are important for monetary stability and greater financial intermediation. Although, economic context implies the development of a small and limited government bond market, nonetheless its development is crucial to the reduction of the Government's reliance on external concessional financing, providing a risk-hedging instrument, and promoting the benchmarking of prices, monetary stability and greater financial intermediation.

45. The Government is aware of the importance of developing the domestic debt market for both public debt management and financial sector development purposes and has undertaken a number of reforms in this area. Among those is the adoption of a Medium Term Debt Strategy (MTDS), which covered the period until 2015 by the Cabinet following a new legislative framework for debt operations and the publishing of debt data in budget documents. In July 2015, the Treasury issued the first T-bills, called Bilhetes do Tesouro (BT). The first bills were intended to smooth Government consumption patterns and relieve cyclical revenue shortfalls. The interest rate offered was 6.2 percent annually. The BTs represents an opportunity for the central bank to influence the market interest rate, since currently the benchmark interest rate set by the BCSTP has served more as an indicative price rather than the primary cost of money. However, to fully benefit from these reforms much additional work remains to be done, particularly efforts to improve debt reporting and monitoring, T-Bill auction and pricing mechanisms, and regularly updating and implementing the debt management strategy.

\section{d. Asset Quality and Loan Classification}

46. NPLs system-wide increased to 29.8 percent in December 2015 from 19.1 percent in 2014. The NPL rate has doubled since 2011, but put in a historical context is still better than the low 
point in 2006 when 44 percent of loans were non-performing. However, the current NPL rate is above international standards for financial sector soundness and a significant source of concern, particularly given the weakness in collateral execution and court adjudication, discussed in detail below. Provisions as a percentage of NPLs increased to 90.4 percent in 2015 down from 105 percent in 2011. As banks are not profitable, many will likely see their capital erode from negative earnings and provisioning costs.

47. NPLs also vary significantly by sector (see figure below). As of October 2015, the sector with the largest share of NPLs is commerce with 44.5 percent of all NPLs. The increase in commerce NPLs is significant, but also concerning in light of 2010 commerce NPLs were just 3.9 percent of all NPLs. Between 2010 and 2015, consumption's share of NPLs rose from 21.1 to 35.2 percent. At the same time, industry's shares of NPLs have decreased, while construction and services have risen moderately. The increase in NPLs by sector is reflected in the aggregate format (see figure below).

Figure 10: Industry NPLs as a Percent of Total NPLs and Gross NPLs by Industry
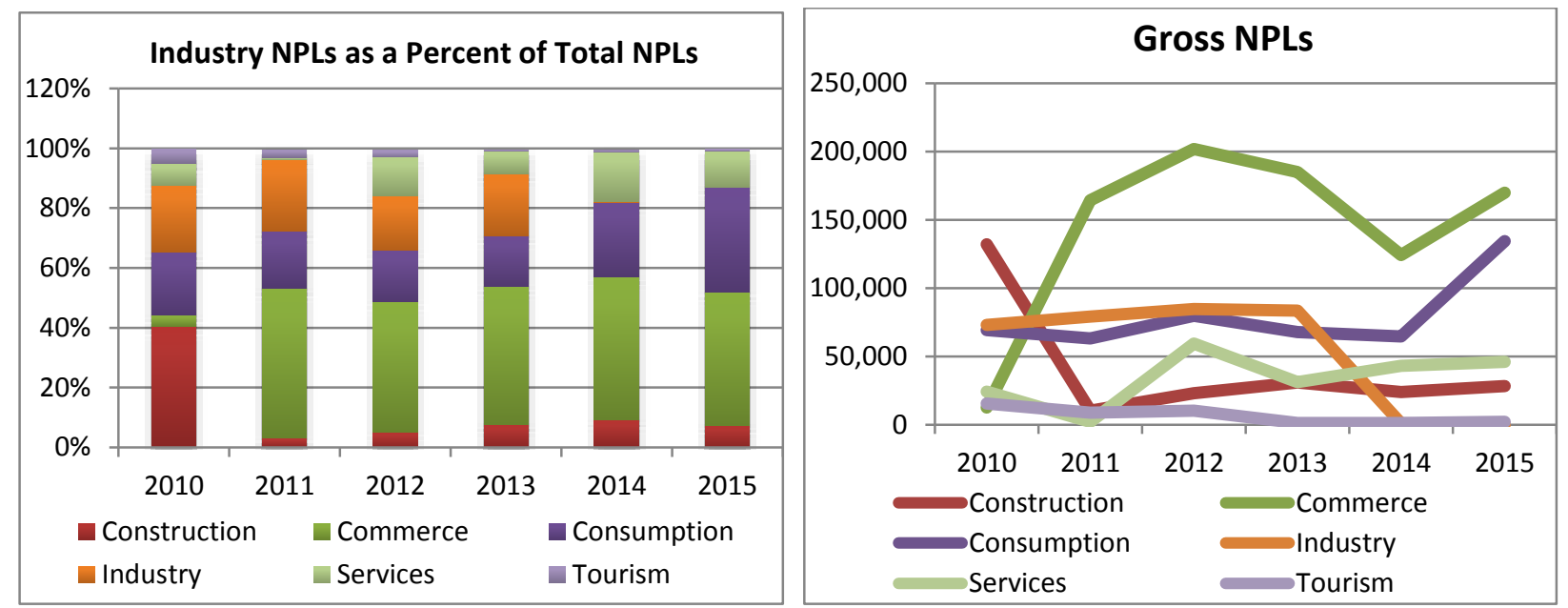

Source: BCSTP

48. The current arrangements for gathering data on the status of the banking system appears to be well established as the data gathered by the Banking Supervision Department (BSD) at the central bank is comprehensive and timely. However, it is less clear that the BSD is taking full advantage of the information contained in the reports in its discussions with commercial banks. For example, a key area in which data collection and analysis could be expanded to inform policy is through an asset quality review of banks. Such data usage may be particularly relevant in BCSTP's efforts to be more effective in its supervision of the banking sector. BCSTP faces constraints in its scope for implementing actions for the resolution of problem banks, so it is advisable that advisory actions be undertaken at an earlier stage and that BCSTP also takes advantage of all available information so as to be fully informed about the possible emergence of future issues.

49. In particular, it is noteworthy that the largest bank held provisions across all categories in excess of regulatory requirements. It is important that BSD understands the rationale for this 
approach (whether driven strictly by banking operations, or other considerations). It would be helpful if BSD could have detailed discussions with banks on the trajectory of their loan portfolio quality to identify factors that would affect the banking system overall. As the loan portfolio dynamic continues to be negative (and the overall volume of lending is decreasing), it would still be useful to have this understanding. It is also important to note that if loan portfolios do not increase, the NPL rate will naturally rise. 
Table 3: Loan Classification by Type

\begin{tabular}{|l|l|l|l|l|l|l|l|}
\hline & \multicolumn{3}{|l|}{} & \multicolumn{2}{l|}{$\begin{array}{l}\text { Banking System } \\
\text { (ex. Equador and Island) }\end{array}$} \\
\hline Loan Classification & Jun-14 & Mar-15 & Change & Jun-14 & Mar-15 & Change \\
\hline Normal (\%) & 76.0 & 67.2 & -8.8 & 72.7 & 62.6 & -10.1 \\
\hline Special mention (\%) & 10.8 & 10.9 & 0.1 & 12.7 & 15.9 & 3.2 \\
\hline Substandard (\%) & 2.3 & 8.7 & 6.3 & 2.9 & 5.8 & 2.8 \\
\hline Doubtful (\% & 3.4 & 2.0 & -1.5 & 3.5 & 3.0 & -0.5 \\
\hline Loss (\%) & 7.5 & 11.3 & 3.8 & 8.2 & 12.8 & 4.6 \\
\hline Total loans (dobras millions) & 855,622 & 753,389 & -11.9 & $1,476,009$ & $1,395,377$ & -5.5 \\
\hline
\end{tabular}

Source: BCSTP

50. According to a survey of banks, the average NPL rate for loans varies depending on its collateralization. Unsecured loans have a higher average NPL rate than loans secured by movable property and those secured with immovable assets such as real estate. ${ }^{16}$ Many of the foreign banks operating in São Tomé and Príncipe principally lend outside the country, which is likely due to the banks being primarily foreign-owned with connections abroad and possibly due to an increasing NPL rate within STP. At the same time, lending outside of the country is not a significant factor in constraining access to finance, as the banking sector is currently faced with excess liquidity from a reluctance to lend in an environment with an increasing NPL rate and economic growth slowing.

Table 4: Loans Secured by Movable and Immovable Collateral

\begin{tabular}{|l|l|}
\hline Type of Loan Security & \% of Loans \\
\hline Unsecured & 19.3 \\
\hline Secured by movable collateral & 4.3 \\
\hline Secured by immovable collateral & 46.5 \\
\hline Secured by movable and immovable collateral & 16.2 \\
\hline Unclassified & 13.7 \\
\hline
\end{tabular}

Source: World Bank, February 2015 Survey of Banks

\section{e. Banking Supervision}

51. The capacity of BCSTP to supervise the banking system has gradually improved, but remains limited. With technical assistance from development partners, such as the IMF, Bank of Portugal, and Central Bank of Brazil, BCSTP has developed its professional competency as a regulator; such as, the development of their internally developed credit registry. While capacity has improved, on-site inspections remain inconsistent and infrequent and corrective enforcement actions merit improvement. To address this shortcoming, BCSTP is undertaking efforts to improve its supervisory and regulatory oversight capacity of the financial sector by adding staff and

\footnotetext{
${ }^{16}$ NPL figures are from early 2015 and do not include all banks. As such, due to timing and cohort differences in the overall NPL information between these figures varies. What is instructive about the survey data is that better secured loans have lower NPL rates.
} 
increasing the rate of both off- and on-site inspections. Conducting a detailed assessment of banks compliance with Basel Core Principles would also enable BCSTP to enhance its supervisory capacity. At present, there is no prompt corrective action framework requiring supervisory action or automatic triggers associated with capital, liquidity, and asset impairment indicators.

52. The legal framework for the resolution of distressed institutions only contemplates liquidation and does not provide adequate legal protection for supervisors. The resolution method most commonly employed by the BCSTP has been the appointment of an individual or team to replace management and try to turn around a bank in an effort to restore the financial position and minimize losses for depositors and other creditors. This is typically a drawn-out process as evidenced by one bank, placed under curatorship in January 2015 and not resolved by December 2015. In addition, resolution processes are subject to legal challenges by owners (and other parties), which puts a stay in the process until these are resolved, often years later. As a result, the value of assets in banks under curatorship tend to deteriorate further and creditors, primarily depositors, face the risk of significant losses. Moreover, the current legal framework does not provide adequate legal protection for resolution authorities. BCSTP is undertaking a review of its laws related to crisis planning and legal instruments for the resolution of distressed financial institutions with technical assistance from the IMF and has presented a draft resolution law to Parliament. This review should also include assessing the prospects of new guidelines on resolution methods, such as the establishment of a workout approach and bank workout departments, revised write-off procedures and timeframe for writing off back logged NPLs.

53. Many of the FSDIP's recommendations aim to address the issue of high NPLs in São Tomé and Príncipe (see figure below). By strengthening financial sector supervision, increasing financial inclusion, and upgrading financial infrastructure, the FSDIP's multi-dimensional approach to financial sector development provides a comprehensive approach to address many of the factors that contribute to a high NPL rate. Ultimately, by strengthening financial stability, the FSDIP will contribute to more resilient economic growth, which is a key contributor to loan repayment rates. 
Table 5: FSDIP's Comprehensive Strategy to Address NPLs

\begin{tabular}{|c|c|c|}
\hline $\begin{array}{l}\text { Strategic } \\
\text { Area }\end{array}$ & \# & Summary of NPL Related Recommendations \\
\hline \multirow{6}{*}{$\begin{array}{l}\text { Strengthen } \\
\text { Financial } \\
\text { Sector } \\
\text { Supervision }\end{array}$} & 1 & Enhance supervisory capacity of off- and on-site supervision. \\
\hline & 2 & $\begin{array}{l}\text { Increase use of banking sector data to inform analysis and supervision of sector, including } \\
\text { conducting an asset quality review of banks. }\end{array}$ \\
\hline & 3 & Assess banks' compliance with Basel Core Principles. \\
\hline & 4 & Review and revise bank licensing procedures to ensure due diligence. \\
\hline & 5 & $\begin{array}{l}\text { Conduct a review of the regulatory framework to implement the new Bank Resolution Law, } \\
\text { including the resolution of distressed financial institutions. }\end{array}$ \\
\hline & 6 & $\begin{array}{l}\text { Strengthen regulatory framework for prompt corrective actions, improve contingency } \\
\text { planning and establish coordination mechanisms for crisis management. }\end{array}$ \\
\hline $\begin{array}{l}\text { Increase } \\
\text { Financial } \\
\text { Inclusion }\end{array}$ & 7 & $\begin{array}{l}\text { Implement market conduct and consumer protection standards for transparency of financial } \\
\text { products and interest rates. }\end{array}$ \\
\hline \multirow{7}{*}{$\begin{array}{l}\text { Upgrade } \\
\text { Financial } \\
\text { Infrastructure }\end{array}$} & 8 & Enhance existing credit registry. \\
\hline & 9 & Assess the impact of mandatory data contributions to the credit reporting system. \\
\hline & 10 & $\begin{array}{l}\text { Implement a comprehensive legal framework for credit reporting and a comprehensive } \\
\text { credit information system. }\end{array}$ \\
\hline & 11 & Revise the judicial review process for commercial and financial transactions. \\
\hline & 12 & $\begin{array}{l}\text { Train judges on commercial and financial adjudication techniques. Streamline adjudication } \\
\text { for small claims. Institute alternative dispute resolution mechanisms and arbitration. }\end{array}$ \\
\hline & 13 & $\begin{array}{l}\text { Develop strong auditing and accounting infrastructure and standards by establishing OTOCA } \\
\text { (professional accountancy organization), creating legislation stipulating auditing standards, } \\
\text { and updating chart of accounts. }\end{array}$ \\
\hline & 14 & Task OTOCA to train MSMEs on accounting and finance statement preparation. \\
\hline
\end{tabular}




\section{Legal and Regulatory Framework}

54. The Government has made significant progress reforming the financial sector's legal and regulatory framework. The Government has submitted to Parliament new laws on: (i) bank resolution (developed with IMF support); (ii) microfinance; and (iii) the central bank organic law. In addition, the BCSTP has enacted new microcredit regulation and is in the processes of drafting a new Financial Institutions Law with World Bank Group support. The UNDP is also supporting judicial reforms and may include training for judges on commercial and financial issues. ${ }^{17}$

55. Two laws regulate the financial sector: (i) the Financial Institutions Law (FIL) and; (ii) the Central Bank Law (CBL) both passed in 1992. FIL covers various entities including: a) special credit institutions, b) commercial banks, c) investment banks, d) financial companies, e) credit cooperatives, f) companies for real estate credit, and g) any other credit institution the Central Bank decides to regulate as providing financial services. Despite this long list of institutions, their respective activities are not fully articulated and the general provisions contained in the FIL only cover very basic issues such as the constitution and administration of a financial institution. Operational rules and obligations for BCSTP to oversee the banking and payment system are only covered to a limited extent in the existing FIL.

56. BCSTP is revising the Financial Institutions Law to reflect the economic, financial, and technological changes in the country. The original law, from 1992, was drafted with banks and insurance companies in mind and without consideration for other financial institutions like investment banks, brokerages, savings and loans, credit unions, and asset management companies. The new law, currently in a preliminary draft stage, is intended to provide a thorough review of instruments, tools and operating mechanisms for the full range of financial institutions found in other countries. The key characteristics of the draft FIL are: a) clear distinction between credit institutions, financial companies and insurance companies; b) expansion of economic and financial concepts; c) restructuring of permitted organizational structures; and d) provision for more types of companies, thereby increasing the range of options available for investors. With these changes, BCSTP will be responsible for licensing all financial institution and supervision of the financial system, as a whole.

57. As discussed above, very few and incomplete provisions are devoted to the right of the BCSTP to intervene in case of risk of insolvency by a financial institution. For example, according to the FIL, BCSTP must submit a request to the Court to declare the bankruptcy of a bank and suggest the receiver to be appointed. At present, there is no specific law that regulates the liquidation of a bank. The CBL lists the competences of BCSTP as monetary policy, foreign exchange, and supervision of the financial sector. However, these are not further articulated. Moreover, the CBL

\footnotetext{
${ }^{17}$ Additional analysis of the legal and regulatory environment is included in Annex IX.
} 
does not recognize the independence of the BCSTP from the Government and contains no provisions to safeguard its autonomy.

\section{a. Legal Reforms in Process and Needed}

58. The current Central Bank Law does not recognize the independence of BCSTP from the Government and contains limited provisions to safeguard its autonomy.

59. Government intends to upgrade the existing regulatory framework in order to strengthen the surveillance of the sector and ability to resolve distressed institutions. BCSTP, with technical assistance from the IMF, submitted a new draft CBL to Parliament, which would strengthen the autonomy of the central bank in line with international standards. The new law would also provide the BCSTP with the authority and instruments necessary to monitor financial markets and act as needed, as well as better articulate its competencies and tools, including in case of the default of financial institutions. There are currently ten draft laws or regulations related to the financial sector that have been prepared and are at different stages of approval.

Table 6: Laws and Regulations under Review

\begin{tabular}{|l|l|l|}
\hline No. & Law/Regulation & Current Status \\
\hline 1 & Microcredit Regulation & Enacted in June 2015 \\
\hline 2 & Decree on intermediation (agency) in insurance & Approved by BCSTP \\
\hline 3 & Bank Resolution Law & Approved by Parliament and signed into law \\
\hline 4 & Central Bank Law & Under revision \\
\hline 5 & Financial Institutions law (FIL) & Under development \\
\hline 6 & Microfinance Law & Under development \\
\hline 7 & Compulsory Automobile Insurance Law & Submitted to Parliament for approval \\
\hline 8 & Pension Funds Regulation & At technical review stage \\
\hline 9 & Insurance Contracts Regulation & At technical review stage \\
\hline 10 & Deposit Insurance Law & Initial scoping and feasibility analysis \\
\hline
\end{tabular}

Source: BCSTP

60. Enhancing the legal and regulatory framework in the financial sector is necessary to better define the scope of activities for different financial institutions and to regulate those that are currently unregulated (i.e., microfinance/financial cooperatives and pensions). BCSTP has already elaborated a preliminary draft of the FIL and is working on a number of other draft laws and regulations. The Central Bank will also soon start a full revision of existing Normas de Aplicação Permanente (NAPs). In particular, in addition to a new draft of the FIL (see below), BCSTP is working on a separate law on microfinance, as well as on draft regulations on microcredit, pension funds, pension funds for BCSTP staff, and the establishment of a Commission for Pension Funds for BCSTP staff.

61. The draft FIL is more in line with international best practice and covers main areas of concern; however, there are still a number of inconsistencies in the draft legislation. The draft of the FIL 
contains more detail provisions for the regulation of individual institutions than the law currently in force. It separates financial institutions into three categories, i.e., institutions that provide credit, other non-credit financial institutions, and insurance companies, and lists permitted activities by type of institution. It then regulates the procedures for authorization, ownership and conflict of interests, administration and behavioral duties, prudential and supervision requirements, and procedures for reorganization. Insolvency procedures are contained in the draft Bank Resolution Law.

62. The draft Microfinance Law is still at a very early stage and its adoption could help promote financial inclusion. It covers micro-credit, micro-savings, micro-insurance and other forms of financial intermediation. The draft FIL includes microcredit companies within the category of credit institutions but does not discuss other micro financial activities. The draft Microfinance Law potentially conflicts with the draft FIL at least as for some requirements for microcredit institutions. BCSTP is working to clarify whether entities subject to the Microfinance Law - which are obliged to be cooperatives, saving and credit banks or financial companies for microcredit should also comply with the general rules in the FIL on those specific institutions.

63. A separate law will govern insurance intermediation. Although the draft FIL includes insurance among financial services, it intentionally does not regulate insurance intermediaries, as they will be the subject to a separate legal framework. Work on this new legal instrument for insurance service providers has not yet commenced. In drafting this law, it is necessary to clarify the institutional organization of supervisory and oversight powers over the insurance sector, currently supervised by BCSTP.

64. An effective legislative and regulatory framework would also need to cover electronic transactions and electronic transfers including mobile money and payments. Modernization of the financial market requires the digitalization of many services. This also affects financial inclusion, since digital financial instruments could serve a large component of the unbanked or under banked population. This would require an adequate legal basis that would recognize full enforceability to electronic data collection and storage, transactions, authorization, and transfers. These provisions would also benefit investments in the country and the efficient establishment of centralized registries for credit and other financial purposes. BCSTP still needs to formulate rules on electronic transactions and transfers, which can be the basis for additional technical assistance based on existing models and international best practice.

\section{b. Collateral Framework}

65. The legal framework for the execution of collateral in São Tome and Príncipe dates back to the Napoleonic era and does not adequately address the needs of borrowers for credit, particularly those secured by movable collateral. There is also no specific legal framework regulating lending devices or asset based finance involving movable collateral. Financial institutions in STP rely on general laws - mainly the Civil Code and Commercial Code - for 
performing their daily-secured credit transactions. The most popular secured lending instruments are mortgages and simple pledges, mainly on vehicles. Leasing and factoring services are non-existent.

66. São Tome and Príncipe does not have a specific law on Secured Transactions. The purpose of having a modern and functional secured transactions system is to provide access to credit for all economic sectors, and all types of economic actors. Secured transactions systems (the use of movable property as collateral for a loan) enable businesses and consumers to use their assets as security to generate capital. Secured transaction loans are typically secured by a company's accounts receivable, inventory, and equipment, and they primarily benefit start-ups and small and medium enterprises (SMEs) that do not have real estate or land to mortgage - from the farmer pledging his crop as collateral for an agricultural loan, to the manufacturer of consumer or industrial goods pledging his raw materials and finished products for working capital, to the seller of goods or services pledging the cash flow from its customer accounts as collateral for business expansion. In short, an effective secured transactions framework expands the base of assets, which can be used as collateral for a loan and thus access to capital.

67. São Tome and Príncipe's secured transactions system is characterized by a fragmented legal framework with scattered provisions on financing secured lending with movable property in different parts of the legislation, included mostly in the Civil and Commercial Codes. Furthermore, there is no centralized electronic registry for security interests in movable or immovable property. The system is based on the civil law tradition and reforms in this area have never been introduced. Thus, there is need to pass a modern legal framework for secured transactions and train businesses and lenders on this and on suitable collateral guarantees.

68. The Civil Code regulates the pledge ("penhor") and the mortgage ("hipoteca"). According to the Civil Code, a pledge grants the creditor the right to obtain payment from the value of a movable asset or from any asset that cannot be subjected to mortgage belonging to the debtor or a third party with preference over other creditors. The pledge is only effective when the debtor transfers possession of the encumbered asset or of the property title to the creditor. ${ }^{18}$

69. As in many countries with a civil law tradition, in São Tome and Príncipe many contracts require the intervention of notaries public to be valid. Some commercial transactions require the form of a public deed performed by the notary public. Other acts require authenticity by the notary, which means that the notary has revised and recognizes the document prepared by the parties; and other acts require the sole recognition of the parties' signatures by the notary.

70. All institutions interviewed during the diagnostic reported that existing land and property registries are inefficient, expensive, and unreliable with a fee schedule that is difficult to understand. The General Direction for Registries and Notaries (Cartorio), which is administered by the Ministry of Justice, oversees the land registry (Registo Predial), property registry (Registo

\footnotetext{
${ }^{18}$ See Article 699 and subsequent Articles of the Civil Code.
} 
de Propiedade) and the vehicles registry (Registo Automóvel) among others. Mortgages (hipotecas) are registered at the property registry and pledges (penhor) at the vehicles registry.

71. Existing land, property, vehicle and mortgage registries of São Tome and Príncipe are currently paper-based and are manually performed (although there is an upcoming project to digitalize it). Registrations of titles, mortgages, pledges and searches are also manual and the officers must consult the existing paper books. Therefore, registering and consulting takes a long time and overall, current processes are cumbersome and not efficient.

72. A key part of a modern secured transactions law is an efficient centralized electronic (web based) registration system based on notices and not on document registration. Unlike title (ownership) registries such as a real estate registry, a secured transactions registration registry does not create or transfer property rights. Such movable collateral registration serves two functions: (1) it notifies third parties of the existence of the security interest and (2) it establishes the priority status of a security interest based on the date of registration. Establishing a moveable collateral registry is critical to leveraging the potential of the secured transactions law by increasing access to information on assets and thus potentially a creditor's willingness to provide loans based on these assets.

\section{c. Court Adjudication}

73. Courts play a key role in the enforcement of contracts by enabling banks to recover assets (both movable and immovable in nature) vis-à-vis judicial rulings in the event of a debtor's default. Without the ability to properly enforce these contracts through the judiciary, financial institutions are less incentivized to lend and, thus, collateral is not leveraged as extensively as possible to promote lending to the private sector. Yet as highlighted above, there is no comprehensive framework for secured transactions to more effectively guide judges in their rulings on contract enforcement commercial and financial matters.

74. The judiciary's lack of specialization and training in commercial law and financial matters preclude the effective enforcement of contracts. As a result, the judicial system is highly unreliable in resolving commercial matters, which makes it difficult for financial institutions to collect from delinquent borrowers. Financial institutions state that the enforcement procedures for loan contracts are a significant problem that impedes their ability to rely on collateral to secure credit or willingness to engage in unsecured lending. Further complicating the process is the lack of transparency in the judicial process. The result is excessive cost and delays that prevent recovery of possession while the collateral still has its full value. Realization of the collateral after possession is recovered is problematic as the secondary market for selling collateral is practically non-existent for most assets. ${ }^{19}$

\footnotetext{
19 Interview with different stakeholders, including some of the banks and the bar association.
} 
75. Significant delays and uncertainty in collecting on past due loans serves as a deterrent for banks to lend. Repossession of collateral is in fact very difficult and expensive. Enforcement procedures generally take two to three years for salary-based lending and up 10 years for loans secured by home. Some institutions reported out of court settlement in exceptional cases. Some institutions have developed mechanisms (i.e., including out of court enforcement clauses for movable collateral in their credit agreements), which allow them to seize collateral without judicial intervention - while efficient this is potentially not in consumer's interest. These processes are not commonly used since the creditor and the debtor must agree on all terms of execution or otherwise must follow the lengthy judicial procedure.

76. As result of the critical role collateral plays in promoting access to finance and yet the challenges to collateral execution, there is a need to not only pass a modern legal framework for secured transactions, but to also revise the judicial review process for commercial and financial transactions and train judges on commercial and financial adjudication techniques.

77. At the same time, however, not all contract enforcement cases and disputes require or merit the same degree of adjudication as cases involving larger amount of money or which are more complex in nature. Consequently, there is also a need to streamline adjudication for small claims and institute alternative dispute resolution mechanisms and arbitration.

\section{d. Comprehensive Review of Regulatory Framework}

78. In light of the array of issues facing the financial sector and the various reforms under development, it becomes necessary to conduct a comprehensive review of the regulatory framework, including crisis planning and legal instruments for the resolution of distressed financial institutions. It is also imperative to establish a coherent, comprehensive and harmonized legal and regulatory framework for the financial sector by identifying gaps and inconsistencies in current and draft legislation, and amending and creating new legislation where pertinent. All relevant laws, rules and regulations should also be available on government websites. 


\section{Financial Inclusion}

\section{a. MSME Access to Finance}

79. Reliable data on the number of MSMEs and constraints in terms of accessing finance in São Tomé and Príncipe does not exist. In the absence of an Enterprise Survey, and with the aim of providing estimations and an approximate picture of the financing gap for MSMEs in developing economies, the IFC has developed the Enterprise Finance Gap Database. ${ }^{20}$ Based on available enterprise surveys in the region, IFC estimates that only 7 percent of MSMEs have a bank loan. Competitiveness and growth is supported when local businesses (particularly MSMEs) have access to credit to finance their activities. Despite the dominance of MSMEs in the private sector (in terms of numbers), their access to finance is limited.

80. The Framework of Businesses Law provides a classification of firms' size by number of employees and maximum annual income (see: Table below). Stakeholders nevertheless seem unaware of this definition and banks do not have data disaggregated by firm size.

Table 7: Classification of Firms by Size

\begin{tabular}{|l|l|l|}
\hline Firm size & $\begin{array}{l}\text { Number of } \\
\text { employees }\end{array}$ & $\begin{array}{l}\text { Maximum annual income } \\
\text { (millions of dobras) }\end{array}$ \\
\hline Micro & $1-3$ & 90 \\
\hline Small & $3-12$ & $90-900$ \\
\hline Medium & $12-30$ & $900-2,250$ \\
\hline Large & $>30$ & $>2,250$ \\
\hline
\end{tabular}

81. MSME access to finance is also constrained based on weak auditing standards and accounting records, which make credit analysis difficult. In June 2014, the World Bank conducted a study on the Observance of Standards and Codes - Accounting and Auditing (ROSC A\&A). The report indicates that the country is at an infant stage of development of the institutional pillars that support the accountancy profession. This has been primarily attributed to minimal understanding of the role and contribution of the accountancy profession to the economy, lack of any legislation stipulating auditing standards to be used, out dated chart of accounts and no official organization to establish and adopt accounting and auditing standards. The Minister for Planning and Finance has worked to establish a professional accountancy organization called Ordem dos Tecnicos Oficias de Contas e Auditores (OTOCA). OTOCA drafted and submitted to the Minister of Planning and Finance an accountancy law on establishing OTOCA in April 2014. The Minister has committed to presenting the law in National Assembly for enactment.

\footnotetext{
${ }^{20}$ See: http://financegap.smefinanceforum.org/
} 
82. In August 2015 the IFC and BISTP announced a US\$3 million risk-sharing facility to provide working capital and loans to small businesses, support their expansion and modernization, and drive job growth in which they will share an equal amount of the lending risk. Effectively designed, partial credit guarantee schemes that follow best practices, such as the ones in Chile are associated with a 14 percent higher probability for small firms to get a loan. Such mechanisms may be able to help fill the finance gap that MSMEs are currently experiencing while not distorting the functioning of credit markets.

\section{b. Savings}

83. Supply-side data from BCSTP's National Financial System Report 2014 indicates that 48 percent of the population has a savings account at a bank. ${ }^{21}$ Despite low levels of income in São Tomé and Príncipe and dispersion of the population these admirable levels of account ownership are the result of relatively low financial, documentation and physical barriers to enter the financial system. While account ownership figures in STP compare favorably with other countries in Sub-Saharan Africa where just 23 percent of adults have a savings account, there is significant room for improvement. ${ }^{22}$ A major constraint in assessing the potential for making the financial system more inclusive is that no demand-side surveys exist on the usage of financial services. Thorough demand-side surveys have recently been conducted in other markets in sub-Sahara Africa and proven to be effective at helping policymakers and financial institutions identify the opportunities for improvement. ${ }^{23}$

84. There are 27 bank branches in 5 of the 7 districts of the country where 86 percent of the population lives (see figure below). The documentation requirements to open a savings account include a national ID, which is widely accessible, the minimum opening deposit is between USD \$10-25 and there are semi-annual or annual fees.

85. The average amount of savings by individuals is US\$57 or 3.5 percent of per capita GDP indicating a moderate degree of financial vulnerability among households. With a gross savings (i.e., gross national income less total consumption, plus net transfer) to GDP ratio of just 18 percent in 2013, Sao Tome and Principe lags behind other lower-middle income countries that average 29 percent and even lower income countries at 25 percent.

\section{Figure 11: Geographic Distribution Bank Branches: Two Circled Districts Lack Access}

\footnotetext{
${ }^{21}$ This is calculated based on data provided by commercial banks. These estimates are the best available data given that no demand side surveys have been completed. The World Development Indicators show that in 2013 there were 720 depositors in commercial banks for every 1,000 adults or $72 \%$ of adults. This is before taking into account the estimated number of consumers that have more than one bank account.

22 Demirguc-Kunt, Asli Leora Klapper, Financial Inclusion in Africa: An Overview. World Bank, June 2012.

${ }^{23}$ Although a demand side survey is an important tool to promote financial inclusion, the limited and focused scope of the STP FSDIP necessitates such a survey taking place at a later point in time.
} 


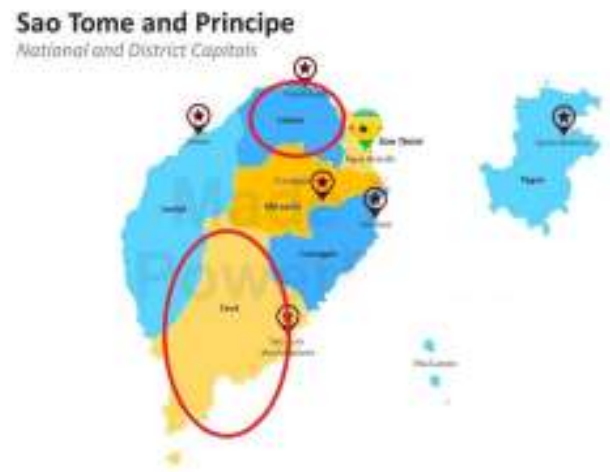

86. Access to bank accounts can also be promoted through government-to-person (G2P) other bulk and recurrent payments, such as all government salaries, via deposits in bank accounts, which necessitates account ownership. Additionally, providing customers the option to choose their bank for these payments will increase competition in the banking sector.

\section{c. Credit}

87. Supply-side data indicates that less than 5 percent of adults are clients of consumer finance firms. There are three privately owned consumer finance organizations that are primarily payday lenders in STP. The largest of these institutions has 3,300 clients, three offices and 12 million dollars in assets. While these organizations are considered microfinance institutions in the local context they appear to be primarily payday lenders (i.e., 60 percent of their loans) to salaried persons that have been turned down by banks. These loans are generally 1 day to 7 months in duration with interest rates of 55 percent and higher. While the largest consumer lender discloses the loan payment that is due, the interest rates on the loans are not included in the loan agreement. The largest of these organizations is lending its own funds, does not collect any type of mandatory or voluntary savings and has non-performing loans of 35 percent of total loans. Based on interviews with the organization it is profitable and it does a limited amount of collateral based lending.

88. None of these consumer/microfinance organizations are subject to prudential regulation or market conduct supervision and they do not contribute data to or receive data from the central bank's central credit registry. ${ }^{24}$ Although over 100 countries have financial cooperatives and/or other socially oriented microfinance institutions which aid in serving lower-income groups neither type of institution is not currently found in São Tomé. In many markets, financial cooperatives are able to effectively serve a lower and moderate income segment of the population that commercial banks find unprofitable or only marginally profitable. It is imperative

\footnotetext{
24 There are not any microfinance institutions that appear focused on serving microenterprises and/or that have a double bottom line of measuring their social and financial impact. As such, the term consumer finance institution is referenced as opposed to microfinance institution.
} 
that microfinance institutions and consumer lenders come under central bank market conduct and prudential supervision.

89. In a context, where 7 percent of MSMEs have a bank loan, less than 5 percent of adults are clients of consumer finance firms, yet 48 percent of population has a savings account, it is clear that there space to enhance financial inclusion beyond savings account ownership. The lack of access to credit reduces individuals and MSMEs capacity to stimulate their incomes and smooth consumption, which ultimately contributes towards the poverty rate of 62 percent.

\section{d. Mobile Financial Services}

90. The main telecommunications firm, CST, indicates that there are 146,000 mobile lines in STP and 86 percent of the total population has a mobile phone. CST has 250 primary agents (and 300 subagents) in all districts of the country. There are two telecommunication companies in STP. The largest, CST, has a 90 percent market share and is 49 percent government-owned and 51 percent by a Portuguese telecom company. With mobile phone penetration significantly above the level of adults that have bank accounts, an opportunity exists to expand the frontiers of financial services via digital financial services.

91. Currently CST subscribers can transfer airtime among each other as a form of airtime payment/compensation. However, CST agents do not offer "cash-out" services where a client can convert airtime into cash and take it out of the system thus severely limiting the usefulness of the service as a savings or payment instrument. In addition, consumers and businesses are not accepting CST airtime as a form payment. CST does not appear to have any plans to introduce an e-money product and there is no explicit legislative or regulatory framework for it. It is imperative to permit agent banking among financial institutions by allowing banks to partner with local firms as banking agents.

\section{e. Insurance}

92. Supply side data indicates that 4.3 percent of the adult population, or 4,800 persons above 15 years of age have some form of private insurance. Although this is a small number of policyholders, overall it is only slightly below the average in other lower or lower-middle income countries in Africa (i.e., Mozambique and Zambia) where 5 percent of the population uses insurance products. Premium income for auto insurance accounts for 50 percent of all insurance premiums according to BCSTP's 2014 data. It is widely believed by insurers that the mandatory auto insurance requirement is not followed and that a review of the current auto insurance requirement needs to be undertaken. There are only two locally registered but foreign-owned insurance companies in STP. Similar to the higher-end credit needs of the market, the higher-end corporate insurance needs seem to be met primarily through foreign insurance providers. This could also be a result of the relatively small and limited lines of business offered by the two 
insurance companies. The limited role of insurance highlights the space for growth and diversification of products.

\section{f. Consumer Protection and Financial Education}

93. In 2011, BCSTP issued a regulation on consumer protection that applies to banks, insurance providers and exchange houses - it does not apply to consumer finance or microfinance organizations. The 2011 regulation establishes a complaint and re-course mechanism that is presently utilized. ${ }^{25}$ Under this framework the BCSTP receives complaints and can sanction banks, insurance providers and exchange houses. The consumer protection framework, however, is incomplete as neither the 2011 consumer protection regulation nor other regulation/legislation establishes a standardized method of disclosure, there is no general data privacy law, there is not a framework in place to monitor over-indebtedness and there is little interaction between market conduct and prudential supervision. With increasing NPLs, having a framework to assess and monitor complaints and other critical issues, such as over-indebtedness, is increasingly critical.

94. An educated consumer is also much more likely to be a well-protected consumer. However, it is difficult for the consumer to be educated and/or protected on these issues when there are no standards for the transparency of financial products and interest rates. Neither BCSTP nor private banks have any organized programs on financial education for consumers. As the availability of financial services and credit has grown in São Tomé and Príncipe, there is ample evidence based on the high-level of non-performing loans that many consumers did not understand or misjudged their capacity to repay loans. As a result, there is a need to conduct a base-line financial literacy study for consumers on a gender-disaggregated basis in order to help better understand their different challenges and a financial literacy campaign based on the study. ${ }^{26}$ Furthermore lenders should be obliged to consider a borrower's capacity to repay and existing debts in loan decisions. Providing suitable education to consumers at teachable moments can be beneficial to both providers of financial services and consumers. Understanding how to mitigate financial vulnerabilities through various forms of insurance can also help consumers.

\section{g. Doing Business}

95. In Doing Business 2016 report, out of 189 countries, São Tomé and Príncipe ranks 185 on the Getting Credit indicator and 166 on the Ease of Doing Business. ${ }^{27}$ The Getting Credit indicator has two components: the Legal Rights Index measures the protection of creditor and debtor rights in

\footnotetext{
25 There were 12 complaints filed in 2014 with the Central Bank.

${ }^{26}$ Although a baseline financial literacy study and campaign are key concerns, the scope of this project dictates their undertaking at a later period in time.

27 The Doing Business rankings are a World Bank initiative, which provides an objective measure of business regulations for local small and medium firms in 189 economies and selected cities at the subnational level.
} 
collateral and bankruptcy laws, while the Credit Information Index captures the depth and breadth of credit information. On the Legal Rights Index, São Tomé and Príncipe scores zero out of a possible 12 points, indicating that creditors do not enjoy the same degree of predictability, certainty and protection that creditors in other economies do to secure loans using a variety of moveable assets. São Tome and Príncipe lags behind other sub-Saharan African countries in the ease of small and medium business access credit ranking.

96. São Tome and Príncipe could potentially improve its overall position in the Doing Business ranking and its Getting Credit indicator, if it reforms its framework for secured transactions. Making such reforms could greatly improve the availability and access to credit for enterprises and individuals. A legal reform only would improve the ranking, but would have no impact on the ground in terms of improving access to credit, since those results would only materialize when there is a functioning movable collateral registry and the secured transactions law has been implemented. 
Table 8: Strength of Legal Rights Index in São Tomé and Príncipe

\begin{tabular}{|c|c|c|}
\hline No. & Indicator & STP \\
\hline 1 & $\begin{array}{l}\text { Does an integrated or unified legal framework for secured transactions that extends to the } \\
\text { creation, publicity and enforcement of functional equivalents to security interests in movable } \\
\text { assets exist in the economy? }\end{array}$ & No \\
\hline 2 & $\begin{array}{l}\text { Does the law allow businesses to grant non-possessory security rights in single category of } \\
\text { movable assets, without requiring specific description of the collateral? }\end{array}$ & No \\
\hline 3 & $\begin{array}{l}\text { Does the law allow businesses to grant non-possessory security rights in substantially all } \\
\text { assets, without requiring specific description of the collateral? }\end{array}$ & No \\
\hline 4 & $\begin{array}{l}\text { May a security right extend to future or after-acquired assets, and may it extend } \\
\text { automatically to the products, proceeds or replacement of the original assets? }\end{array}$ & No \\
\hline 5 & $\begin{array}{l}\text { Is general description of debts permitted in collateral agreements, can all types of debts be } \\
\text { secured by parties, and can the collateral agreement include a maximum amount for which } \\
\text { the assets are encumbered? }\end{array}$ & No \\
\hline 6 & $\begin{array}{l}\text { Is a collateral registry in operation for both incorporated and non-incorporated entities, that } \\
\text { is unified geographically and by asset type, with an electronic database indexed by debtor's } \\
\text { names? }\end{array}$ & No \\
\hline 7 & $\begin{array}{l}\text { Does a notice-based collateral registry exist in which all functional equivalents can be } \\
\text { registered? }\end{array}$ & No \\
\hline 8 & $\begin{array}{l}\text { Does a modern collateral registry exist in which registration, amendments, cancellations and } \\
\text { searches can be performed online by any interested third party? }\end{array}$ & No \\
\hline 9 & $\begin{array}{l}\text { Are secured creditors paid first (i.e. before tax and employee claims), when a debtor defaults } \\
\text { outside an insolvency procedure? }\end{array}$ & No \\
\hline 10 & $\begin{array}{l}\text { Are secured creditors paid first (i.e. before tax and employee claims), when a business is } \\
\text { liquidated? }\end{array}$ & No \\
\hline 11 & $\begin{array}{l}\text { Are secured creditors either not subject to an automatic stay on enforcement when a debtor } \\
\text { enters a court-supervised reorganization procedure? Does the law protect secured creditors' } \\
\text { rights by providing clear grounds for relief from the stay and/or sets a time limit for it? }\end{array}$ & No \\
\hline \multirow[t]{2}{*}{12} & $\begin{array}{l}\text { Does the law allow parties to agree on out of court enforcement at the time a security interest } \\
\text { is created? Does the law allow the secured creditor to sell the collateral through public } \\
\text { auction and private tender, as well as, for the secured creditor to keep the asset in } \\
\text { satisfaction of the debt? }\end{array}$ & No \\
\hline & Total number of yes responses & 0 \\
\hline
\end{tabular}

Source: Doing Business 2015 


\section{Financial Infrastructure}

97. A country's financial infrastructure enables financial institutions, consumers and business to conduct transactions securely and efficiently. Components of the financial infrastructure within Sao Tome and Principe include the credit registry (central de riscos), the collateral registry system and the payments and settlement systems.

\section{a. Credit Registry}

98. BCSTP maintains a credit registry of all current loans by banks. While this initial effort by BCSTP to improve the credit information system is helping, more work is needed to improve the utility of the credit registry. Banks share their list of outstanding loans of over 4 million dobras every 30 days to the registry. BCSTP could improve this system by requiring historical data on borrowers - not just active loans - providing a consolidated view of a borrower's loans, arrears, and overdraft amounts in the credit report. In addition, the credit analysis could also be improved by adding multi-borrowing, overall borrower credit quality indicators and ensuring that all lenders, not just banks, are contributing data and can utilize it. Utilities and telecom providers are an important source of data. It would also be important to first research the potential impact of making data contributions mandatory to the credit reporting system.

99. Few lenders are referencing the credit registry for lending decisions today given gaps in its information. The existing credit information system does not provide consolidated credit concentration information by institution and borrowers, which is necessary for lenders to assess loan repayment capabilities of potential borrowers. Only some banks and none of the microfinance institutions and consumer lenders provide information to the credit registry. Those that do only provide information on a monthly basis instead of in real time. The credit registry does not utilize an algorithm to produce a credit score that could standardize credit risk analysis.

100. There are single points of failure without sufficient back-up equipment and no disaster recovery plan for the central bank and its IT communications infrastructure with banks. Although stable and well managed, the communications infrastructure has several hardware, software, and capacity limitations that present undue risk to the banking system. Improving server and back-up capacities, having duplicate routers, a disaster recovery site and plan (that is tested), and improved physical and data security are strongly recommended for the central bank and the platforms it operates including the central credit registry.

101. Credit reporting and collateral registries are crucial components of the financial infrastructure as they promote access to finance and financial stability. Comprehensive and well- 
functioning credit reporting systems reduce information asymmetries, support efficient credit allocation and strengthen risk management. If the BCSTP decides to implement the necessary upgrades of the credit registry (both in terms of security and upgrades of the process, functions, reports and resources) there will be a big potential for building economies of scale and potentially host the Collateral Registry within the same technology platform. In other jurisdictions, both systems share the same premises, hardware and resources, even when the software systems as well as the databases should be treated separately. (See annex on Credit Registry Gap Analysis).

\section{b. Secured Lending}

102. Most financial institutions in São Tome and Príncipe consider both movable and immovable property risky when securing credit, but in general they prefer immovable property as collateral. ${ }^{28}$ The value of immovable property is more stable and easier to establish than movable assets. In addition, financial institutions see various problems inherent with movable property, including its quick depreciation, difficult re-possession and final sale of the collateral in such a small market.

103. The average interest rate for loans secured by movable assets is high at 18.5 percent based on the surveys. However, for immovable assets it is 15.5 percent showing that most banks consider the use of movable property as collateral riskier than using immovable collateral. For the unsecured loans, the average interest rate is around 26 percent.

104. Future assets and proceeds are not considered part of the security interest. The current legal framework does not regulate the possible use of any future assets as security interests. Conceptually and practically, it is not possible to take a possessory pledge over an asset that the debtor has not yet acquired. In countries with a modern collateral registry, however, movable assets with frequent turnover like inventory, farm products and accounts receivable are sold and collected regularly, changing their nature into cash. If the law does not extend the lender's security interest to future assets and proceeds, lenders are forced to execute new security agreements or modify existing ones, the cost of which is eventually borne by the borrowers.

28 Interviews with commercial banks. 


\section{Box 1: Collateral Registries and Moveable Assets as Security}

Reforming movable collateral frameworks contributes to increasing levels of credit at decreasing costs. In countries where security interests are perfected and there is a predictable priority system for creditors in case of default, credit to gross domestic product (GDP) averages 60 percent compared with 30-32 percent averages for countries without a clear creditor protection system.

Experience from industrialized countries shows that borrowers using collateral get nine times the level of credit, repayment periods up to 11 times longer, and interest rates 50 percent lower than borrowers without collateral. World Bank research shows that the introduction of movable asset registries has a positive effect on firm financing, with: (i) an increase in access to finance by 8 percentage points; (ii) an increase in access to a loan by 7 percentage points; (iii) an increase in percentage of working capital financed by banks by 10 percentage points; and (iv) an increase in loan terms by 6 months and a reduction in interest rates by 3 percentage points.

105. A World Bank diagnostic survey of commercial banks, which sought to obtain baseline data, secured lending by banks found that banks in São Tomé and Príncipe rarely take movable property as collateral. ${ }^{29}$ The most common forms of security in movable assets are: (i) purchase money for vehicles; (ii) interests in account receivables; and (iii) pledges on machinery and equipment. Based on the volumes, however, these types of security are not common. In addition, for vehicles there is a prerequisite of transferring the title and the car's insurance to the name of the bank before obtaining a loan.

106. The strong preference of lenders for security in real estate restricts access to finance for MSMEs, which in most cases, do not have real estate to pledge as collateral. As a result, lenders will either not lend or lend only on unfavorable terms and in amounts that are inadequate. ${ }^{30}$ The potential credit gap for MSME lending is further explored in the section on Financial Inclusion.

\section{c. Payments and Remittances}

107. The payments infrastructure is lacking making international transactions. There are 27 bank branches, 26 ATMs and 59 Point-of-Sale devices in the country. The lack of an international connection to Visa or MasterCard means that local banks cannot offer credit cards and foreign visitors with such cards cannot use them widely on the islands. The local payments company, São Tomé Príncipe Automated Payments (SPOUT), is jointly owned by BCSTP and banks, operates the country's Dobra24 ATM network and has the exclusive rights to operate all POS devices. To service tourists and foreign visitors many international hotels have developed a relationship with an overseas bank to accept international credit cards. This keeps domestic banks out of a potentially important fee-income source (i.e., interchange fees), limits their ability to offer revolving credit via credit cards and limits the tourism infrastructure.

108. BCSTP maintains the country's only connection to the international SWIFT network but banks do maintain international correspondent relationships. Check payments are presented

\footnotetext{
${ }^{29}$ Five of the seven banks, which represent $85 \%$ of the assets of the banking system, responded to the survey.

30 Interview with commercial banks.
} 
manually to a single clearing company (Sequioy) and settlement occurs the same day. All civil servants are required to have a bank account and the Treasurer's office, within the Ministry of Finance, manually provides local banks with lists of salaries to be credited. While still including manual processes, the requirement to have an account for receiving government payments reduces government expenses, leakages from cash payments and promote the usage of formal financial services.

109. Sao Tome and Principe received USD 26.8 million in international remittances in 2014 equivalent to 8.1 percent of GDP. The source of remittances include, in order of importance: France, Portugal, Luxemburg, Angola, Belgium and the United States. Western Union is a key market participant yet it has just six points of service in the country.

Figure 12: Remittance Dependency, Select Countries, 2014

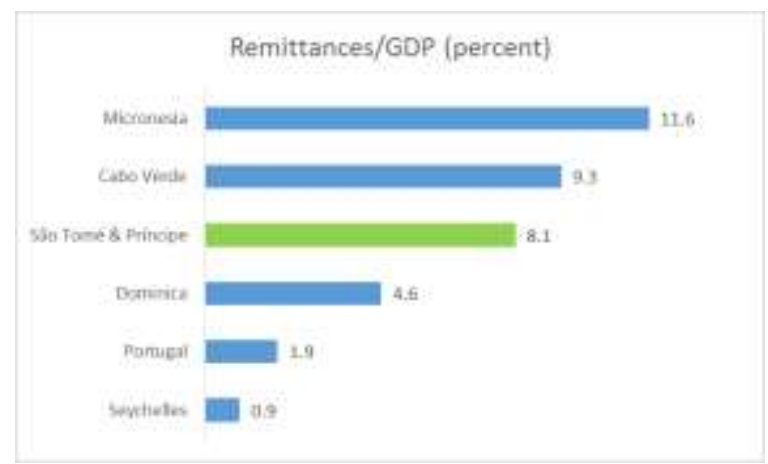

Source: World Bank 


\section{Implementation, Monitoring and Evaluation of the FSDIP}

110. A Financial Sector Development Committee (FSDC) will be responsible for executing the FSDIP. The governance structure of the committee will be comprised of the Minister of Finance as Chair, the Governor of the BCSTP as vice chair, and the Ministers of Economy and Justice, or their representatives, as members. A technical team comprised of Directors and Staff from the Ministry of Finance, BCSTP, Ministry of Economy, Ministry of Justice, and other line ministries as needed, will be responsible for day-to-day implementation of the FSDIP. The technical team will oversee thematic working groups established to focus on particular sub-sectors. The working groups will be comprised of public and private sector representatives that will be working to support and execute the recommendations in Annex I. Potential examples of their activities could include drafting or commenting on rules, regulations or bills, holding trainings or conducting research. A secretariat will support the work of the technical team working groups and report to the FSDC.

Figure 13: Governance Framework for the FSDIP

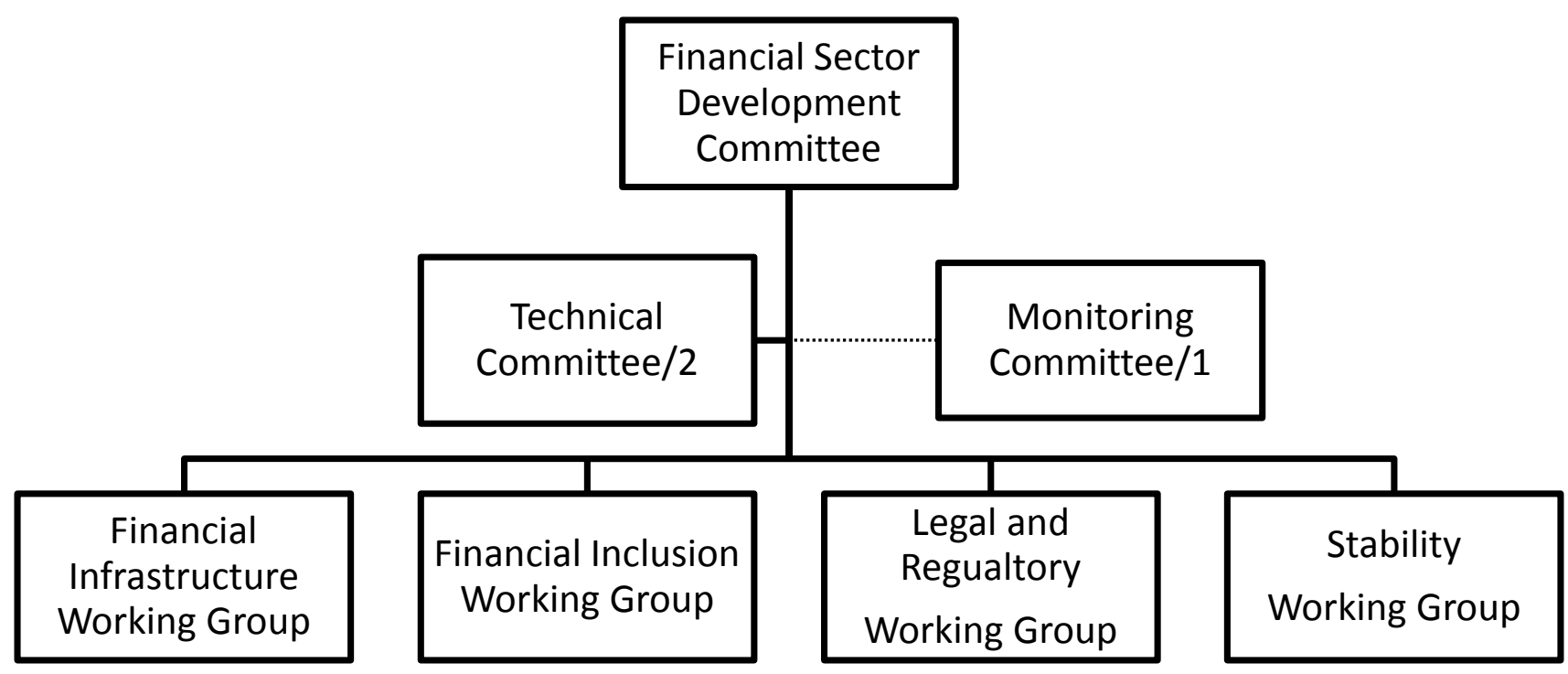

/1 The Monitoring Committee will be chaired by the Governor and comprised of the various Department representatives responsible for implementation of the reforms.

/2 The Technical Committee integrates the different working groups under the guidance of a Coordinator. 


\section{a. Monitoring and Evaluation}

111. The Secretariat and the Technical Committee will be responsible for the oversight, coordination and implementation of the strategy. Much of the work will require the active participation of private and public sector, financial institutions as well as other public and private non-financial entities. These institutions will be an essential part of the thematic working groups and implementation of the strategy.

To facilitate progress each working group should report its progress semi-annually to the FSDIP Secretariat. The Financial Sector Development Committee will prepare an annual report on its activities and progress towards the KPIs, which will be based on the action plan below (and developed at a later stage in this project cycle). In addition to this reporting on activities completed, a strong measurement and evaluation system is needed to track progress relative to the objectives and KPIs of this strategy. This will aid in the identification of successful programs that can be replicated, obstacles that need to be removed, unintended consequences that result and/or tactical re-adjustments of the strategy as needed.

\section{b. Action Plan}

112. The four objectives: I - Modern Legal and Regulatory Framework; II - Sound and Stable Financial System; III - Robust and Efficient Financial Infrastructure; IV - Broader Financial Inclusion will be achieved through a multi-stakeholder action plan coordinated by the FSDIP Secretariat. The action plan incorporates key performance indicators based on a gap analysis of the supplyside and legal/regulatory reviews completed in 2014/15.

113. To achieve these four objectives, the FSDIP action plan is structured around three key strategic areas in the financial sector: Strengthening Financial Sector Supervision, Increasing Financial Inclusion, and Upgrading Financial Infrastructure, while also including a general strategic area. Strategic Area A, Strengthening Financial Sector Supervision, centers around establishing a coherent, comprehensive and harmonized legal and regulatory framework for the financial sector, enhancing oversight capacity and resolution. Strategic Area B, Increasing Financial Inclusion, concentrates on microfinance consumer protection, non-banch banking, assessing MSMEs financing constraints, and reviewing other legislation related to access to financial services. Strategic Area C, Upgrading Financial Infrastructure, focuses on establishing a card payment and a secured transaction system, improving credit registry and reporting, and analyzing government bonds. Strategic Area $D$ focuses on interventions outside the scope of the Strategic Areas A to $C$, including enhancing the judicial review process for commercial and financial transactions and develop strong auditing and accounting infrastructure and standards.

114. All recommendations are categorized by priority, a corresponding timeframe, and implementation status. Prioritization levels include high, medium, and low. Timeframes provide the recommended window of time within which to undertake the recommendation. These 
timeframes vary across prioritization levels due to the particular nature and thus requisite time of each reform. The timeframes range from 1-6 to 36-60 months. Within each Strategic Area, the recommendations are sequenced by priority and the corresponding timeframe to strategically sequence the reforms in a manner that permits, recommendations to be promote simultaneously across strategic areas. The matrix in Annex I provides a more detailed and complete list of actions needed. The action matrix is prioritized, identifies the timeframe for actions, and outlines the status. 


\section{Annex 1: Action Matrix}

\begin{tabular}{|c|c|c|c|c|c|c|}
\hline \multicolumn{7}{|c|}{ Strategic Area A: Strengthen Financial Sector Supervision } \\
\hline No. & Recommendation & Priority & Status & Timeframe & Agency & Partner \\
\hline 1 & $\begin{array}{l}\text { Establish a coherent, comprehensive and harmonized legal and regulatory } \\
\text { framework } \\
\text { for the financial sector and amend new legislation where pertinent. Specifically, } \\
\text { finalize amendments to the Central Bank Act and Financial Institutions Law and } \\
\text { update rules and regulations in accordance with the new law. Make all relevant laws, } \\
\text { rules and regulations available on government websites. }\end{array}$ & High & $\begin{array}{l}\text { Partially } \\
\text { started }\end{array}$ & $\begin{array}{l}\text { 6-12 } \\
\text { months }\end{array}$ & BCSTP & WBG, IMF \\
\hline 2 (a) & $\begin{array}{l}\text { Enhance supervisory capacity for both off- and on-site supervision by increasing } \\
\text { frequency and robustness of on-site risk-based examinations of banks by } \\
\text { implementing a schedule for more frequent examinations of banks. Provide } \\
\text { additional staff to banking supervision department. }\end{array}$ & Medium & Started & Ongoing & $\begin{array}{l}\text { BCSTP } \\
\text { (BSD) }\end{array}$ & $\begin{array}{l}\text { IMF, } \\
\text { WBG }\end{array}$ \\
\hline 2 (b) & $\begin{array}{l}\text { Increase use of data currently gathered on the banking sector to inform analysis and } \\
\text { supervision of banking sector. In particular, there is a need to conduct an asset quality } \\
\text { review of banks and to analyze key trends and risks to the sector, such as financial } \\
\text { stability. }\end{array}$ & High & Started & $\begin{array}{l}\text { First } 6 \\
\text { months }\end{array}$ & BCSTP & IMF \\
\hline 2 (c) & Conduct a detailed assessment of banks compliance with Basel Core Principles. & Medium & $\begin{array}{l}\text { Not } \\
\text { started }\end{array}$ & $\begin{array}{l}12-18 \\
\text { months }\end{array}$ & BCSTP & $\begin{array}{l}\text { IMF, } \\
\text { WBG }\end{array}$ \\
\hline $2(d)$ & $\begin{array}{l}\text { Review arrangements for cross border banking supervision and home-host } \\
\text { cooperation. }\end{array}$ & Low & $\begin{array}{l}\text { Not } \\
\text { started }\end{array}$ & $\begin{array}{l}12-18 \\
\text { months }\end{array}$ & BCSTP & $\begin{array}{l}\text { IMF, } \\
\text { WBG }\end{array}$ \\
\hline $2(\mathrm{e})$ & $\begin{array}{l}\text { Review and revise bank licensing procedures to ensure due diligence for new bank(s) } \\
\text { entering the country and appropriate fit and proper guidelines and regulations. }\end{array}$ & Low & $\begin{array}{l}\text { Not } \\
\text { started }\end{array}$ & $\begin{array}{l}12-18 \\
\text { months }\end{array}$ & BCSTP & $\begin{array}{l}\text { IMF, } \\
\text { WBG }\end{array}$ \\
\hline 3 (a) & $\begin{array}{l}\text { Conduct a comprehensive review of the regulatory framework necessary to } \\
\text { implement the new Bank Resolution Law, including specific guidelines for the } \\
\text { resolution of distressed financial institutions. }\end{array}$ & High & $\begin{array}{l}\text { Partially } \\
\text { started }\end{array}$ & $\begin{array}{l}1-6 \\
\text { months }\end{array}$ & BCSTP & WBG, IMF \\
\hline $3(b)$ & $\begin{array}{l}\text { Strengthen regulatory framework for prompt corrective actions, improve } \\
\text { contingency planning and establish coordination mechanisms for crisis management. }\end{array}$ & Medium & $\begin{array}{l}\text { Partially } \\
\text { started }\end{array}$ & $\begin{array}{l}6-12 \\
\text { months }\end{array}$ & BCSTP & $\begin{array}{l}\text { WBG, } \\
\text { IMF }\end{array}$ \\
\hline Stra & c Area B: Increase Financial Inclusion & & & & & \\
\hline No. & Recommendation & Priority & Status & Target & Agency & Partner \\
\hline 4 (a) & $\begin{array}{l}\text { Finalize preparation of draft Microfinance Law and corresponding rules and } \\
\text { regulations. }\end{array}$ & Medium & $\begin{array}{l}\text { Partially } \\
\text { started }\end{array}$ & $\begin{array}{l}12-18 \\
\text { months }\end{array}$ & $\begin{array}{l}\text { BCSTP } \\
\text { (Legal) }\end{array}$ & WBG \\
\hline $4(b)$ & $\begin{array}{l}\text { Bring microfinance institutions and consumer lenders under central bank market } \\
\text { conduct and prudential supervision and ensure that they participate in the central } \\
\text { credit registry. }\end{array}$ & High & $\begin{array}{l}\text { Partially } \\
\text { started }\end{array}$ & $\begin{array}{l}1-6 \\
\text { months }\end{array}$ & $\begin{array}{l}\text { BCSTP } \\
\text { (Legal) }\end{array}$ & WBG \\
\hline
\end{tabular}




\begin{tabular}{|c|c|c|c|c|c|c|}
\hline 4 (c) & $\begin{array}{l}\text { Implement market conduct and consumer protection standards for transparency of } \\
\text { financial products and interest rates by reviewing joint orders and other publications, } \\
\text { where such information is published. }\end{array}$ & Medium & $\begin{array}{l}\text { Not } \\
\text { started }\end{array}$ & $\begin{array}{l}\text { 6-12 } \\
\text { months }\end{array}$ & $\begin{array}{l}\text { BCSTP } \\
\text { (Market } \\
\text { Conduct) }\end{array}$ & WBG \\
\hline $5(a)$ & $\begin{array}{l}\text { Issue guidelines to facilitate mobile money as a low cost access channel (initially for } \\
\text { payments and savings only). Amend legislative and regulatory framework, if } \\
\text { necessary. }\end{array}$ & Medium & $\begin{array}{l}\text { Not } \\
\text { started }\end{array}$ & $\begin{array}{l}\text { 6-12 } \\
\text { months }\end{array}$ & $\begin{array}{l}\text { BCSTP } \\
\text { (Legal) }\end{array}$ & ADB \\
\hline 5 (b) & $\begin{array}{l}\text { Permit agent banking among financial institutions by allowing banks to partner with } \\
\text { local firms as banking agents. }\end{array}$ & Medium & $\begin{array}{l}\text { Not } \\
\text { started }\end{array}$ & $\begin{array}{l}6-12 \\
\text { months }\end{array}$ & BCSTP & ADB \\
\hline $5(c)$ & $\begin{array}{l}\text { Promote G2P and other bulk and recurrent payments, such as civil service salaries, as } \\
\text { an avenue to encourage consumers to utilize bank accounts and to enhance } \\
\text { competition in the banking sector. Additionally, promote the use of digital financial } \\
\text { services to facilitate these payments to further promote financial inclusion. }\end{array}$ & Medium & $\begin{array}{l}\text { Not } \\
\text { started }\end{array}$ & $\begin{array}{l}9-18 \\
\text { months }\end{array}$ & MOF & ADB \\
\hline \multirow{2}{*}{$6(\mathrm{a})$} & $\begin{array}{l}\text { Conduct an enterprise survey to identify financing constraints for businesses in order } \\
\text { to promote access to finance for MSMEs. }\end{array}$ & Medium & $\begin{array}{l}\text { Not } \\
\text { started }\end{array}$ & $\begin{array}{l}12-24 \\
\text { months }\end{array}$ & MOF & WBG \\
\hline & $\begin{array}{l}\text { Institute regulatory requirements that lenders consider a borrower's capacity to } \\
\text { repay and existing debts in loan decisions. }\end{array}$ & Medium & $\begin{array}{l}\text { Not } \\
\text { started }\end{array}$ & $\begin{array}{l}12-24 \\
\text { months }\end{array}$ & BCSTP & WBG \\
\hline $6(c)$ & Review the functionality of mandatory auto insurance. & Low & $\begin{array}{l}\text { Not } \\
\text { started }\end{array}$ & $\begin{array}{l}12-24 \\
\text { months }\end{array}$ & BCSTP & WBG \\
\hline \multicolumn{7}{|c|}{ Strategic Area C: Upgrade Financial Infrastructure } \\
\hline No. & Recommendation & Priority & Status & Target & Agency & Partner \\
\hline 7 & $\begin{array}{l}\text { Implement a fully interoperable card payment system with international linkages } \\
\text { following a diagnostic of current payments infrastructure. }\end{array}$ & High & $\begin{array}{l}\text { Not } \\
\text { started }\end{array}$ & $\begin{array}{l}6-12 \\
\text { months }\end{array}$ & BCSTP & $\begin{array}{l}\text { ADB, } \\
\text { WBG }\end{array}$ \\
\hline 8 (a) & $\begin{array}{l}\text { Enhance existing credit registry with historical data, positive information on clients, } \\
\text { multi-borrowing/concentration statistics, data from consumer lenders and the status } \\
\text { of loans. }\end{array}$ & High & $\begin{array}{l}\text { Partially } \\
\text { started }\end{array}$ & $\begin{array}{l}\text { 6-12 } \\
\text { months }\end{array}$ & BCSTP & ADB \\
\hline 8 (b) & $\begin{array}{l}\text { Research the potential impact of making data contributions mandatory to the credit } \\
\text { reporting system through discussions with local stakeholders and studying this } \\
\text { requirement in other countries. }\end{array}$ & Low & $\begin{array}{l}\text { Not } \\
\text { started }\end{array}$ & $\begin{array}{l}\text { 12-24 } \\
\text { months }\end{array}$ & BCSTP & ADB \\
\hline 8 (c) & $\begin{array}{l}\text { Implement a comprehensive legal framework for credit reporting and a } \\
\text { comprehensive credit information system (positive and negative), which is available } \\
\text { on all formal borrowers from banks, MFIs, payday lenders and utilities. }\end{array}$ & Medium & $\begin{array}{l}\text { Partially } \\
\text { started }\end{array}$ & $\begin{array}{l}\text { 12-24 } \\
\text { months }\end{array}$ & BCSTP & WBG \\
\hline \multirow{2}{*}{$\begin{array}{l}9 \text { (a) } \\
9 \text { (b) }\end{array}$} & $\begin{array}{l}\text { Pass a modern legal framework for secured transactions and electronic collateral } \\
\text { registry in place. }\end{array}$ & High & $\begin{array}{l}\text { Not } \\
\text { started }\end{array}$ & $\begin{array}{l}6-12 \\
\text { months }\end{array}$ & $\begin{array}{l}\text { MOF, } \\
\text { BCSTP }\end{array}$ & WBG \\
\hline & $\begin{array}{l}\text { Implement an electronic movable and immovable collateral registry by creating a } \\
\text { modern secured transactions law. }\end{array}$ & Medium & $\begin{array}{l}\text { Not } \\
\text { started }\end{array}$ & $\begin{array}{l}\text { 6-12 } \\
\text { months }\end{array}$ & $\begin{array}{l}\text { MOF, } \\
\text { BCSTP }\end{array}$ & WBG \\
\hline 9 (c) & $\begin{array}{l}\text { Train businesses and lenders on suitable collateral guarantees and the secured } \\
\text { transaction law once it passes. }\end{array}$ & Medium & $\begin{array}{l}\text { Not } \\
\text { started }\end{array}$ & $\begin{array}{l}9-18 \\
\text { months }\end{array}$ & MOJ & $\begin{array}{l}\text { WBG, } \\
\text { UNDP }\end{array}$ \\
\hline
\end{tabular}




\begin{tabular}{|c|c|c|c|c|c|c|}
\hline 10 & $\begin{array}{l}\text { In the context of government borrowing needs, explore the development of } \\
\text { government bonds and their linkages to monetary policy through dialogue with } \\
\text { government stakeholder. }\end{array}$ & Low & $\begin{array}{l}\text { Not } \\
\text { started }\end{array}$ & $\begin{array}{l}\text { 12-24 } \\
\text { months }\end{array}$ & $\begin{array}{l}\text { MOF/ } \\
\text { BCSTP }\end{array}$ & IMF \\
\hline \multicolumn{7}{|c|}{ Strategic Area D: General Financial Sector } \\
\hline No. & Recommendation & Priority & Status & Target & Agency & Partner \\
\hline 11 (a) & $\begin{array}{l}\text { Revise the judicial review process for commercial and financial transactions, including } \\
\text { execution of collateral guarantees and registration of collateral. }\end{array}$ & High & $\begin{array}{l}\text { Not } \\
\text { started }\end{array}$ & $\begin{array}{l}\text { 6-12 } \\
\text { months }\end{array}$ & MOJ & UNDP \\
\hline $11(b)$ & $\begin{array}{l}\text { Train judges on commercial and financial adjudication techniques. Streamline } \\
\text { adjudication for small claims. Institute alternative dispute resolution mechanisms } \\
\text { and arbitration. }\end{array}$ & Medium & $\begin{array}{l}\text { Not } \\
\text { started }\end{array}$ & $\begin{array}{l}\text { 6-12 } \\
\text { months }\end{array}$ & MOJ & UNDP \\
\hline 12 (a) & $\begin{array}{l}\text { Develop strong auditing and accounting infrastructure and standards by establishing } \\
\text { OTOCA (professional accountancy organization), creating legislation stipulating } \\
\text { auditing standards, and updating chart of accounts. }\end{array}$ & Medium & $\begin{array}{l}\text { Not } \\
\text { started }\end{array}$ & $\begin{array}{l}\text { 6-12 } \\
\text { months }\end{array}$ & MOF & WBG \\
\hline 12 (b) & Task OTOCA to train MSMEs on accounting and finance statement preparation. & Medium & $\begin{array}{l}\text { Not } \\
\text { started }\end{array}$ & $\begin{array}{l}6-12 \\
\text { months }\end{array}$ & MOF & WBG \\
\hline 13 & $\begin{array}{l}\text { Explore potential for further cooperation with Portuguese-speaking countries on the } \\
\text { various recommendations, including assessing the compatibility and feasibility of } \\
\text { adopting effective laws, practices, and systems from Lusophone countries. }\end{array}$ & High & $\begin{array}{l}\text { Not } \\
\text { started }\end{array}$ & $\begin{array}{l}1-6 \\
\text { months }\end{array}$ & & WBG \\
\hline
\end{tabular}




\section{Annex 2: Ongoing Donor Support to STP's Financial Sector}

\begin{tabular}{|c|c|c|}
\hline Strategic Area & Partner & Project description \\
\hline \multirow{4}{*}{$\begin{array}{l}\text { a) Strengthen Financial Sector } \\
\text { Supervision }\end{array}$} & IMF & Central Bank Law amendment \\
\hline & IMF & MCM TA to Banking Supervision Department on Risk-Based Supervision/1 \\
\hline & WBG & Bank Resolution and Crisis Management Regulations/Guidelines \\
\hline & Portugal C.B. & Bank Supervision TA \\
\hline \multirow[t]{2}{*}{ b) Increase Financial Inclusion } & WBG & Access to Finance Pillar in Development Policy Operation (proposed) \\
\hline & AfDB & National Financial Inclusion Strategy (proposed) \\
\hline \multirow[t]{3}{*}{$\begin{array}{l}\text { C) Upgrade } \\
\text { Infrastructure }\end{array}$} & AfDB & $\begin{array}{l}\text { Payments infrastructure upgrade (with WBG support for diagnostic and scoping } \\
\text { of existing payments system) }\end{array}$ \\
\hline & ADB & Economic and Financial Management Support Program \\
\hline & WBG & Secured Transactions Law and Movable Collateral Registry (proposed) \\
\hline d) General Financial Sector & UNDP & $\begin{array}{l}\text { Judicial Reform Program (including training for judges on commercial and } \\
\text { financial issues) }\end{array}$ \\
\hline
\end{tabular}




\section{Annex 3: Consultation \& Dissemination Plan}

The São Tomé e Príncipe Financial Sector Development Implementation Plan is the product of extensive consultations with local stakeholders. Between September 2014 and December 2015, the World Bank undertook four missions to STP (September 2014, January 2015, July 2015, and December 2015) to provide implementation support for the FSDIP, including consultations with stakeholders.

The main objectives of September 2014 mission were to: engage with the Ministry of Finance, BCSTP and other stakeholders to discuss FSDIP objectives, collect the relevant information for the necessary analytical work, take stock of previous activities related to financial sector development in São Tomé and Príncipe, and develop a preliminary work plan. At the conclusion of this mission the team delivered a presentation to the Central Bank Governor and senior officials containing the main conclusions and proposed implementation plan for the project.

A mission team returned to STP in January 2015 to: (1) engage BCSTP, Ministry of Finance and other stakeholders on the main issues relevant to financial sector development; (2) conduct a diagnostic of the banking sector, financial inclusion environment and the legal and regulatory framework of the financial sector; and; (3) carry out a technical review of the existing credit registry and the potential for a movable collateral registry.

The December 2014 mission set in motion the creation of a governance framework to aid in the drafting and development of the Financial Sector Development Implementation Plan (FSDIP). The framework is led by a Financial Sector Development Council. The Council is comprised of the Minister of Finance as chair, the Governor of the BCSTP as vice-chair, and the Ministers of Economy, Justice and other line ministries. A technical team comprised of these same organizations are represented at the National Administrator level are then responsible for managing the implementation of the FSDIP and will oversee thematic ad hoc working groups focused on particularly themes established by the Council. The Council also appoints a FSDIP Secretariat to support the work of the technical team and working groups. 
Figure: FSDIP Governance Framework

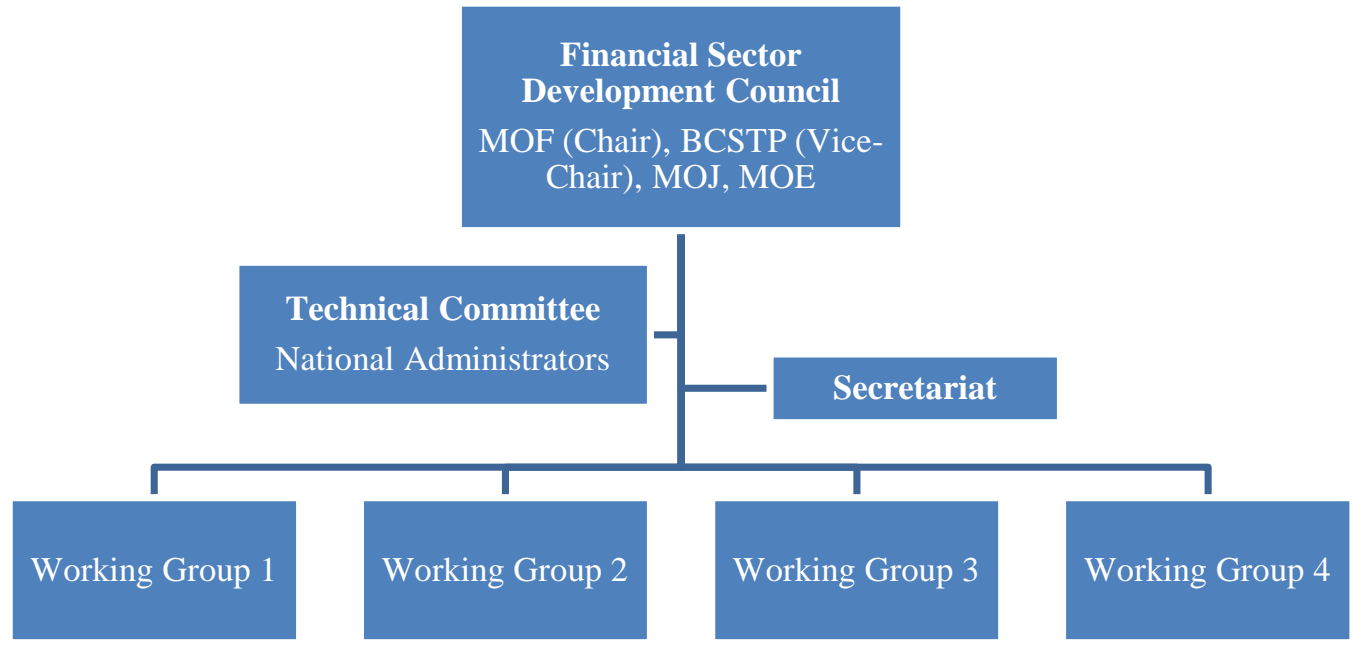

In July 2015, a World Bank mission returned to São Tomé and Príncipe to advance preparation of the FSDIP. The mission discussed the draft FSDIP and participated in a stakeholder workshop with Government, Central Bank, private financial institutions, and civil society. The mission also delivered technical trainings on credit information collection, analysis and quality control for the credit registry and private financial institutions. The mission also met with the Prime Minister, Minister of Finance, BCSTP Governor and senior staff, and representatives of various private financial institutions, investors, associations, and NGOs. After the mission, the team incorporated client feedback and the results of the stakeholder workshop, and also held a quality review of the FSDIP in October 2015.

In December 2015, a mission returned to STP to finalize preparation of the FSDIP. The mission discussed the draft FSDIP with the Minister of Finance, the Minister of Economy and International Cooperation, BCSTP Governor and senior staff, representatives of private financial institutions, and foreign investors. A complete mission agenda is attached.

Since the December 2015 mission, the FSDIP has undergone an initial review at the World Bank and the team is in the process of incorporating the comments. This draft will then undergo a management review scheduled for early March 2016 before it is then sent to the requisite STP stakeholders for additional comments. After this review process is completed, the World Bank aims to disseminate FDSIP in STP in June/July 2016. 


\section{Annex 4: Select Financial Soundness Indicators, 2011-2015}

\begin{tabular}{|c|c|c|c|c|c|}
\hline Capital Adequacy & 2011 & 2012 & 2013 & 2014 & 2015 \\
\hline Capital (net worth) to risk weighted assets & 27.7 & 20.3 & 22.7 & 22.6 & 24.1 \\
\hline Percentage of banks greater or equal to 10 percent & 100.0 & 87.5 & 75.0 & 75.0 & 85.7 \\
\hline Percentage of banks $<10$ and $>6$ percent minimum & 0.0 & 0.0 & 12.5 & 12.5 & 0.0 \\
\hline Percentage of banks below 6 percent minimum & 0.0 & 12.5 & 12.5 & 12.5 & 14.3 \\
\hline Deposits w/banks below 6\% (Dobra billion ) & 0.0 & 83.2 & 59.0 & 325.1 & 455.3 \\
\hline Deposits w/banks below $6 \%$ (USD million ) & 0.0 & 3.8 & 2.7 & 14.7 & 20.6 \\
\hline Capital (net worth) to assets & 26.5 & 22.7 & 18.4 & 20.3 & 15.5 \\
\hline Tier 1 Capital Ratio & 74.2 & 75.7 & 67.9 & 71.6 & 61.6 \\
\hline Tier 2 Capital Ratio & 25.8 & 24.3 & 23.6 & 15.0 & 11.7 \\
\hline Asset quality & 2011 & 2012 & 2013 & 2014 & 2015 \\
\hline Past-due loans to gross loans & 33.2 & 66.7 & 30.4 & 36.2 & 35.0 \\
\hline Nonperforming loans (Dobra billion) & 277.9 & 291.9 & 310.2 & 329.1 & 570.5 \\
\hline Nonperforming loans (USD million) & 12.6 & 13.2 & 14.1 & 14.9 & 25.9 \\
\hline Nonperforming loans to total loans & 15.6 & 15.4 & 16.9 & 19.1 & 29.8 \\
\hline Watch-listed loans & 17.5 & 51.3 & 13.6 & 17.2 & 5.2 \\
\hline Impaired assets/gross lending & 4.8 & 6.8 & 9.1 & 9.5 & 17.3 \\
\hline Provisions (Dobra billion) & 214.8 & 241.9 & 512.5 & 345.0 & 515.6 \\
\hline Provision as percent of nonperforming loans & 77.3 & 82.9 & 165.2 & 104.8 & 90.4 \\
\hline Total assets (Dobra billion) & 2,916 & 3,784 & 4,006 & 4,581 & 4,809 \\
\hline Total assets (USD million) & 132 & 171 & 182 & 208 & 218 \\
\hline$\%$ change in total assets over past 12 months & 6.9 & 28.7 & 5.5 & 14.3 & 22.6 \\
\hline Foreign exchange loans to total loans & 0.0 & 57.9 & 53.9 & 46.5 & 42.1 \\
\hline Nonperforming loans by bank (ratio) & 2011 & 2012 & 2013 & 2014 & 2015 \\
\hline BISTP & 17.8 & 16.0 & 13.1 & 13.7 & 19.5 \\
\hline Afriland First Bank & 5.1 & 11.5 & 10.2 & 13.1 & 32.1 \\
\hline Banco Equador & 8.7 & 9.0 & 20.6 & 34.1 & 51.8 \\
\hline Island Bank & 48.5 & 100.0 & 68.8 & 92.9 & - \\
\hline Commercial Bank & 36.6 & 29.6 & 46.3 & 64.9 & 30.4 \\
\hline Ecobank & 7.5 & 8.7 & 8.0 & 5.4 & 6.0 \\
\hline Energy Bank & 20.0 & 14.6 & 51.8 & 10.9 & 50.0 \\
\hline BGFI & 0.0 & 12.7 & 3.5 & 20.7 & 29.1 \\
\hline Earnings and profitability & 2011 & 2012 & 2013 & 2014 & 2015 \\
\hline Net Income to average assets (ROA) & 0.5 & -0.8 & -2.1 & -3.2 & -5.2 \\
\hline Net Income to average capital (ROE) & 1.5 & -3.3 & -9.3 & -15.9 & -27.1 \\
\hline Noninterest expense to gross income & 91.7 & 79.7 & 427.8 & 109.9 & 141.0 \\
\hline Personnel expense to gross income & 24.2 & 24.5 & 32.8 & 38.9 & 39.5 \\
\hline Noninterest income to gross income & 68.2 & 58.3 & 385.2 & 59.7 & 89.5 \\
\hline Net profit (Dobra Billion) & 13.1 & -31.5 & -81.8 & -135.3 & -226.5 \\
\hline Net profit (USD million) & 0.6 & -1.4 & -3.7 & -6.1 & -10.3 \\
\hline Net profit of prior 12 months as $\%$ of avg. total assets & 0.5 & -0.9 & -2.1 & -3.2 & -5.2 \\
\hline Expense(w/amortization \& provisions)/income & 119.3 & 117.8 & 471.1 & 164.5 & 215.9 \\
\hline Net profit (before tax)/net income & 100.0 & 100.0 & 100.0 & 100.0 & \begin{tabular}{|l}
100.0 \\
\end{tabular} \\
\hline Net Interest Margin & 58.1 & 68.4 & 10.0 & 10.7 & 10.7 \\
\hline Net Interest Margin to Gross income & 0.0 & 0.0 & 60.2 & 60.4 & 48.5 \\
\hline
\end{tabular}




\begin{tabular}{|l|l|l|l|l|l|}
\hline Liquidity & $\mathbf{2 0 1 1}$ & $\mathbf{2 0 1 2}$ & $\mathbf{2 0 1 3}$ & $\mathbf{2 0 1 4}$ & $\mathbf{2 0 1 5}$ \\
\hline Liquid assets/total assets & 20.4 & 37.8 & 40.8 & 45.8 & 52.0 \\
\hline Liquid assets/short term liabilities & 36.7 & 61.5 & 39.6 & 72.7 & 72.5 \\
\hline Loan/deposits & 119.5 & 101.7 & 85.8 & 69.6 & 63.5 \\
\hline Liquid Assets/total deposits & 40.0 & 76.9 & 76.2 & 84.5 & 83.1 \\
\hline Loan/total liabilities & 83.0 & 64.7 & 56.3 & 47.3 & 47.1 \\
\hline Excess reserves/broad money & -0.8 & 8.3 & 20.0 & 19.2 & 18.4 \\
\hline Sensitivity to market risk & 2011 & 2012 & 2013 & 2014 & 2015 \\
\hline Foreign exchange liabilities/total liabilities & 35.0 & 30.8 & 27.0 & 28.1 & 30.0 \\
\hline Foreign exchange liabilities to shareholders funds & 97.0 & 105.0 & 119.3 & 110.3 & 162.8 \\
\hline Foreign currency deposits/official reserves & 84.2 & 84.9 & 65.0 & 69.2 & 65.5 \\
\hline
\end{tabular}

Source: BCSTP 


\section{Annex 5: Small Financial Systems: Some Stylized Facts and Evidence from Sao Tome and Principe}

Prepared by: Dorothe Singer ${ }^{31}$

The challenges of small financial systems are well known. The provision of financial services is often more expensive and more limited in small financial systems compared to larger ones. At the root of those challenges are economies of scale, which can be found both at the level of financial institution and at the level of the financial system as a whole. Many costs in the provision of financial services are essentially fixed. This means that the cost of financial intermediation decreases as the number of transactions, customers, and institutions increases. Fewer transactions and fewer customers thus not only sustain fewer financial institutions and less competition, they also make it more expensive for financial institutions to operate as they face a number of costs including branch network, computer systems, and corporate governance structures that are largely independent of the number of customer served. Similarly, the costs of regulating and supervising a financial system and the cost of payments systems and other financial infrastructure are also largely independent of the number of institutions that make up the financial system. Moreover, it is often difficult for small financial system to diversify risk, which can further constrain the size of the financial system in small markets and contribute to financial stability risks.

Bossone, Honohan, and Long (2002) provide a discussion of how small financial systems differ from larger ones and propose policies that can help small financial systems overcome some of these challenges. In particularly, they show how openness can help offset some of the disadvantages of being small. Work by Beck and De La Torre (2007), Barajas et al. (2013), and Beck and Feyen (2013) benchmarks the size, depth, and performance of financial systems relative to structural characteristics of countries such as size in terms of economic activity and population. They find that poorer countries and countries with smaller populations have smaller, shallower and poorer performing financial sectors.

Against this background, the purpose of this paper is to take stock of how key financial sector indicators vary by financial sector size and summarize policies that can help small financial systems address some of the challenges they face. Given that the financial sector of small financial systems are typically dominated by banks, the analysis here focuses on the banking sector.

The first part of the paper provides an overview of the characteristics of small financial systems and how they differ from larger financial systems along a number of key financial system

\footnotetext{
31 This draft is from October 20, 2015
} 
indicators. The second part of the paper takes a closer look at the structure of one small financial system, Sao Tome and Principe, and factors driving the interest rate spread in this small financial system. The paper concludes with a summary of policy implications for small financial systems.

\section{Countries with small financial systems}

In 2013, 19 countries-out of 170 reporting countries - had a financial system whose total size as measured by M2 (currency outside of banks and demand deposits) is less then USD 1 billion (Figure 1, Table 1). As Bossone, Honohan, and Long (2002) point out, this is no larger than a small bank in a developed country. ${ }^{32}$

Countries with small financial systems are, not surprisingly, characterized by small populations. Among the 19 countries, population size ranges from less than 100,000 in Dominica and the Seychelles to 10 million in Burundi and is on average less than 2 million. They are also, not surprisingly, typically found in small economies as measured by GDP. In terms of GDP per capita, the group of countries varies widely, from low income countries to upper middle income countries. About half of the countries are located in Sub-Saharan Africa (10), followed by East Asia Pacific (6) and Latin American and the Caribbean (3). (Given that a disproportionate number of countries with small population and low GDP per capita do not report M2, the true number of countries with small financial systems is higher than 19.)

Figure 1: Size of Financial System (M2) in 170 countries (in USD billion), 2013

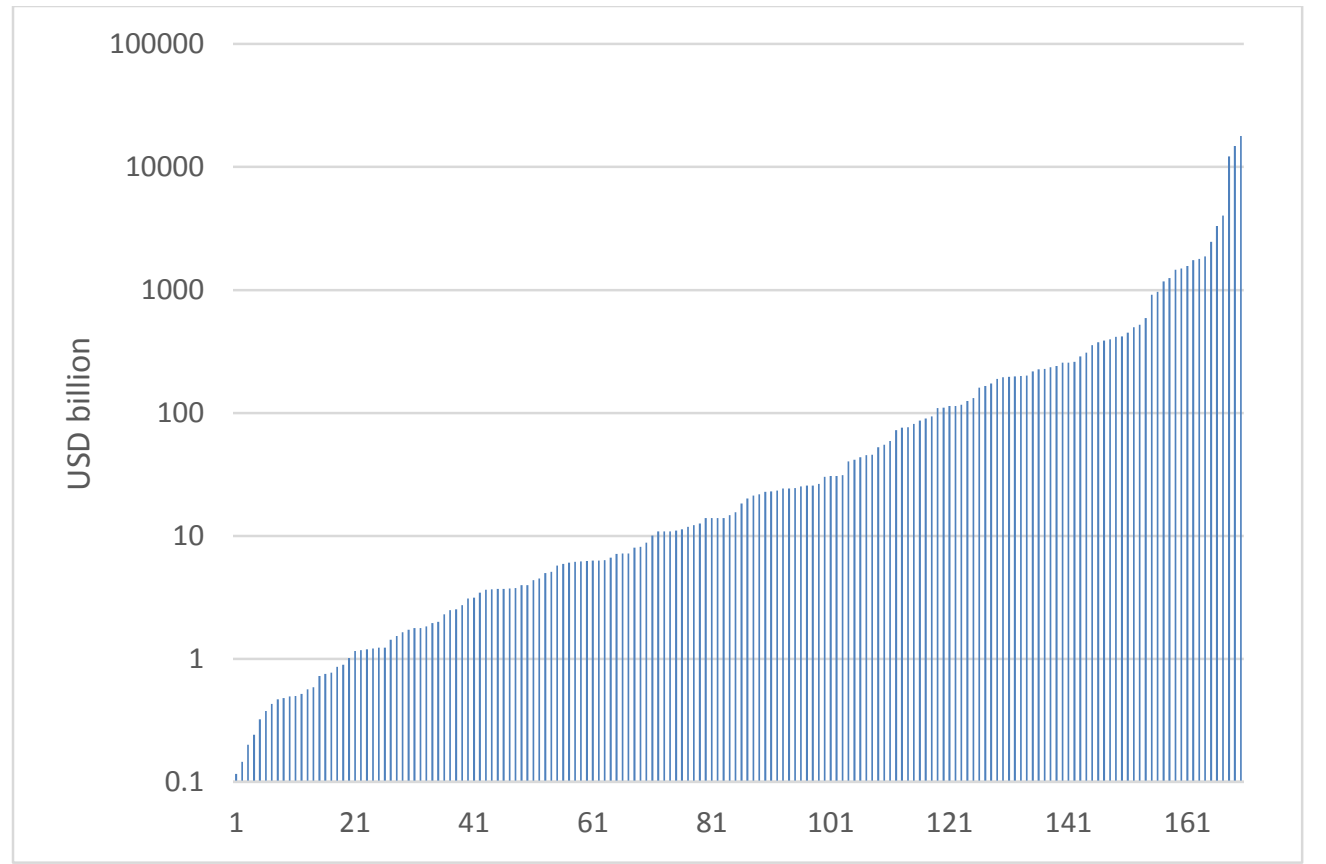

Source: World Development Indicators

\footnotetext{
${ }^{32}$ Adjusted for inflation, USD 1 billion in 1999 is equivalent to USD 1.35 billion in 2013. See also the US Federal Reserve Board's FRED database for the size of US banks.
} 
Table 1: Countries with Financial System Size (M2) of Less than USD 1 Billion, 2013

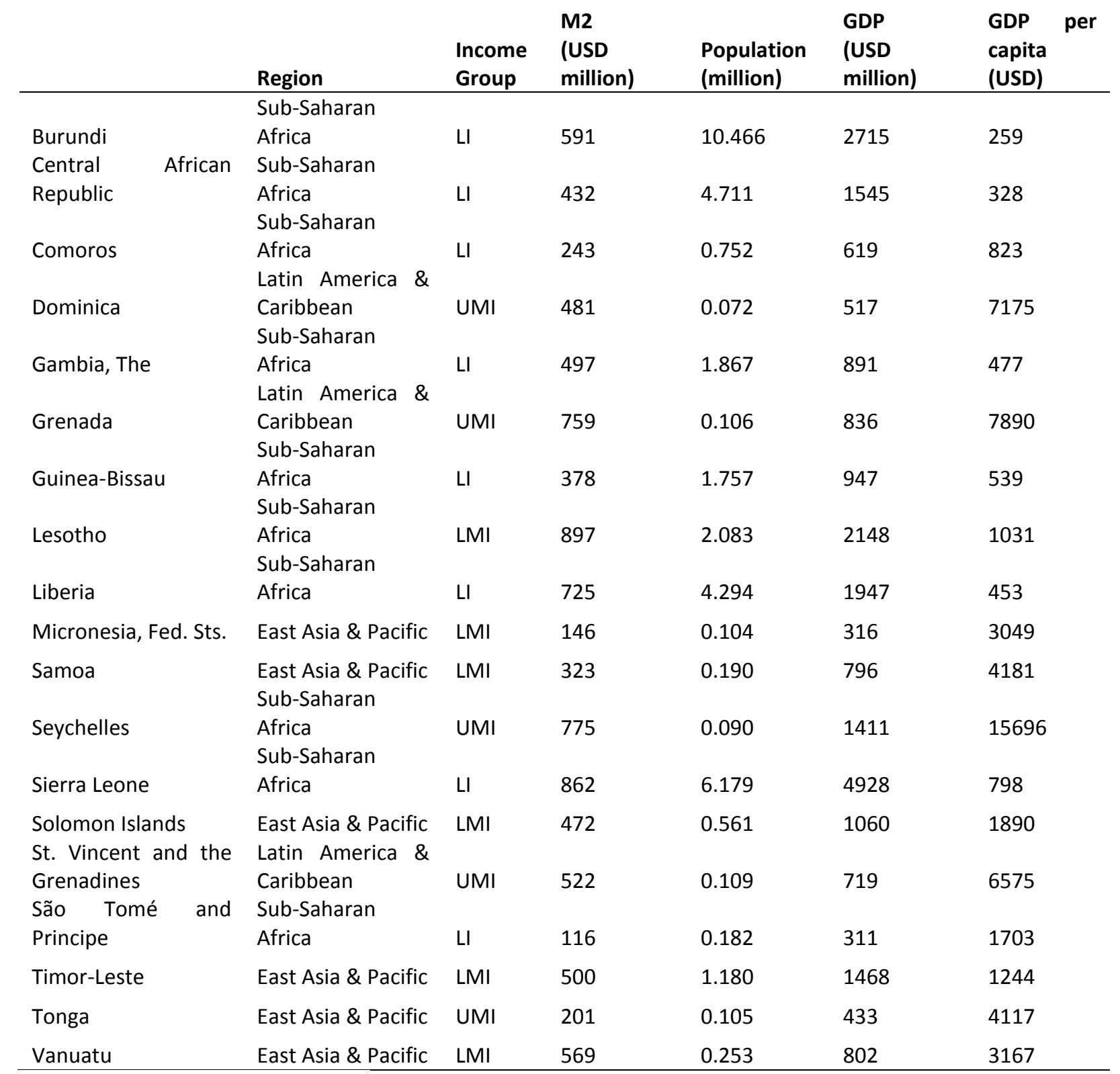

Source: World Development Indicators

Note: Lower income (LI), lower middle income (LMI), upper middle income (UMI).

USD 1 billion is a low threshold. 70 countries out of 170 countries had a financial system of less than USD 10 billion in terms on M2. By comparison, 63 banks in the United States had more than USD 15 billion in average assets at the end of 2013 (US Federal Reserve Bank, FRED database). The average population size for countries with financial systems in terms of M2 between USD 1 billion and USD 10 billion is 7.5 million if excluding Congo, Dem. Rep., which with a population of 72 million is twice as large as the next populous country in this category.

Compared to 10 years ago, the number of countries with financial systems with $M 2$ smaller than USD 10 billion (in 2013 dollars) has decreased from 104 in 2003 to 70 in 2013 (Table 2). As their 
economies have grown and their financial sectors have expanded, some countries moved from having financial systems with M2 below USD 1 billion (in 2013 dollars) to financial systems with M2 between USD 1 billion and USD 10 billion (in 2013 dollars) while in other countries the financial sector now clears the threshold of USD 10 billion. The latter category includes countries with relatively larger population such as Kenya, which have been able to expand the size of their financial system as their economies grew and their financial sectors were liberalized. However, many countries with small financial systems are too small in terms of population to develop large financial systems serving their domestic economy. ${ }^{33}$

Table 2: Countries with Small Financial Systems (M2), 2003 and 2013

\begin{tabular}{lll}
\hline Number of countries with M2 less than USD 10 billion (in 2013 dollars) & 2003 & 2013 \\
of which M2 less than USD 1 billion (in 2013 dollars) & 104 & 70 \\
of which M2 between USD 1 billion to USD 10 billion (in 2013 dollars) & 55 & 19 \\
\hline
\end{tabular}

Source: World Development Indicators

Note: No 2013 data available for four countries (Barbados, Guinea, Lao PDR, and Rwanda) which likely have financial system size of less than USD10 billion in 2013.

Smallness and the issues facing small financial systems are of course not limited to countries falling below some thresholds. Rather, as some of the analysis below shows, the issues facing small financial systems are also relevant to relatively small systems beyond those thresholds along the continuum of size, albeit to a lesser extent.

\section{Stylized facts of small financial system (compared to non-small financial systems)}

This section documents how the banking sectors of small financial systems compare to larger financial systems on key financial indicators for financial depth, structure, capitalization, asset quality, profitability, efficiency, and access. Data for these indicators come from a number of different data sources with varying country coverage, not just across databases but also across variables within the same database. For best coverage, data it typically reported for 2013. Whenever possible, tables that report key indicators by financial system size distinguish between very small ( $M 2$ less than USD 1 billion in 2013) and small (M2 between USD 1 and 10 billion in 2013). For a number of key indicators coverage among "very small" countries is poor; in these cases countries with "very small" and "small" financial systems are reported in one single category. Smaller countries are often more likely to be among non-reporters of indicators; keeping this in mind, reported averages for small financial systems might be biased upwards (biased favorably).

\subsection{Absolute Financial Sector Size and Financial Depth}

\footnotetext{
${ }^{33}$ Some countries with small population have developed large financial sectors through the provision of offshore financial services. However, it is not clear that offshore financial services contribute to the quality of depth of on-shore financial services in small developing economies (Bossone, Honohan, and Long, 2002).
} 
Given the presence of economies of scale, the absolute size of financial system matters. But are small financial systems also small in relative terms? Two common relative measures of the depth of the financial sector are the ratios M2 as a percentage of GDP and private credit extended by the financial systems as a percentage of GDP. A simple scatter plot of private credit as percentage of GDP against size and a tabulation of financial depth by size shows that small financial systems are not only small in absolute terms as measured by $M 2$, but also in relative terms (Figure 2 and Table 3). And while the financial depth of countries with small financial systems in 2013 in absolute terms have increased over the past 10 years, so has the financial depth in countries with larger financial systems. In 2013, very small and small financial systems on average reported a private credit to GDP ratio of around 30 percent. This compares to an average ratio of 45 percent in other developing countries and 101 percent in high-income OECD countries. However, as reflected by the scatter plot of private credit as percentage of GDP against $M 2$, factors other than the absolute size influence financial depth and policy can play a potential role in further deepening financial sectors even for a given absolute size.

Figure 2: Private Credit by Banks (\% GDP) vs. M2, 2013

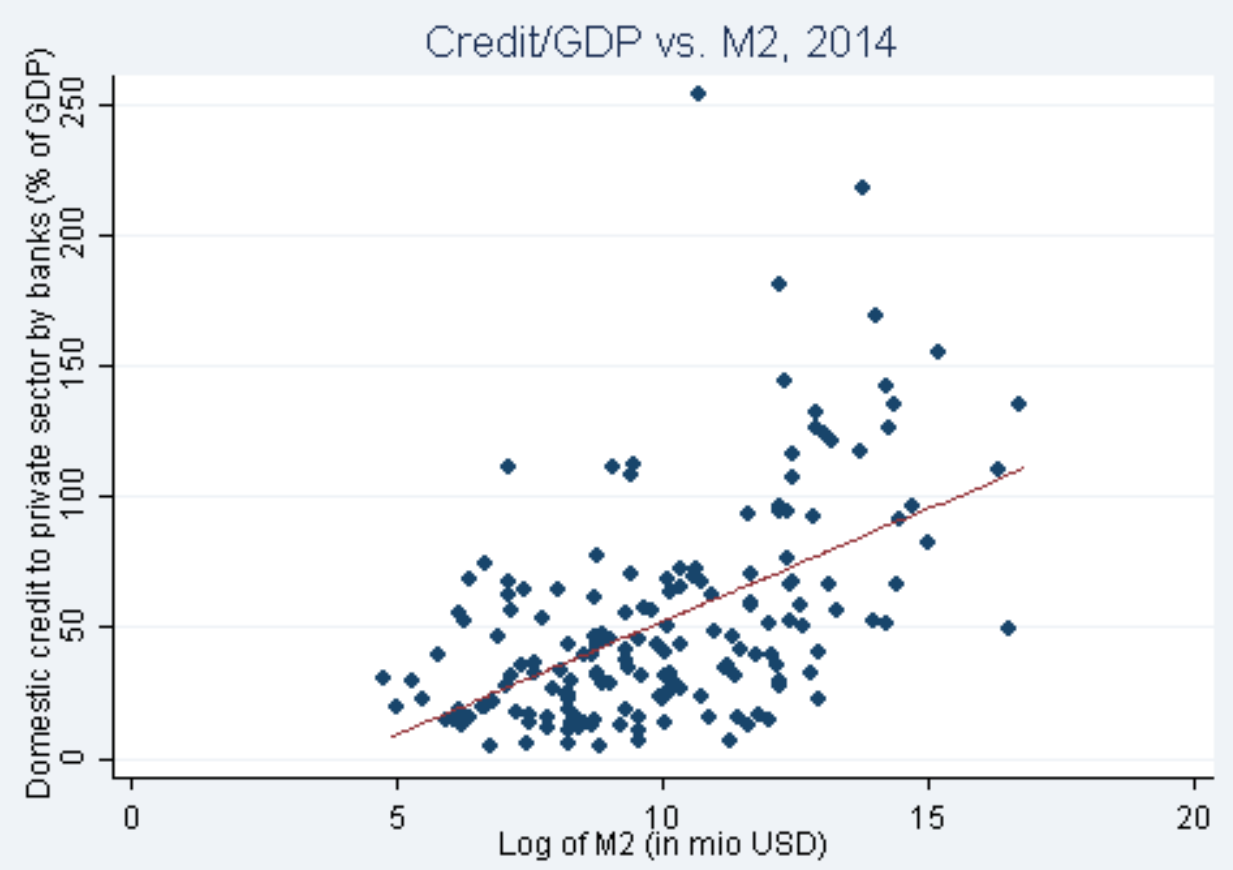

Source: World Development Indicators 
Table 3: Financial System Size and Financial Depth, 2003 and 2013

\begin{tabular}{|c|c|c|c|c|}
\hline & \multicolumn{2}{|c|}{$\mathrm{M} 2$ (as \% of GDP) } & \multicolumn{2}{|c|}{$\begin{array}{l}\text { Private Credit provided by } \\
\text { Banks (as \% of GDP) }\end{array}$} \\
\hline & 2003 & 2013 & 2003 & 2013 \\
\hline Very small (M2 less than USD 1 billion in 2013) & 36.6 & 48.0 & 19.1 & 29.0 \\
\hline $\begin{array}{l}\text { Small ( } M 2 \text { between USD } 1 \text { and } 10 \text { billion in } \\
\text { 2013) } \\
\text { Other developing (M2 more than USD } 10\end{array}$ & 42.7 & 50.5 & 26.3 & 35.2 \\
\hline billion in 2013) & 63.7 & 63.8 & 39.4 & 44.8 \\
\hline High income: OECD & 89.3 & 108.4 & 84.7 & 101.2 \\
\hline
\end{tabular}

Source: World Development Indicators

\subsection{Financial System Structure and Size}

Compared to countries with larger financial systems, small financial systems are characterized by fewer financial institutions and a higher share in the number of foreign institutions and the percentage of total bank assets held by foreign banks (Figure 3). ${ }^{34}$ Given the typically smaller market size of countries with small financial systems in terms of overall population and often also in terms of income, the smaller number of banks is expected. On average, very small and small financial systems have 9 banks compared to 32 banks in other developing countries and 52 banks in high-income OECD countries. The share of foreign banks in the financial system in very small and small financial systems is with 62 percent (number) and 75 percent (assets), respectively, about twice as large as in other developing and high-income OECD countries. The higher share of foreign banks in small financial systems might just be a reflection that any given number of foreign banks leads to very different shares of foreign bank ownership depending on the number domestic institutions. But it can also point to the fact smaller systems are more open because the presence of foreign financial institutions can help small financial systems address some of the challenges they face such as making the system more competitive and efficient by importing knowledge, risk-management skills, governance, access to capital and economies of scale. However, the presence of foreign banks can also raise questions in terms of foreign banks crowding out the market instead of introducing competition, increasing contagion risk, and overwhelming supervisory capacity. ${ }^{35}$

Asset concentration among the three largest banks is highest in very small and small financial systems at 82 percent; it is 55 percent in other developing countries and 70 percent in highincome OECD countries. The scatter plot of asset concentration among the largest three banks and $\mathrm{M} 2$ shows there is a large variation in the concentration ratio across financial systems, again pointing to other influencing factors and the potential role of policy in determining the level of

\footnotetext{
${ }^{34}$ Data on those characteristics for large number of countries (136) is available in Claessen and van Horen's (2014) Bank Ownership Database. The most recent year for which this data is available is 2009.

${ }^{35}$ For an overview of the benefits and risks of foreign banks see for example Beck et al (2014) and for a specific overview as relevant to small financial systems see Bossone, Honohan, and Long (2002).
} 
concentration (Figure 3). Highly concentrated systems are typically thought to be less competitive; however, in small financial systems there might be a trade-off between competition and size given the prevailing economies of scale in finance, which might make relatively higher levels of concentration desirable.

Table 3: Banking System Structure by Financial System Size, 2009

\begin{tabular}{|c|c|c|c|c|c|}
\hline & $\begin{array}{l}\text { Average } \\
\text { number } \\
\text { banks }\end{array}$ & of & $\begin{array}{l}\text { Average } \% \text { of } \\
\text { foreign banks } \\
\text { among } \\
\text { number } \\
\text { banks }\end{array}$ & $\begin{array}{l}\text { Average } \\
\text { foreign } \\
\text { assets } \\
\text { total } \\
\text { assets }\end{array}$ & $\begin{array}{r}\% \text { of } \\
\text { bank } \\
\text { among } \\
\text { bank }\end{array}$ \\
\hline Very small and small (M2 less than 10 billion in 2013) & 9 & & $62 \%$ & $75 \%$ & \\
\hline Other developing (M2 more than USD 10 billion in 2013) & 32 & & $38 \%$ & $34 \%$ & \\
\hline High income: OECD & 51 & & $34 \%$ & $31 \%$ & \\
\hline
\end{tabular}

Source: Claessens and van Horen (2014)

Note: 2009 is the most recent year available; data available for 30 countries in the "very small and small" category, 53 countries in the "other developing" category, and 31 countries in the "high income: OECD" category.

Figure 3: 3 Bank Asset Concentration vs. M2, 2013

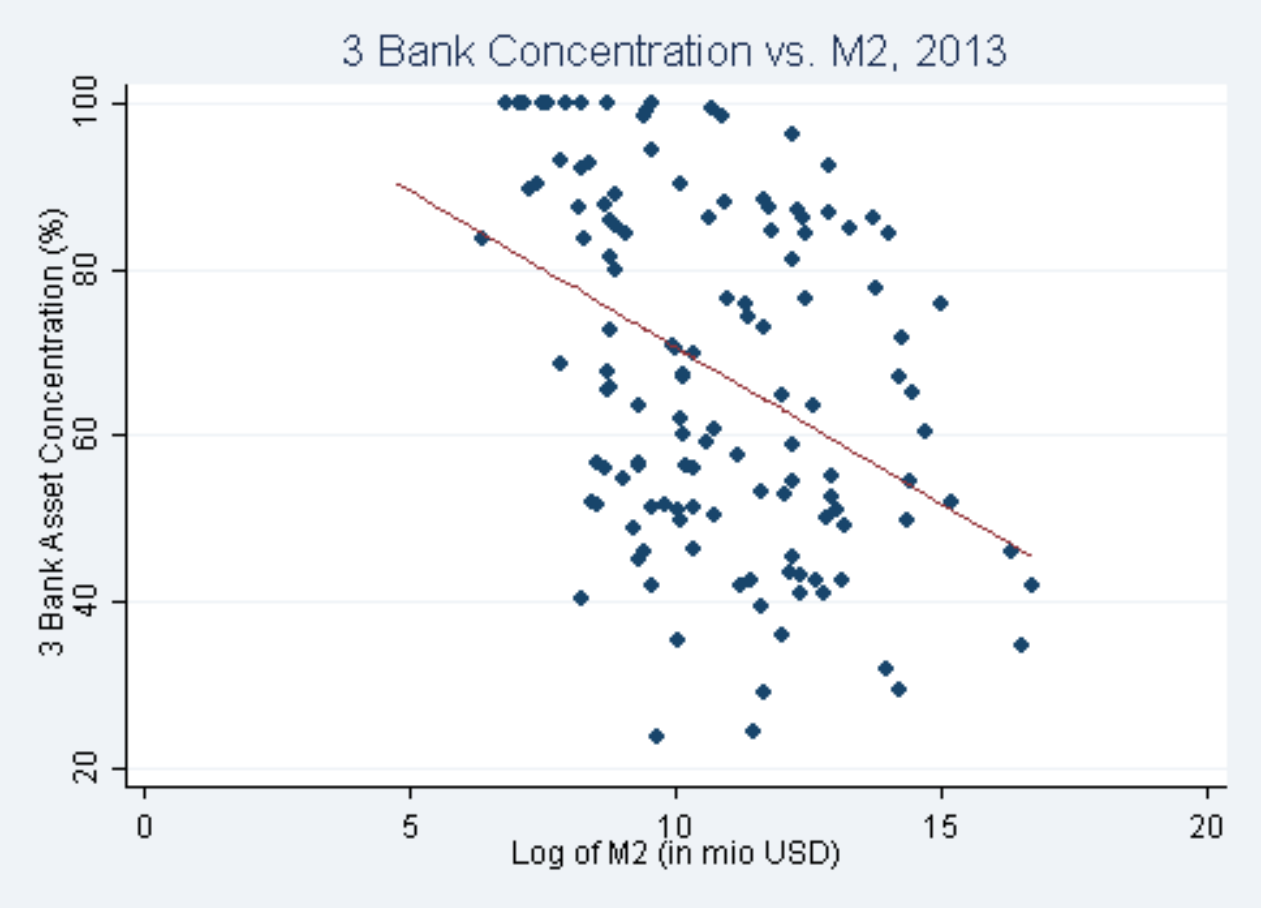

Source: World Development Indicators and Bankscope via FinStats

\subsection{Capital and Asset Quality and Financial System Size}

On average, financial systems across all sizes appear to be well-capitalized. Asset quality in small financial systems is on average somewhat lower than in countries with larger systems (Table 4). 
In 2013, average non-performing loans as percent total gross loans stood at 8.7 percent in countries with very small or small financial systems compared to 7 percent in other developing countries and 5.8 percent in high-income OECD countries. While variation across countries along the size continuum does exist, this relationship is also illustrated in a scatter plot (Figure 4). One factor that might explain higher NPL ratios in very small and small financial systems might be relatively scarcer risk management skills both at the level of banks and at the level of regulation and supervision. It might also be a reflection of the generally greater difficulty to diversify risk in small financial systems.

Table 4: Capital and Asset Quality by Financial System Size, 2013

\begin{tabular}{lllll} 
& $\begin{array}{l}\text { Bank } \\
\text { capital to } \\
\text { assets (\%) }\end{array}$ & $\begin{array}{l}\text { Regulatory } \\
\text { capital to } \\
\text { risk } \\
\text { weighted } \\
\text { assets (\%) }\end{array}$ & $\begin{array}{l}\text { NPLs to } \\
\text { total } \\
\text { gross } \\
\text { loans (\%) }\end{array}$ & $\begin{array}{l}\text { Provisions } \\
\text { to NPLs } \\
\text { (\%) }\end{array}$ \\
\hline Very small and small (M2 less than USD 10 billion in 2013) & 12.4 & 19.3 & 8.7 & 58.6 \\
Other developing (M2 more than USD 10 billion in 2013) & 10.8 & 16.6 & 7.0 & 95.3 \\
High income: OECD & 7.9 & 16.0 & 5.7 & 48.5 \\
\hline
\end{tabular}

Source: IMF Global Financial Stability Report via FinStats

Figure 4: NPL (\% Total Loans) vs. M2, 2013

NPL (\% Total Loans) vs. M2, 2013

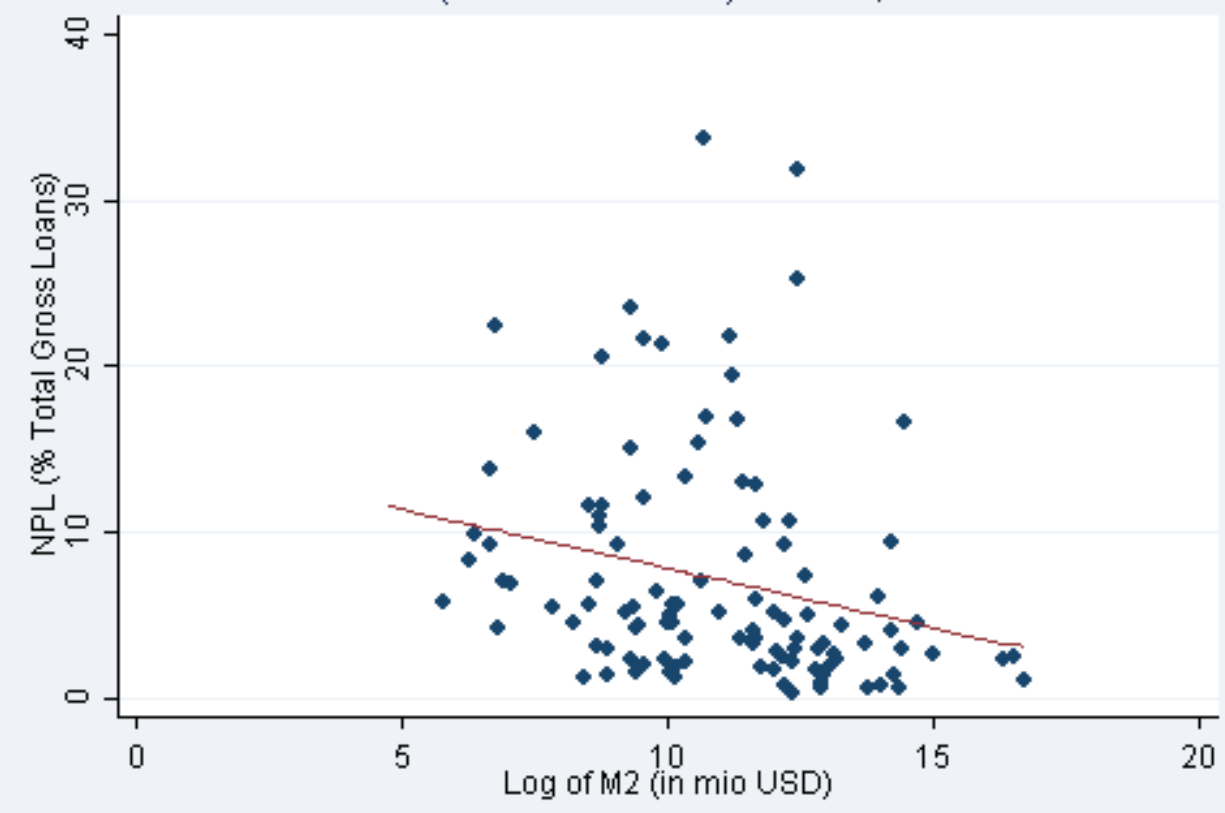

Source: World Development Indicators and IMF Global Financial Stability Report via FinStats

\subsection{Efficiency and Financial Sector Size}


The profitability of banks varies by financial sector size. Return on assets and return on equity in very small financial systems is on average higher than in high-income OECD, but about half that in countries with small financial sectors, which have the highest, average profitability (Table 5). This indicates that contestability remains overall limited especially in small financial systems despite the large share of foreign banks in these countries as documented above.

Operational efficiency in countries with small financial systems is typically lower compared to countries with larger financial systems (Table 5). Given the presence of economies of scale, it comes as no surprise that countries with smaller financial systems have higher cost to income and overhead costs to assets ratios (Figure 5). Interest rate spreads - the difference in lending rate minus deposit rate - are also higher in smaller financial systems and decrease as financial system size increases (Figure 6). Higher interest spreads might reflect higher lending risk, but also the higher overhead costs typically found in smaller financial system. Other factors, including statutory reserve ratios and provisioning requirements, also explain differences in interest rate spreads. More detailed data is needed for an interest rate spread decomposition than is readily available at the international level. The case study of Sao Tome and Principe below sheds light on the main drivers of the interest rate spread in one small financial system.

Higher interest rate spreads in small financial systems might also explain at least in part average higher net interest margins in small financial systems. In contrast, the ratio non-interest income to total income does not appear to vary systematically with financial system size.

Another measure of efficiency is the rate at which the banks are able to transform savings into loans. The private credit to deposits ratio is lower in countries with very small financial systems compared to the ratio in countries with small financial systems and other developing countries. This might be a reflection that banks perceive lending exposure as relatively more risky in these countries, but it could also be a reflection of more limited supply of projects to invest in or a combination of both.

Table 5: Financial Performance Indicators of Banks by Financial System Size (\%), 2013

\begin{tabular}{|c|c|c|c|c|c|c|c|c|}
\hline & $\begin{array}{l}\text { Return } \\
\text { on } \\
\text { assets }\end{array}$ & $\begin{array}{l}\text { Return } \\
\text { on } \\
\text { equity }\end{array}$ & $\begin{array}{l}\text { Private } \\
\text { credit to } \\
\text { deposits }\end{array}$ & $\begin{array}{l}\text { Net } \\
\text { interest } \\
\text { margin }\end{array}$ & $\begin{array}{l}\text { Non- } \\
\text { interest } \\
\text { income } \\
\text { to total } \\
\text { income }\end{array}$ & $\begin{array}{l}\text { Cost to } \\
\text { income }\end{array}$ & $\begin{array}{l}\text { Overhead } \\
\text { costs to } \\
\text { total } \\
\text { assets }\end{array}$ & $\begin{array}{l}\text { Interest } \\
\text { rate } \\
\text { spread }\end{array}$ \\
\hline \multicolumn{9}{|l|}{ Very small (M2 less than } \\
\hline $\begin{array}{l}\text { USD } 1 \text { billion in 2013) } \\
\text { Small (M2 between USD }\end{array}$ & 0.89 & 8.24 & 69.09 & 6.13 & 38.86 & 70.62 & 5.07 & 9.25 \\
\hline $\begin{array}{l}1 \text { and } 10 \text { billion in } 2013 \text { ) } \\
\text { Other developing (M2 } \\
\text { more than USD } 10 \text { billion }\end{array}$ & 1.96 & 16.66 & 85.33 & 5.55 & 40.47 & 56.98 & 4.13 & 9.67 \\
\hline in 2013) & 1.29 & 12.29 & 87.35 & 4.64 & 34.09 & 54.27 & 3.19 & 6.13 \\
\hline High income: OECD & 0.22 & 3.39 & 111.91 & 1.76 & 39.77 & 63.53 & 1.52 & 2.82 \\
\hline
\end{tabular}

Source: World Development Indicators and IMF Global Financial Stability Report via FinStats 
Figure 5: Overheads (\% Total Assets) vs. M2, 2013

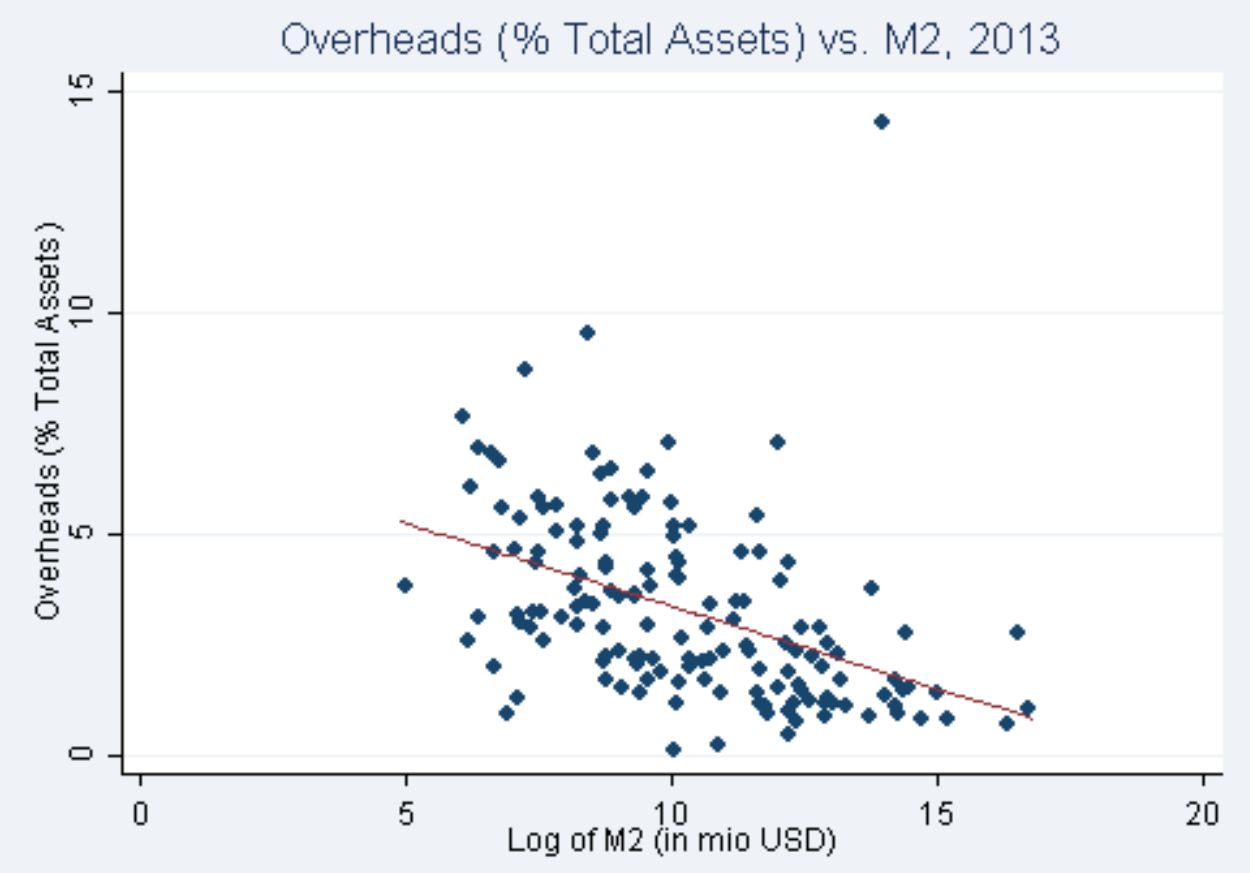

Source: World Development Indicators and IMF Global Financial Stability Report via FinStats

Figure 6: Interest Rate Spread vs. M2, 2013

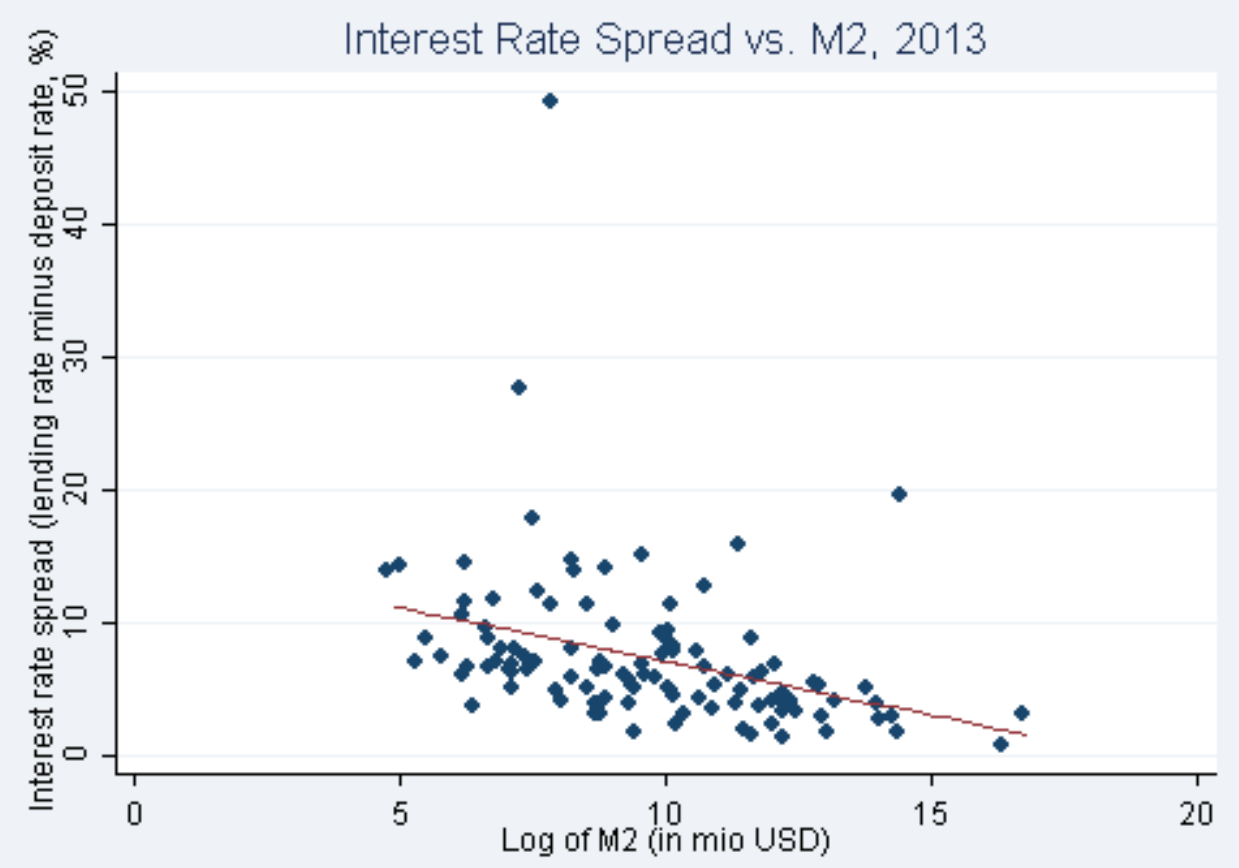

Source: World Development Indicators and IMF Global Financial Stability Report via FinStats 


\subsection{Access}

In terms of access to financial services, smaller financial systems typically have lower account ownership rates among adults and fewer bank branches and ATMs per 100,000 adults (Table 6). A simple average of account ownership rates across countries shows that countries with very small or small financial systems show an account ownership rate of 33 percent among adults compared to one of 48 percent in other developing countries. Data on financial access points show that while differences in bank branches by financial system size in developing countries are relatively small, they are more pronounced for ATMs with on average 22 ATMs per 100,000 adults in very small financial systems, 30 in small financial systems, and 38 in other developing countries. ${ }^{36}$

Table 6: Access Indicators by Financial System Size

\begin{tabular}{|c|c|c|}
\hline \multirow{2}{*}{$\begin{array}{l}2014 \\
\text { Account } \\
\text { ownership } \\
\text { (\% of adults) }\end{array}$} & \multicolumn{2}{|l|}{2013} \\
\hline & $\begin{array}{l}\text { Commercial bank } \\
\text { branches per } \\
100,000 \text { adults }\end{array}$ & $\begin{array}{l}\text { ATMs per } \\
100,000 \text { adults }\end{array}$ \\
\hline & 16 & 22 \\
\hline & 14 & 30 \\
\hline \multicolumn{3}{|l|}{$33 \%$} \\
\hline $48 \%$ & 20 & 38 \\
\hline $93 \%$ & 32 & 94 \\
\hline
\end{tabular}

Very small (M2 less than USD 1 billion in 2013)

Small (M2 between USD 1 and 10 billion in 2013)

Very small and small (M2 less than USD 10 billion in 2013)

$33 \%$

Other developing (M2 more than USD 10 billion in 2013)

$93 \%$

Source: Global Findex database and IMF FAS database

Note: Account ownership calculated as simple averages across countries

\subsection{Other structural information}

There are a number of other structural indicators that would be interesting to compare across different financial system sizes but for which no data is readily available for such comparison:

- $\quad$ Branches vs. subsidiaries

- $\quad$ Currency regime (float, peg, etc.)

- $\quad$ Credit registry

- $\quad$ Presence of informal institutions

- $\quad$ Mobile money presence

\footnotetext{
${ }^{36}$ Data on firm access to financial services is available from the World Bank's Enterprise Surveys but country coverage among very small and small financial systems is too poor to calculate meaningful averages.
} 
- Dollarization

- $\quad$ (Importance of international remittances)

\section{The case of Sao Tome and Principe}

Sao Tome and Principe has one of the smallest financial systems in the world (see Table 1), which is dominated by commercial banks. In 2013, the banking sector consisted of 8 banks, one (majority) domestic owned bank and seven foreign owned banks (Table 7). ${ }^{37}$ The domestic bank, BISTP, came into being in 1993 when the government split the National Bank of Sao Tome and Principe into a separate commercial bank (BISTP) and central bank (BCSTP). BISTP had a monopoly on banking operation in the country until 2003. Banking sector liberalization and the potential for offshore oil led to the entry of foreign banks, however, BISTP remains the dominant institution in the market. BISTP accounts for almost half of Sao Tome and Principe's banking system assets and loans and two-thirds of deposits.

Asset concentration among the three largest banks in the country is high at 73 percent in 2013 and driven by BISTP, the largest bank. This is lower than the average of 82 percent reported above for very small and small financial systems. In contrast to other small financial systems where foreign banks account for $75 \%$ of banking system assets on average (Table 3 ), in Sao Tome and Principe almost half of assets are under majority domestic control and indeed under the control of a single bank.

Table 7: Banking System in Sao Tome and Principe, 2013

\begin{tabular}{lllll} 
& & \multicolumn{2}{c}{ Market Share (\%) } \\
\cline { 3 - 4 } Bank & Majority Ownership & Total Assets & Total Deposits & Gross Loans \\
\hline BISTP & Domestic & $46 \%$ & $68 \%$ & $47 \%$ \\
Equador & Foreign & $14 \%$ & $14 \%$ & $16 \%$ \\
Afriland & Foreign & $13 \%$ & $7 \%$ & $20 \%$ \\
Energy & Foreign & $11 \%$ & $1 \%$ & $5 \%$ \\
BGFI & Foreign & $6 \%$ & $3 \%$ & $3 \%$ \\
Ecobank & Foreign & $6 \%$ & $3 \%$ & $4 \%$ \\
COBSTP & Foreign & $2 \%$ & $1 \%$ & $4 \%$ \\
Island & Foreign & $1 \%$ & $3 \%$ & $1 \%$ \\
\hline Source: BCSTP and own calculations & &
\end{tabular}

The performance of banks in Sao Tome and Principe varies widely. System-wide, a combination of a high rate of non-performing loans, decline in capital adequacy, and a sustained lack of profitability as well as the fact that BCSTP has placed three banks under administration between 2010 and 2015 point to some distress in its system (IMF 2015). In terms on earnings, only two

\footnotetext{
37 In June 2014 Energy Bank acquired the then bankrupt Island Bank.
} 
banks - BISTP and one of the larger foreign banks, Afriland - reported a positive return on assets in 2013 (Table 8). All other institutions reported an operational loss and indeed one of the banks, Island Bank, has gone bankrupt in June 2014 and was acquired by Energy Bank. In January 2015 Banco Equador was placed under administration for repeatedly missing capital requirements. Against this backdrop, it is not surprising that common measures of efficiency provide a mixed picture at best.

Table 8: Financial Performance Indicators for Banks in Sao Tome and Principe, 2013

\begin{tabular}{|c|c|c|c|c|c|c|c|c|}
\hline & $\begin{array}{l}\text { Return on } \\
\text { assets } \\
\text { (before tax) }\end{array}$ & $\begin{array}{l}\text { Return on } \\
\text { equity } \\
\text { (before } \\
\text { tax) }\end{array}$ & $\begin{array}{l}\text { Net } \\
\text { interest } \\
\text { margin } \\
\end{array}$ & $\begin{array}{l}\text { Loans to } \\
\text { deposits }\end{array}$ & $\begin{array}{l}\text { Loans to } \\
\text { assets }\end{array}$ & $\begin{array}{l}\text { Overhead } \\
\text { costs to } \\
\text { assets }\end{array}$ & $\begin{array}{l}\text { Cost to } \\
\text { income } \\
\text { ratio }\end{array}$ & $\begin{array}{l}\text { Non- } \\
\text { interest } \\
\text { income } \\
\text { to total } \\
\text { income }\end{array}$ \\
\hline Afriland & $1 \%$ & $1 \%$ & $4 \%$ & $262 \%$ & $69 \%$ & $5 \%$ & $53 \%$ & $23 \%$ \\
\hline Equador & $-5 \%$ & $-35 \%$ & $1 \%$ & $96 \%$ & $55 \%$ & $11 \%$ & $51 \%$ & $72 \%$ \\
\hline BGFI & $-8 \%$ & $-17 \%$ & $4 \%$ & $68 \%$ & $20 \%$ & $13 \%$ & $3 \%$ & $99 \%$ \\
\hline BISTP & $3 \%$ & $13 \%$ & $7 \%$ & $59 \%$ & $46 \%$ & $7 \%$ & $13 \%$ & $84 \%$ \\
\hline COBSTP & $-1 \%$ & $-1 \%$ & $11 \%$ & $243 \%$ & $75 \%$ & $14 \%$ & $93 \%$ & $22 \%$ \\
\hline Ecobank & $-7 \%$ & $-20 \%$ & $2 \%$ & $117 \%$ & $31 \%$ & $13 \%$ & $138 \%$ & $75 \%$ \\
\hline Energy & $-7 \%$ & $-26 \%$ & $3 \%$ & $457 \%$ & $23 \%$ & $4 \%$ & $50 \%$ & $9 \%$ \\
\hline Island & $-49 \%$ & $27 \%$ & $-12 \%$ & $17 \%$ & $24 \%$ & $51 \%$ & $226 \%$ & $88 \%$ \\
\hline
\end{tabular}

Source: BCSTP and staff calculations

As mentioned above, interest rate spreads are one frequent outcome measure of efficiency and their decomposition, which can be derived from a straightforward accounting identity (see Annex I) can give insights into the extent to which of its components - profits, provisions, overheads, and reserves - contribute to the spread. The interest rate spread in Sao Tome and Principe is at 12.9 percentage points overall higher than the average for countries with very small financial systems (see Table 5) but varies widely across institutions (see Table 9). While the interest rate spread is about 18 percentage points for BISTP, it is less than 1 percent point for Afriland and even negative for Energy Bank. A decomposition of the ex-post interest rate spreads by bank show that profits are the largest component of spreads for BISTP (and for BGFI) while all other banks show significant losses. Overheads are a significant components of interest rate spreads for many banks.

Table 9: Ex-Post Interest Rate Spreads for Banks in Sao Tome and Principe, 2013

\begin{tabular}{llll} 
& $\begin{array}{l}\text { Interest } \\
\text { Rate Spread } \\
\text { (percentage } \\
\text { points) }\end{array}$ & $\begin{array}{l}\text { Deposit } \\
\text { Rate }\end{array}$ & $\begin{array}{l}\text { Lending } \\
\text { Rate }\end{array}$ \\
\hline Afriland & $0.6 \%$ & $10.7 \%$ & $11.3 \%$ \\
Equador & $2.2 \%$ & $9.8 \%$ & $12.0 \%$ \\
BGFI & $18.5 \%$ & $0.4 \%$ & $18.9 \%$ \\
BISTP & $17.6 \%$ & $1.9 \%$ & $19.5 \%$ \\
COBSTP & $26.9 \%$ & $0.2 \%$ & $27.1 \%$
\end{tabular}




\begin{tabular}{llll} 
Ecobank & $6.4 \%$ & $1.6 \%$ & $8.0 \%$ \\
Energy & $-11.4 \%$ & $79.1 \%$ & $67.7 \%$ \\
Island & $5.0 \%$ & $10.8 \%$ & $15.7 \%$ \\
\hline System & $12.9 \%$ & $4.6 \%$ & $17.5 \%$
\end{tabular}

Source: BCSTP and own calculations

Figure 7: Interest Rate Spread Decomposition for Banks in Sao Tome and Principe, 2013

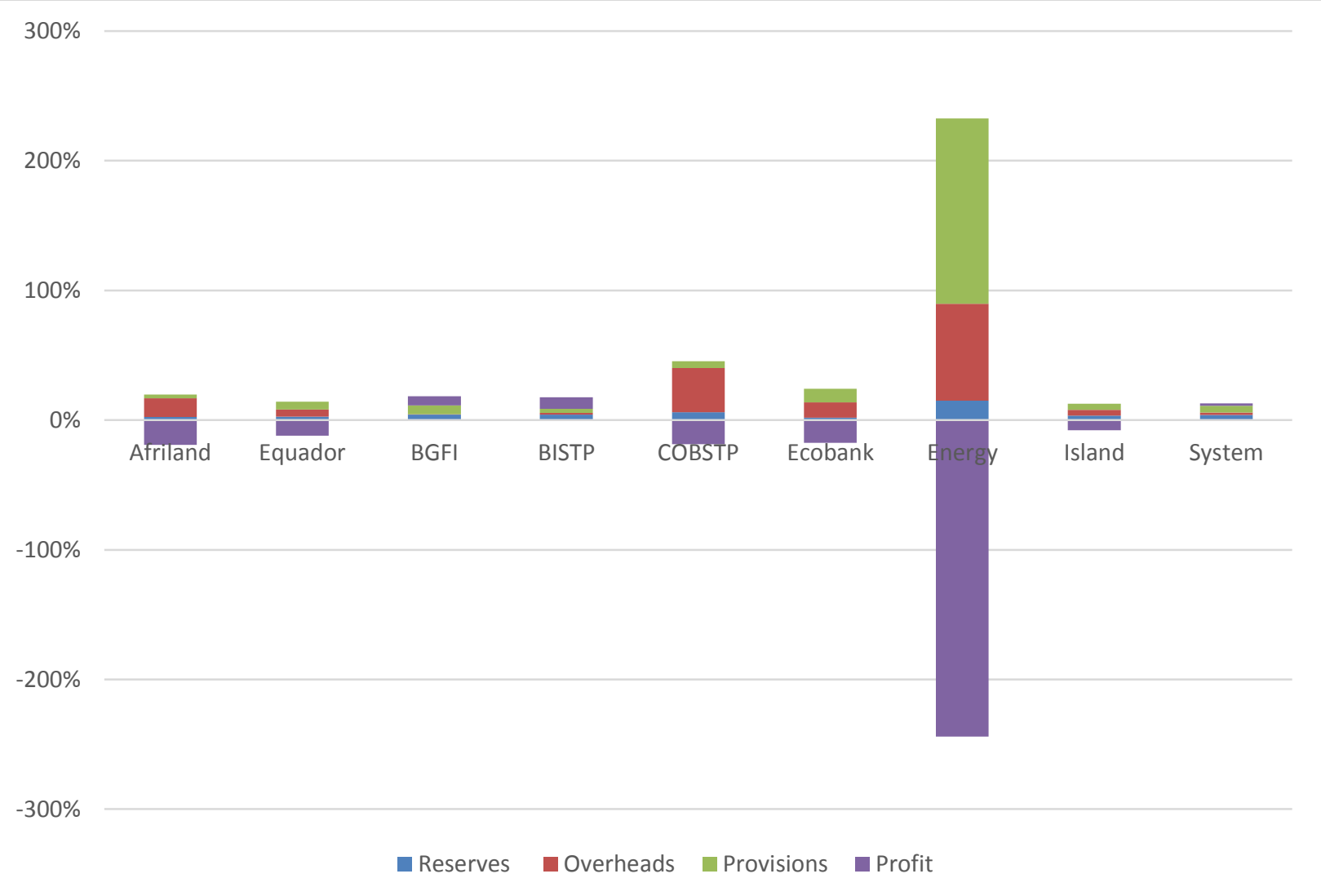

Source: BCSTP and own calculation

\section{Policy implications for small financial systems}

Small financial systems face a number of challenges. As summarized in more detail by Bossone, Honohan and Long (2002), openness can help address some of the challenges but at the same time also increases other risks, including contagion. Openness for countries with small financial systems can take different forms and include foreign-owned financial institutions, shared or imported financial infrastructure, and open capital accounts: 
Foreign-owned financial institution. Opening the financial sector to foreign-owned financial institutions can lower the cost of financial intermediation in small financial systems by making the financial system more competitive and efficient by importing knowledge, risk-management skills, governance, access to capital and economies of scale. However, the presence of foreign banks can also raise questions in terms of foreign-owned banks crowding out the market instead of introducing competition, increasing contagion risk, and overwhelming domestic supervisory capacity.

The presence of foreign-owned financial institutions can also help small financial systems address weak domestic regulatory and supervisory capacity by outsourcing these functions, at least in part, to the home regulator and supervisor of the foreign-owned institution. However, this comes at the cost of relinquishing some control and requires trust in the capacity of the home country regulator and supervisor. Moreover, given that the operations of foreign financial institutions in small financial systems are likely not of systematic importance to the home countries of these institutions, conflicts of interest may arise. ${ }^{38}$

Shared or imported financial infrastructure. Sharing or importing financial infrastructure has the potential to significantly reduce per unit costs of some financial infrastructure components, including regulation, supervision, payments and settlement systems, and credit registries. Financial infrastructure can be shared through regional integration of financial systems or by importing financial infrastructure components from countries with larger financial systems. This comes at the expense of dependence on the external provision of these services. It is also worth noting that regional integration comes with its own set of challenges, especially if such integration is among countries with different legal and regulatory systems and policy preferences. $^{39}$

Open capital account. Access to international capital markets can provide financing for large and lumpy projects that might otherwise been not possible or too risky. However, this also increases the risk for contagion and may lead to a decrease in size of the domestic financial system overall.

The appropriate type and level of openness for small financial systems of course depends on the exact challenges faced.

Advances in technology and related innovations in business models might also help small financial systems overcome some of the challenges they face. Innovations in automation and innovations such as mobile money and agent banking make it more cost-efficient to deliver financial services not only to existing customers but also to segments of the population that could previously not be served on a sustainable basis. At the same time, advances in technology and automation may exacerbate economies of scale: while they may lead to significant cost savings, they may also require high upfront investment costs.

\footnotetext{
38 See also Beck et al. (2014) for an overview of the benefits and challenges of cross-border banking.

${ }^{39}$ See also Beck et al. (2014).
} 


\section{References}

Barajas, Adolfo, Thorsten Beck, Era Dabla-Norris, and Seyed Reza Yousefi. 2013. "Too Cold, Too Hot, Or Just Right? Assessing Financial Sector Development Across the Globe." IMF Working Paper 13/81.

Beck, Thorsten and Augusto de la Torre. 2007. "The Basic Analytics of Access to Financial Service." Financial Markets, Institution and Instruments, 17, 79-117.

Beck, Thorsten and Eric Feyen. 2013. "Benchmarking Financial Systems: Introducing the Financial Possibility Frontier." Policy Research Working Paper 6615, World Bank.

Beck, Thorsten, Michael Fuchs, Dorothe Singer, and Makaio Witte. 2014. Making Cross-Border Banking Work for Africa. World Bank and GIZ.

Bossone, Biagio, Patrick Honohan, and Millard Long. 2002. "Policy for Small Financial Systems." In Gerard Caprio, Patrick Honohan, Dimitri Vittas (eds.) Financial Sector Policies for Developing Countries: A Reader, Washington, DC: World Bank.

Claessens, Stijn and Neeltje van Horen. 2014. "Foreign Banks: Trends and Impact." Journal of Money, Credit, and Banking, 36(3), pp.295-326.

IMF. 2015. "Democratic Republic of Sao Tome and Principe." IMF Country Report 15/196. 


\section{Annex 6: Credit Registry Gap Analysis Chart}

\begin{tabular}{|c|c|c|c|c|c|c|c|c|}
\hline \multirow{2}{*}{ Area } & \multirow{2}{*}{ Gap \# } & \multirow{2}{*}{ Gap description } & \multirow{2}{*}{$\begin{array}{l}\text { Current } \\
\text { Criticality }\end{array}$} & \multirow{2}{*}{$\begin{array}{c}\text { Suggested } \\
\text { Priority }\end{array}$} & \multicolumn{4}{|c|}{ Risk related solution timeframe perspective } \\
\hline & & & & & A5AP & Nearterm & Mid term & Long term \\
\hline $\begin{array}{l}\text { System } \\
\text { architecture }\end{array}$ & 1 & Cisco router without back up & & 1 & & & & \\
\hline $\begin{array}{l}\text { Systern } \\
\text { architesture }\end{array}$ & 2 & $\begin{array}{l}\text { Absence of IT recovery infrastructure } \\
\text { (D/R) }\end{array}$ & & 1 & & & & \\
\hline $\begin{array}{l}\text { System } \\
\text { arechitecture }\end{array}$ & 3 & $\begin{array}{l}\text { Insufficient storage capacity for } \\
\text { backups: }\end{array}$ & & 1 & & & & \\
\hline $\begin{array}{l}\text { 5istem } \\
\text { archinecture }\end{array}$ & 4 & Deficiencies on physikal security & & 2 & & & & \\
\hline If Governance & 5 & improving backug management & & 3 & & & & \\
\hline IT Governance & 6 & $\begin{array}{l}\text { Disaster/Recowery plan } \\
\text { (Disaster/Recovery management) }\end{array}$ & & 3 & & & & \\
\hline $\begin{array}{l}\text { System } \\
\text { architecture. }\end{array}$ & 7 & IT Team bptops are becoming obsolete & & 1 & & & & \\
\hline $\begin{array}{l}\text { System } \\
\text { architecture }\end{array}$ & 8 & $\begin{array}{l}\text { Intrusion protection forotection } \\
\text { unauthorized access fram outside } \\
\text { (firewail) is currently done by a } \\
\text { software) }\end{array}$ & & 2 & & & & \\
\hline IT Governaace & 9 & Absence of Help Desk & & 4 & & & & \\
\hline IT Governance & 10 & $\begin{array}{l}\text { Ahsence of an incident Management } \\
\text { procens }\end{array}$ & & 4 & & & & \\
\hline iT Governance & 11 & $\begin{array}{l}\text { Impravable configuration management } \\
\text { (configuration management is not } \\
\text { appropriatoly organized) }\end{array}$ & & 3 & & & & \\
\hline IT Governance & 12 & Improvable logical security & & 4 & & & & \\
\hline
\end{tabular}




\section{Annex 7: Evaluation of Current Legal Framework in STP}

Enhancing the legal and regulatory framework in the financial sector is needed to better define the scope of activities for different financial institutions and to regulate those which are currently unregulated (i.e., insurance, microfinance/financial cooperatives and pensions). The Central Bank has already elaborated a preliminary new draft of the FIL and is working on a number of other draft laws and regulations, and will soon start a full revision of existing Normas de Aplicação Permanente (NAPs). In particular, in addition to a new draft of the FIL (see below), the Central Bank is working on a separate law on microfinance, as well as on draft regulations on microcredit, pension funds, pension funds for Central Bank staff, and the establishment of a Commission for Pension Funds for CB employees.

Decrees are in the process of being drafted, on agency insurance, compulsory automobile insurance and insurance contracts. Once this package of measures is adopted, the country will have a more comprehensive regulation of financial sector. Since these drafts, although each at a different level of development, are still at an early stage, and taken jointly will undertake a full reform of the financial markets, it is recommended that this exercise is done in the light of a general strategy on development of the sector and having in mind also the need to foster the country's financial infrastructure.

The draft FIL roughly mirrors Portuguese legislation. However, it departs from it in particular as for categories of activities included within one of the three mentioned categories.

First, it is difficult to exactly distinguish which entities/activities would follow under the category of "credit institutions" as opposed to "financial institutions", since a number of activities seem to overlap (as for instance in the area of investment activities, or of payments) or are defined very generically.

In the second place, although it is understood that credit institutions are gathered under the same category because of their credit activities, these are not necessarily their main activities under current article 4 of the draft law: this produces the effect that when capital and other prudential requirements need to be identified for credit institutions at large, it becomes very difficult to exactly define relevant parameters.

Finally, although it is correct that in the past Portugal had followed the model of distinguishing between credit institutions at large and financial institutions, the law was amended in 2014 to limit the scope of credit institutions to basically deposit-taking. This amendment was due to the new EU measures adopted in 2013 to better articulate prudential requirements in the financial sector according to international standards. ${ }^{40}$ As a consequence, the change made in Portugal

\footnotetext{
40 Decreto-Lei n.o 157/2014 (24/10/2014): “Embora não se introduza qualquer alteração na definição de "instituição de
} crédito", que consta do Regulamento (UE) n.․ 575/2013, nos mesmos termos em que constava da Diretiva n. 9 2006/48/CE, 
could be taken into consideration to evaluate on what basis categories of institutions in the financial markets should be separately taken into consideration.

According to the Law on Financial Institution, the central bank must submit to the Court a request to declare the bankruptcy of a bank and suggest the receiver to be appointed. No specific law regulates the liquidation of a bank and; consequently, the process must comply with the commercial law. The central bank will have to work closely to the Court to set all procedures for the bank's liquidation, especially, the notice and registration of the bankruptcy, powers and duties of the receiver, the priorities in payment of claims and the receiver compensation policy, among other issues.

The draft microfinance law should clarify whether micro-credit as such deserves a special treatment as being mentioned in both draft laws. If the provision of micro-credit is also covered under the FIL it must balance consistency in approaches to avoid regulatory arbitrage while at the same time ensuring proportionality for smaller institutions. In addition, criteria shall be clearly defined to distinguish entities providing financial services at a small scale ("microservices") from those providing the same kind of services to the general public. Finally, it shall be evaluated how these entities be allowed to participate into the financial infrastructure of the country. For instance, in the light of the financial inclusion strategy of the country, it shall be considered to what extent these entities can provide payment services to their clients, ${ }^{41}$ or become agents for credit institutions as for certain services.

There are several significant weaknesses in the legal framework with respect to prioritization of competing security interests in the assets of debtors.

- While the general rule that priority follows the sequence of registration of the security agreements is applicable, ${ }^{42}$ it is difficult in practice to rely on the rule because of the significant defects in the registration regime, as described in the following section on registration.

\footnotetext{
a necessidade de assegurar uma aplicação mais harmonizada no plano europeu desta definição e da nova regulamentação prudencial justificou que se introduzisse tal ajustamento. Com efeito, até à data, os Estados-Membros adotaram diferentes interpretações do conceito de "instituição de crédito", podendo distinguir-se entre aqueles que optaram por uma interpretação mais abrangente de modo a incluir neste conceito um vasto conjunto de entidades habilitadas a captar recursos provenientes do público - seja através de depósitos, seja por meio da emissão de obrigações ou de outros instrumentos equiparáveis -, e aqueles Estados-Membros que restringiram o conceito de «instituição de crédito» apenas às entidades habilitadas a captar depósitos do público. Procede-se, por isso, à redução do elenco de entidades consideradas como "instituição de crédito" mediante, por um lado, a extinção de atuais tipologias de instituições de crédito que deixaram de ter atualmente acolhimento prático pelos agentes económicos e, por outro lado, a qualificação da maioria das demais como sociedades financeiras. As sociedades financeiras não ficam sujeitas, por conseguinte, a todo o acervo de normas prudenciais aplicáveis às instituições de crédito decorrentes da Diretiva n.o 2013/36/UE e do Regulamento (UE) n. o 575/2013, ficando outrossim sujeitas às normas que vierem a ser definidas pelo Banco de Portugal. Deste modo, esta alteração permite a redução para aquelas entidades dos custos de contexto criados pela regulação europeia, tornando-as mais competitivas no mercado interno."

${ }^{41}$ Digital payment instruments are one of the main issues to address in this context.

42 Interview with local lawyer.
} 
- In the absence of a comprehensive bankruptcy reform, different rules may apply to different types of debtors with respect to priority in distribution.

- The Civil Code provides for super-priority of claims for delinquent taxes, wages and salaries, and certain other claims. ${ }^{43}$ These claims have priority over all other claims against the debtor's property after the expenses of enforcement. While these claims affect existing interests in both immovable and movable collateral, they are more likely to adversely affect prior claims in movables because the value of movable collateral is generally less than the value of immovable collateral and, hence, more likely to be totally consumed by satisfaction of a preferred claim. Experience has shown that according such claims absolute priority over the claims of lenders, even if properly registered before the super-priority claim arises, causes a dramatic reduction in the willingness of lenders to rely on movable property to secure their loans, as shown in the following figure. So these provisions of the Civil Code are a significant deterrent to reliance on interests in movables. 


\section{Figure: Access to Credit is Greater when Secured Creditors Have Priority Over Later Liens}

Credit to the Private Sector as a share of GDP

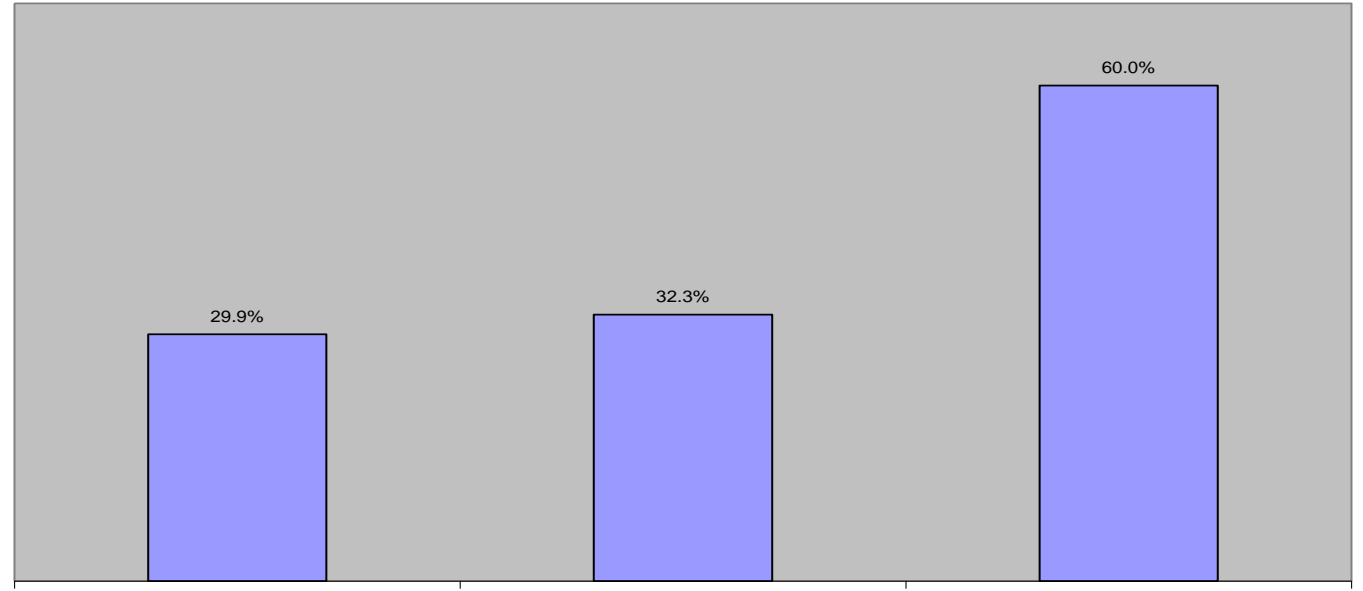

Two or more claimant groups have One claimant group has super-priority Secured creditor has absolute priority super priority

\section{Countries where:}

Source: World Bank Doing Business project database. Note: the relationship between private credit and priority status of secured creditors is statistically significant and remains significant when controlling for country size, income level, enforcement, legal origin and regions.

The existing legal framework for lending secured by movable property in São Tomé and Príncipe is outdated and in need of substantial reform. The deficiencies include the following:

- There is no single set of rules that comprehensively covers all types of assets and legal interests, so lenders must look to different rules and standards for different types of assets.

- The law requires a specific description of collateral in all cases meaning that there is no effective way to lend against inventory, receivables and other types of future property, notwithstanding that some financial institutions do take such interests as secondary security in very few cases.

- Consensual security interests have no assurance of priority, even if all possible measures are taken to assure priority, because statutorily preferred claims such as those for taxes and wages may trump a registered security interest of any type.

- For creation and registration of mortgages and pledges, it is mandatory to pay various costly fees at the Notary Registry including stamp duties, which will be passed on to the borrowers increasing the cost of accessing credit.

- By requiring registration of the agreement as a condition of effectiveness against third parties, the law introduces an element of arbitrariness and an opportunity for error into the registration process, as well as adding a burden of delivery of documents to a registry office. It also adds an implicit risk of liability for error into the registry, as in the case of an error that causes a person who searches in the registry to fail to find a registration.

- Enforcement in the event of default is made unacceptably slow and expensive by the existing law, both with respect to seizure of collateral and with respect to disposition. 


\section{Annex 8: Secured Lending in São Tomé and Principe}

The following report presents the finding of a diagnostic mission that the Finance and Markets Global Practice undertook in São Tomé and Principe on January 26-29, 2015 to conduct preliminary assessments of the existing legal and institutional frameworks for secured transactions and to meet with public and private sector stakeholders to understand the extent to which there is potential for the implementation of a movable collateral registry (schedule of meetings attached in Annex XIII).

The assessment is part of the World Bank Group's Financial Sector Development Implementation Plan (FSDIP), which aims to enable the authorities to implement key financial sector reforms in order to achieve a more efficient, sound and inclusive financial sector. The present report analyzes the current secured transactions system in Sâo Tomé and Principe. The diagnostic mission conducted aimed at identifying the needs of access to financing for local economic actors, identifying deficiencies in present legal mechanisms and current registries, and collecting any additional inputs needed to write this report as well as to propose recommendations for a potential future reform in this area.

The ultimate objective of a modern and functional secured transactions system is to provide access to credit for all economic sectors, and all types of economic actors. Secured transactions systems (the use of movable property as collateral for a loan) enable businesses and consumers to use their assets as security to generate capital. These systems are an important alternative to traditional lending because they serve borrowers with characteristics that can fall outside a bank's typical business lines and allow banks to further develop their commercial banking products. Secured transaction loans are typically secured by a company's accounts receivable, inventory, and equipment, and they primarily benefit start-ups and small and medium enterprises (SMEs) that do not have real estate or land to mortgage - from the farmer pledging his crop as collateral for an agricultural loan, to the manufacturer of consumer or industrial goods pledging his raw materials and finished products for working capital, to the seller of goods or services pledging the cash flow from its customer accounts as collateral for business expansion.

São Tomé and Príncipe (STP) has not yet been able to reap the rewards of a well-structured and modern secured transactions system, largely because (1) the legal framework is fragmented, obsolete and non-compliant with international accepted standards, based on outdated provisions in the Civil and Commercial Codes, and (2) the institutional framework, i.e. the registration system for security interest in movable assets, is dysfunctional.

A general overview of the financial sector points to: (i) too many commercial banks for such small economy with one of them dominating with $50 \%$ of the market share; (ii) very high NPLs due to lack of loan repayment culture making lending a risky activity; (iii) even when Banks have 
high liquidity they are not willing to lend and when they do is at very high interest rates; (iv) cashbased economy with a high degree of informality; ( $v$ ) inefficient judicial system and inadequate bankruptcy laws that make it very difficult for a lender to recover in the event of default.

Lending is mostly secured by real estate, which is the preferred type of collateral in São Tomé and Príncipe. According to the information provided during the interviews, movable assets are rarely taken as collateral due to the weakness and uncertainty of the legal framework and the lack of capacity of the banks to do this type of financing. In addition, the leasing and factoring industries have not been developed in the country.

The existing legal and institutional frameworks for secured transactions are incomplete. There are gaps in the scope of assets that can be used as potential collateral and in the registry system. Both the legal framework and the institutional framework (the registry system) are fragmented. There is no law on secured transactions per se in STP. The provisions relating to secured transactions are scattered in the outdated Civil Code and the Commercial Code covering both mortgages on buildings and land and pledges ("penhor") on movable property. However, these texts have not been reformed since the colonial times to adequately include modern commercial loan transactions.

The main shortcomings identified in the existing legislation include:

- Excessive complexity, burdensome requirements and considerable cost for the creation and registration of mortgages and pledges. It is mandatory to pay various costly fees at the Notary Registry including stamp duties, which will be passed on to the borrowers increasing the cost of accessing credit.

- Lack of clear priority provisions governing priority among secured and unsecured creditors. For this reason banks are reluctant to lend not knowing if their security rights will be protected vis-à-vis other creditors.

- Complex enforcement process that could take several years (from 5 to 10 years) and lack of specialization and training among judges in commercial matters make the judicial system highly unreliable. All stakeholders would welcome extra-judicial remedies to expedite these processes.

Because the deficiencies are so fundamental, piecemeal reform is unlikely to be sufficient to significantly improve the environment for lending secured by movables. Therefore, a comprehensive reform of the legal framework is needed in order to improve access to finance for businesses and consumers in STP. The proposed recommendations for reform would include:

1) Adoption of a modern standalone secured transactions law that should include provisions on five major substantive features and will abrogate any previous related provisions in the Civil Code, Commercial Code or any other law that is in conflict with the new law: 
- A broad scope that will apply to all rights in movable assets created by agreement that secure payment or other performance of an obligation, regardless of the form of the transaction, the type of the movable asset, the status of the grantor or secured creditor or the nature of the secured obligation.

- A simple process for creating an enforceable security interest by agreement of the parties

- A clear and comprehensive scheme for determining the priorities of competing interests in movable property

- A simple and effective means of publicizing interests in movables to facilitate assurance of a creditor's priority

- A quick and effective enforcement process upon default of the debtor

2) Approval of registry regulations that will implement the law by setting out the rules for operation of a movable collateral registry.

3) Alignment of Central Bank directives on eligible collateral and provisioning with the new secured transactions system in line with Basel II recommendations.

4) Design, development and establishment of an electronic centralized collateral registry for security interests on movable property. The only purpose of the notice registry would be to publicize the security interests and thereby to establish the priority of secured creditors.

5) Awareness raising and Capacity building. It will be needed to raise stakeholder awareness on the need for reform using different communication mechanisms. In addition, it will be necessary to train financial institutions, businesses and the legal community on the existence, use and operation of the new system.

\section{Role of Collateral Laws and Registries in Increasing Access to Credit}

Effective secured transactions laws and collateral registries are a crucial component of a healthy financial sector and business climate. In their absence, entrepreneurs are unable to leverage current assets into capital for investment. Modern secured transactions systems allow the use of movable assets (both tangible and intangible) such as equipment, inventory, accounts receivable, cash flows, livestock, crops and others as collateral in exchange for loans. Economic analysis also suggests that small and medium-sized businesses in countries that have stronger secured transactions laws and registries have greater access to credit, better ratings of financial system stability, lower rates of non-performing loans (Djankov, McLiesh and Shleifer, 2005), and a lower cost of credit (Lago, Lopez, Saurina 2007). In emerging market countries, for lack of appropriate secured lending regulations and collateral registries, the assets owned by most firms are a poor match for the assets that lenders accept as collateral. 


\subsection{Economic benefits of having a modern secured transactions system}

A well designed secured transactions system can help create more robust financial systems by promoting credit diversification, allowing non-bank financial institutions (NBFIs) to provide credit (thereby reducing dependence on bank credit and dominance by commercial banks), and relying less on real estate as collateral. Allowing for natural synergies in commercial lending by banks and NBFIs can provide significant advantages to production enterprises, agricultural enterprises, retailers and SMEs, by: (i) enabling financial institutions to diversify their portfolios to accept movable assets, including more liquid security (such as receivables or investment instruments); (ii) providing critical information on existing security interests in movable assets and assuring the creditor's priorities over those assets; (iii) enabling financial institutions to make more informed credit decisions on collateral lending, thereby strengthening their risk management practices; and (iv) establishing better reporting mechanisms on collateral lending practices to the supervision authority or regulator.

\section{Collateral Registries and Moveable Assets as Security}

Reforming movable collateral frameworks contributes to increasing levels of credit at decreasing costs. In countries where security interests are perfected and there is a predictable priority system for creditors in case of default, credit to gross domestic product (GDP) averages $60 \%$, compared with 30 - $32 \%$ averages for countries without a clear creditor protection system.

Experience from industrial countries shows that borrowers using collateral get nine times the level of credit, repayment periods up to 11 times longer, and interest rates $50 \%$ lower than borrowers without collateral. Recent research by the World Bank's Development Economic (DEC) group, in collaboration with the IFC Secured Transactions team, shows that the introduction of movable asset registries has a positive effect on firm financing, with:

$>$ An increase in access to finance by 8 percentage points

$>$ An increase in access to a loan by 7 percentage points

$>$ An increase in percentage of working capital financed by banks by 10 percentage points

$>$ An increase in loan terms by 6 months and a reduction in interest rates by 3 percentage points

Despite the logic of using movables as collateral, lending in many countries concentrates almost exclusively on real property, which is preferred to movable collateral because there is a legal and registry framework that supports rights in real property. Conversely, due to the weakness and uncertainty of the movable property legal framework, movable collateral and in particular working assets of an enterprise, is rarely taken as security. As a result, while secured lending is the preferred form of lending in formal credit markets, movable property valued at 
trillion of US\$ in developing countries is classified as "dead capital" because of non-existing or poorly functioning collateral laws and registries. While $78 \%$ of the capital stock of a business enterprise is typically movable assets such as machinery, equipment or receivables and only $22 \%$ immovable property (see Figure 1), financial institutions are reluctant to accept movable property as collateral. Banks heavily prefer land and real estate as collateral. One of the Solutions to Increase Access to Credit Lies in Reforming Secured Transactions Laws and Registries. Providing legal structures through which movable assets (both tangible and intangible) such as equipment, inventory, accounts receivable, vehicles, shares and stocks, intellectual property rights, livestock, etc., can be effectively used as collateral will significantly improve access to finance by those firms that need it the most.

Figure: The Collateral Gap: Assets of an Enterprise vs. Assets Required as Collateral

Assets of an Enterprise

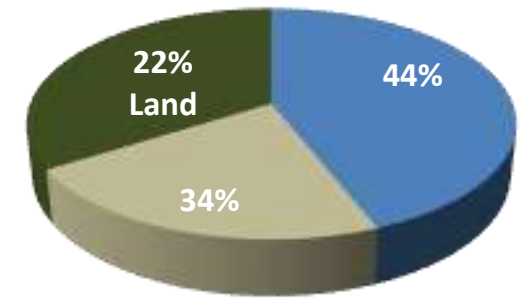

- Equipment/Inventory: $44 \%$

- Accounts Receivable: $34 \%$

Real Property: $22 \%$

\section{Assets required as Collateral}

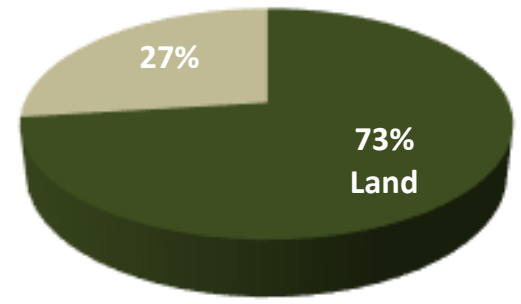

- Real Property: $73 \%$

Movable Property: 27\%

Source: World Bank Enterprise Surveys

Without the benefit of a modern secured transactions system, the banking relationship tends to be more inflexible for the debtor, and riskier for the creditor. To cover the higher risk, banks respond by lending less or by increasing the cost of credit to cover the additional uncertainties, especially as related to higher-risk borrowers (such as small firms and low-income households). Conversely, secured transactions systems based on international standards and best practices have been shown to increase the credit capital in the local economy, creating a virtuous legal/economic environment through increased legal certainty, which in turn reduces the risk of a loan, thereby reducing the cost of credit. Economic analysis in countries studied by the World Bank Group demonstrates that reforms, which increase the effectiveness of secured transactions law and registries considerably, improve a country's lending markets. Countries that score higher on the Legal Rights Index have greater access to credit, better ratings on financial system stability, lower rates of non-performing loans, and a lower cost of credit. This results not only in facilitating access to finance, but also in increasing the competitiveness of domestic economic actors.

There is strong country evidence about the impact that this type of reform can have in increasing access and improving the credit environment in a number of jurisdictions. The following table is an example of some of the results of specific reform projects implemented in several jurisdictions with the support of the IFC (World Bank Group). 
Table 1: Impact of Secured Transactions Reforms in World Bank Projects

\begin{tabular}{|c|c|c|}
\hline Region & Country & Results to Date \\
\hline $\begin{array}{l}\text { Middle } \\
\text { East and } \\
\text { North } \\
\text { Africa }\end{array}$ & Afghanistan & $\begin{array}{l}\text { - After the collateral registry launch in Feb. 2013, 3,869 notices were filed (total of } \\
\text { USD } \$ 730 \text { million as of April 2015). Since then, the number of searches has reached } \\
9,318, \text { which shows active and correct utilization of the registry data. } \\
\text { - The score in the Legal Rights Index for Afghanistan increased from } 1 \text { to } 9 \text { after the } \\
\text { reform }\end{array}$ \\
\hline \multirow[t]{3}{*}{ Asia } & China & $\begin{array}{l}\text { Building on the success of the previous secured transactions initiative (which } \\
\text { unlocked more than US\$3.5 trillion in financing); IFC continues to deepen the } \\
\text { penetration of movables lending in China. Most notably, IFC supported PBOC to } \\
\text { launch an Accounts Receivable Financing Platform, which provides an innovative } \\
\text { channel for lenders to reach SME borrowers. Within the first year of pilot launch, } \\
\text { the A/R Platform has attracted } 25,396 \text { registered users (lenders, buyers/suppliers) } \\
\text { with US\$6.7 billion of receivables loans facilitated. }\end{array}$ \\
\hline & Vietnam & $\begin{array}{l}\text { Since its official launch in March } 2012 \text {, the Vietnam secured transactions registry } \\
\text { has already recorded } 400,000 \text { registrations and facilitated US\$13.7 billion in } \\
\text { financing to over } 215,000 \text { SMEs and } 15,000 \text { micro enterprises cumulatively. }\end{array}$ \\
\hline & Uzbekistan & $\begin{array}{l}\text { On July } 12014 \text {, the Central Bank launched an internet-based collateral registry, the } \\
\text { first of such type in the Commonwealth of Independent States countries. Around } \\
150,000 \text { loans have been registered so far in the registry. }\end{array}$ \\
\hline $\begin{array}{l}\text { Latin } \\
\text { America } \\
\text { and } \\
\text { Caribbean }\end{array}$ & Colombia & $\begin{array}{l}\text { - Since the collateral registry went live in May } 2014 \text {, there have been more than } \\
885,000 \text { registrations for a total of roughly US } \$ 69 \text { billion, far exceeding IFC's original } \\
\text { target of US } \$ 1.2 \text { billion after three years, making this highly successful project a } \\
\text { model for the region. } \\
\text { - The score in the Legal Rights Index for Colombia increased from } 5 \text { to } 12 \text { after the } \\
\text { reform. Today Colombia is the first ranked country in Legal Rights Index }\end{array}$ \\
\hline \multirow[t]{2}{*}{$\begin{array}{l}\text { Sub - } \\
\text { Saharan } \\
\text { Africa }\end{array}$} & Ghana & $\begin{array}{l}\text { Since the launch of the modern registry in Jan. 2010, the registry facilitated US } \$ 14 \\
\text { billion in financing from movable and immovable assets (movable assets accounted } \\
\text { for US } \$ 3 \text { billion). As of June } 2014,15,283 \text { registrations valued at US } \$ 75 \text { million } \\
\text { were made by women entrepreneurs (women entrepreneurs accounted for } 692 \\
\text { loans valued at USD } \$ 18 \text { million). }\end{array}$ \\
\hline & Liberia & $\begin{array}{l}\text { The Liberia Collateral Registry was officially launched and became operational on } \\
\text { June } 18,2014 \text {. Despite the Ebola crisis, in the first } 6 \text { months of operation of the } \\
\text { registry, } 30 \text { lenders have registered as users and } 33 \text { loans secured with movables } \\
\text { have been registered for a value of US\$ } 226 \text { million. }\end{array}$ \\
\hline
\end{tabular}

\subsection{The need for a modern legal and regulatory secured transactions framework}

Key features of a modern secured transactions law must include:

A Broad Scope of Collateral: A secured transactions law is effective when it broadly defines the scope of permissible collateral to include tangible and intangible property of any nature, assets that do not yet exist or are owned by the debtor (future assets), and a changing pool of assets. A single, unitary concept of security interest should be adopted for granting a real right in any movable property from the debtor to the creditor in order to secure an obligation of the debtor. Finally, the system must offer the option for the collateral to be described generically to allow 
the possibility of creating security interests in future assets and fluctuating assets, a prerequisite for modern inventory and receivables financing.

Publicity of Security Interests in Movable Property: A key part of a modern secured transactions law is an efficient centralized electronic (web based) registration system based on notices and not on document registration. Unlike title (ownership) registries such as a real estate registry, a secured transactions registration registry does not create or transfer property rights. Such movable collateral registration serves two functions: (1) it notifies third parties of the existence of the security interest and (2) it establishes the priority status of a security interest based on the date of registration.

Priority Scheme: Priority of claims, such as security interests in property, determines the sequence in which competing claims to the collateral will be satisfied from the proceeds of its disposition when the debtor defaults on one or more of the claims. An effective priority system is based on two main components; (i) a clear public policy underlying each priority; and (ii) a clear set of rules regulating the order of priorities to facilitate the implementation of these public policies. The general priority rule used in modern secured transactions systems is based on notice and on the "first to register rule". There are exceptions to this rule and therefore it is important to clearly enumerate those in the law.

Enforcement of Security Interests: A modern secured transactions law will need to include provisions related to the following enforcement principles: (i) Possibility for the secured creditor to seize the secured asset in case of default without court assistance. (ii) Out of court enforcement mechanisms can include the execution through the financial institutions and other specialized institutions or through Alternative Dispute Resolution (ADR) Mechanisms, such as arbitration or mediation. (iii) Easy disposition of the asset by the secured creditor by either private sale or public auction. (iv) Debtor's protection during enforcement proceedings - While execution proceedings are designed to allow secured creditors to enforce their rights efficiently, protection of debtors' rights shall also be included to prevent abuses.

\subsection{The need for an electronic collateral registry system}

Developing a functioning collateral registry is a critical part of secured transactions reform. Not having a functioning collateral registry defies the purpose of modern secured transactions systems. A legal reform in itself will not be sufficient to maximize the benefits of secured transactions systems. The main principles that apply to modern secured transactions registries are indicated in the table below.

Features of a state of the art registry system

1. Notice based system: no documents need to be submitted and the registry is designed as a notice based system

2. Information required: limited information related to creditor, debtor, description of collateral and maximum amount of obligation 
3. Electronic, internet-based platform: both for registrations and searches functioning $24 / 7$ (except for system updates)

4. Range of services must include registrations, amendments, cancellations and searches.

5. Centralized registry: all information is available in one single database for the whole country

6. Single registry for all security interests in movables: all existing security interests can be searched through a single registry (does not matter if all the info is in one registry or if the registry has real time links to other registries)

7. Flat and reasonable fees for registrations and searches: the registry charges a reasonable flat fee (to cover the costs administering the transaction) for registrations and for searches (charging for searches is optional)

8. Registration done by creditors or their legal representatives: creditors or their representatives are responsible for registering the security interests in the registry

9. Debtors can be legal or natural persons: both individuals or businesses (any type of business) might appear as debtor in the registry

10. Unique identifiers for both creditors and debtors: a unique alphanumeric identifier is used to enter information about creditors and debtors

11. User accounts are established for regular users: creditors will be allowed to open a user account to register security interests and conduct searches

12. Searches: any person can conduct a search in the registry from any place without a need to justify the search

13. Real time data: registrations will be part of the system immediately and available for searches. Information on searches will be provided immediately after the search (in real time)

14. Security of data: security devices such as tokens or passwords will be required for users when doing registrations, amendments and cancellations

15. No verification of information by the registrar: the registrar is not allowed to verify the identity of the registrant or the information contained in the notice

16. Indexing for searches: searchers will be able to conduct searches by at least three possible indexes: debtor identifier, serial number goods and registration number

17. Type of debtor: debtor information is disaggregated by type of debtor such as individual, business (type of business), foreigner

18. Maximum amount of the obligation secured: a maximum amount of the obligation secured must be entered by the registrants when doing the registration

19. Registration of non-consensual liens: registration of non-consensual liens (like taxes, judgment liens, etc.) is required if established by law

20. Disaster recovery sites: the registry will have redundant servers in secured locations in case of system failures or disasters that affect the information contained in the registry 
21. Statistical capabilities: the registry is designed so that statistical information can be easily retrieved and produced in reports (number of registrations, searches, volume of credit, types of assets used, types of debtors, etc.)

22. Methods of payment: the registry does not accept cash payments and allows for at least two methods of payment such as pre-paid accounts, electronic transfers, and credit or debit cards.

23. Limited role of registrar: the registrar will not be allowed to modify or change any registrations. Only registrants are allowed to do changes to existing registrations

24. Claim procedure for erroneous information and liability of registry: the registry will establish the rules for claims against erroneous information contained in the registry, but will not be liable for any misleading or erroneous information entered by the registrants.

1.4. The need to create awareness among stakeholders and provide training on the functioning of the new systems.

An element of reform that is usually neglected, but that will be a critical key contributor to the success of a reform in this area. The awareness of the reform and the new system in place should be a continuous exercise during the whole implementation and following the completion of the reform. With regard to training, the target groups that should receive training on the new system include both public and private sector stakeholders: creditors, the business community, lawyers and notaries, judges, enforcement or execution officers, registry operators.

\section{Secured Transactions Framework and Practice in São Tomé and Principe}

São Tomé and Príncipe, like most countries in Sub Saharan Africa, has not yet been able to reap the rewards of a well-structured and modern secured transactions system because the legal and institutional frameworks are clearly insufficient. The legal framework is incomplete, though it does permit lending against movables in some cases. The institutional framework, i.e. the registration system, is inadequate and incomplete in many respects as well.

The following sections examine the existing lending practices related to movable collateral, as well as the current legal and institutional frameworks. That examination is followed by recommendations for modernizing these frameworks.

\section{Lending Practices in São Tomé and Principe: Financial Sector Overview}

São Tomé and Principe's financial sector is dominated by commercial banks that account for 98 percent of total assets in the system. The banking system is highly concentrated with the largest bank, Banco Internacional de São Tomé and Principe (BISTP) ${ }^{44}$ holding half of total assets and credit, and two-thirds of deposits. Seven commercial banks have 27 bank branches in five of seven districts of the country where $86 \%$ percent of the population is located. All banks (except BISTP) are predominately foreign owned from Angola, Cameroon and Nigeria primarily.

\footnotetext{
44 The Government has a 48 percent controlling share with the remaining shares held by banks from Angola and Portugal.
} 
Non-performing loans (NPLs) are high at $\mathbf{1 6 . 3}$ percent in December 2014, albeit lower than the 22.5 percent registered in 2013. Provisions increased to 17.4 percent of NPLs in 2014 relative 7.5 percent in 2013. With the exception of the largest financial institution, banks are not profitable limiting their opportunities to recapitalize from earnings. The combination of a high NPL rate, decline in capital adequacy, and absence of profitability in the banking sector increase the risks in the banking system.

Credit to the private sector is $\mathbf{2 0}$ percent below the peak registered in May 2013 and loans to assets (34 percent) are at their lowest level in over a decade. Despite a slight decline in asset impairment banks continue to decrease the amount they allocate to their credit portfolios, which increases liquidity. The absence of domestically issued securities, scarce foreign exchange, and central bank reserves that pay zero interest create a challenging operating environment for most banks. With weak prospects domestically several banks are looking outside of the country for investments and lending opportunities.

Access to finance remains one of the main constraints for private sector development. Demand side data indicates that 14.4 percent of businesses and/or adults above 15 years of age have an active loan. Following the entry of several foreign investors and banks in the mid-to late 2000s bank lending to the private sector began to increase. Access to credit continues to decline from a peak in 2011.

Non-banking finance is largely unexploited (only two local insurance companies in the market) or non-existent given the absence of capital markets. It is also limited by weak capacity and small scale. Only 4.3 percent of the adult population above 15 years of age has some form of private insurance and less than 5 percent of adults are clients of consumer finance firm (equivalent to 4,800 policyholders). Although vehicular insurance is mandatory, industry estimates suggest that only 5 percent of drivers purchase insurance. There is no interbank market and microfinance system is still nascent and not regulated.

\section{Getting Credit and Secured Transactions in São Tomé and Principe}

São Tomé and Principe does not have a specific law on Secured Transactions. Instead, the secured transactions system is characterized by a fragmented legal framework, with scattered provisions on financing secured with movable property in different parts of the legislation, included mostly in the Civil and Commercial Codes. There is not a centralized electronic registry for security interests in movable property in São Tomé and Principe. The system is based on the civil law tradition and nationwide reforms in this area have never been introduced.

São Tomé and Principe ranks 185th in the world on the Getting Credit indicator in Doing Business 2015 (see Table 2). The Getting Credit indicator has two components: the Legal Rights Index measures the protection of creditor and debtor rights in collateral and bankruptcy laws, while the Credit Information Index captures the depth and breadth of credit information. On the Legal Rights Index (see Table 3), São Tomé and Principe scores 0 out of a possible 12 points, 
indicating that creditors do not enjoy the same degree of predictability, certainty and protection that creditors in other economies do to secure loans using a variety of moveable assets. In fact, São Tomé and Principe has one of the worst scores in the world in the Legal Rights Index, with only 8 other countries in the world scoring the same.

Table: Getting Credit in São Tomé and Principe

\begin{tabular}{|c|c|c|c|c|c|c|c|}
\hline Getting Credit & & & & ails » & View methodology » & Compa & leconomies : \\
\hline DB 2015 RANK & 185 & DB 2014 RANK $^{\star * *}$ & 185 & CHAI & NGE IN RANK & & 0 \\
\hline DB 2015 DTF $^{\star \star}$ (\% POINTS) & 0.00 & DB 2014 DTF $^{\star \star}$ (\% POINTS) & 0.00 & CHAI & NGE IN DTF ${ }^{\star *}(\%$ POI & INTS) & 0.00 \\
\hline Indicator & & São Tom & & & Sub-Saharan Africa & & OECD \\
\hline Strength of legal rights index $(0-12)$ & & & 0 & & & 5 & 6 \\
\hline Depth of credit information index $(0-8)$ & & & 0 & & & 2 & 7 \\
\hline Credit registry coverage ( $\%$ of adults) & & & 0.0 & & & 4.5 & 12.1 \\
\hline Credit bureau coverage ( $\%$ of adults) & & & 0.0 & & & 5.8 & 67.0 \\
\hline
\end{tabular}

São Tomé and Príncipe is clearly lagging not only behind Sub-Saharan African countries but also most economies in the world in this area. There is plenty of room for improvement. Even though none of the countries in the SSA region score particularly well in this indicator, some countries like Ghana, Liberia, Nigeria, Malawi and Zambia have already reformed or are engaged in reform processes in their secured transactions systems.

If the Government of São Tomé and Príncipe undertakes a full-fledged reform of their secured transactions system, it will see a higher impact both on the Legal Rights Index indicator but most importantly on the current estate of business financing in the country. The Doing Business simulator tool (see Table 4) can illustrate the impact that a potential reform of the Secured Transactions System would have in São Tomé and Príncipe. 
Table 4: Strength of Legal Rights Index in São Tomé and Príncipe

\begin{tabular}{|c|c|c|}
\hline No. & Indicator & STP \\
\hline 1 & $\begin{array}{l}\text { Does an integrated or unified legal framework for secured transactions that extends to the } \\
\text { creation, publicity and enforcement of functional equivalents to security interests in movable } \\
\text { assets exist in the economy? }\end{array}$ & No \\
\hline 2 & $\begin{array}{l}\text { Does the law allow businesses to grant non-possessory security rights in single category of } \\
\text { movable assets, without requiring specific description of the collateral? }\end{array}$ & No \\
\hline 3 & $\begin{array}{l}\text { Does the law allow businesses to grant non-possessory security rights in substantially all } \\
\text { assets, without requiring specific description of the collateral? }\end{array}$ & No \\
\hline 4 & $\begin{array}{l}\text { May a security right extend to future or after-acquired assets, and may it extend } \\
\text { automatically to the products, proceeds or replacement of the original assets? }\end{array}$ & No \\
\hline 5 & $\begin{array}{l}\text { Is general description of debts permitted in collateral agreements, can all types of debts be } \\
\text { secured by parties, and can the collateral agreement include a maximum amount for which } \\
\text { the assets are encumbered? }\end{array}$ & No \\
\hline 6 & $\begin{array}{l}\text { Is a collateral registry in operation for both incorporated and non-incorporated entities, that } \\
\text { is unified geographically and by asset type, with an electronic database indexed by debtor's } \\
\text { names? }\end{array}$ & No \\
\hline 7 & $\begin{array}{l}\text { Does a notice-based collateral registry exist in which all functional equivalents can be } \\
\text { registered? }\end{array}$ & No \\
\hline 8 & $\begin{array}{l}\text { Does a modern collateral registry exist in which registration, amendments, cancellations and } \\
\text { searches can be performed online by any interested third party? }\end{array}$ & No \\
\hline 9 & $\begin{array}{l}\text { Are secured creditors paid first (i.e. before tax and employee claims), when a debtor defaults } \\
\text { outside an insolvency procedure? }\end{array}$ & No \\
\hline 10 & $\begin{array}{l}\text { Are secured creditors paid first (i.e. before tax and employee claims), when a business is } \\
\text { liquidated? }\end{array}$ & No \\
\hline 11 & $\begin{array}{l}\text { Are secured creditors either not subject to an automatic stay on enforcement when a debtor } \\
\text { enters a court-supervised reorganization procedure? Does the law protect secured creditors' } \\
\text { rights by providing clear grounds for relief from the stay and/or sets a time limit for it? }\end{array}$ & No \\
\hline \multirow[t]{2}{*}{12} & $\begin{array}{l}\text { Does the law allow parties to agree on out of court enforcement at the time a security interest } \\
\text { is created? Does the law allow the secured creditor to sell the collateral through public } \\
\text { auction and private tender, as well as, for the secured creditor to keep the asset in } \\
\text { satisfaction of the debt? }\end{array}$ & No \\
\hline & Total number of yes responses & 0 \\
\hline
\end{tabular}

Table 5: Reform Simulator for São Tomé and Príncipe: Legal Rights Index

\begin{tabular}{|l|l|l|}
\hline $\begin{array}{l}\text { Possible Evolution of Legal Rights Index } \\
\text { after Reform }\end{array}$ & Overall DB Rating & Getting Credit Ranking \\
\hline Current situation (0) & 153 & 185 \\
\hline Improve registry only (3) & 148 & 165 \\
\hline Improve law only (8) & 142 & 116 \\
\hline Improve both law and registry (12) & 128 & 52 \\
\hline
\end{tabular}

Source: Doing business 2015, World Bank Group

As illustrated by the graph below, São Tomé and Príncipe could significantly improve its overall position in the DB ranking as well as of course in the Getting Credit indicator, going from $185^{\text {th }}$ to $52^{\text {nd }}$ worldwide if the full reform is implemented. The World Bank Group strongly 
recommends undertaking both a legal and registry reform, not only to achieve the intended improvement in the DB ranking but also to be able to reap the rewards of increased access to credit for the business community in São Tomé and Príncipe. A legal reform only would improve the ranking but would have no impact on the ground in terms of improving access to credit, since those results would only materialized when there is a functioning movable collateral registry and the secured transactions law has been implemented.

Figure: Evolution of Sao Tome's Ranking in Getting Credit and Overall DB Rating if Secured Transactions Reform is Implemented

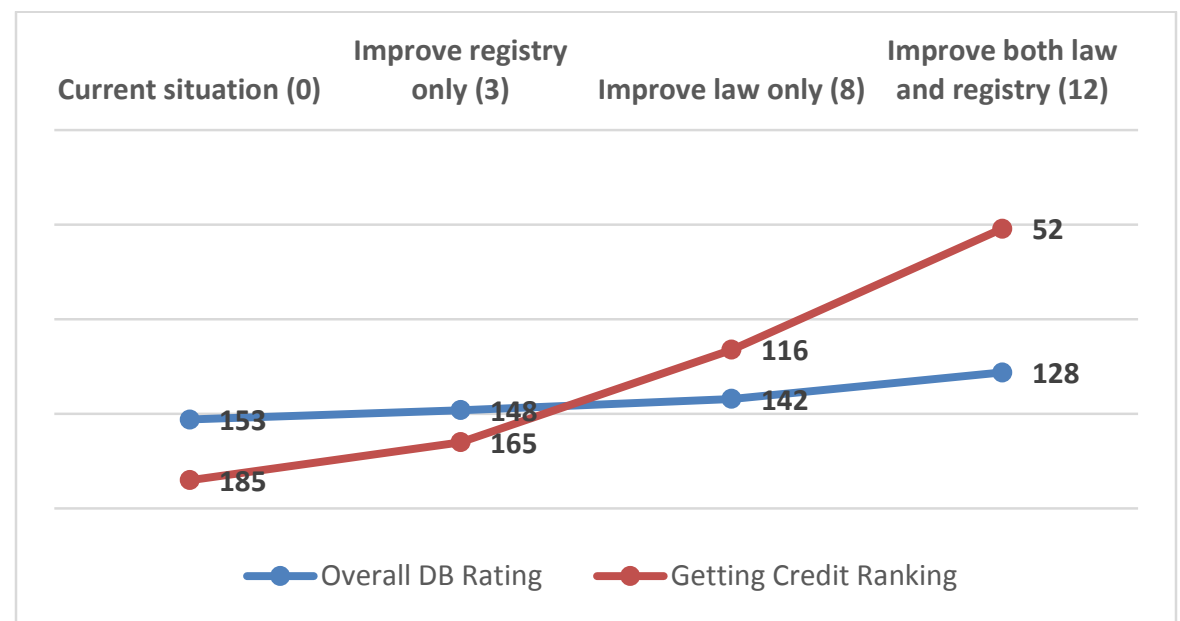

Source: Doing business, World Bank Group

\section{Collateralized Lending and Types of Assets Preferred as Collateral}

Financial institutions stated that they consider both movable and immovable property risky when securing credit but that in general they prefer immovable property as collateral. ${ }^{45}$ The value of immovable property is more stable and easier to establish that those for movable assets. In addition, they see various inherent problems with movable property, including its quick depreciation, difficult re-possession and final sale of the collateral in such a small market.

Future assets and proceeds are typically not considered part of the security interest. The current legal framework does not regulate the possible use of any future assets as security interests. However, in countries where there is a modern collateral registry, movable assets with frequent turnover like inventory, farm products and accounts receivable are sold and collected regularly, changing their nature into cash and bank deposits that are then eventually used to acquire new inventory, farm products and accounts receivable. If the law does not extend the lender's security interest to such future assets and proceeds, lenders are forced to execute new security agreements or modify existing ones, the cost of which is eventually borne by the borrowers.

\footnotetext{
45 Interviews with commercial banks.
} 
The average interest rate for loans secured by movable assets is high at $\mathbf{1 8 . 4 5 \%}$ based on the surveys. However, for immovable assets is at $15.5 \%$ showing that most banks consider the use of movable property as collateral riskier than using immovable. For the unsecured loans the average interest rate is around $26 \%$.

The most common forms of security in movable assets are: (1) purchase money for vehicles, (2) interests in account receivables and (3) pledges on machinery and equipment. However, based on the volumes these types of security are not very common. In addition, for vehicles there is a pre-requisite of transferring the title and the car's insurance to the name of the commercial bank before obtaining a loan.

The strong preference of lenders for security in real estate restricts access of the critical MSME sector to finance. MSMEs in most cases do not have unencumbered real estate that can be mortgaged, so lenders will either not lend or will lend only on unfavorable terms and in amounts that are inadequate. ${ }^{46}$

\section{MSME lending}

"Lei de enquadramento empresarial" (Lei № 11/2005) provides a classification of a firm's size by the number of employees and maximum annual income (see table 7). However, during the interviews none of the stakeholders seems to be aware of the existence of this definition, what means that in practice it is not being applied. In addition, the banks do not have data disaggregated by firm size and according to the chamber of commerce all the firms in São Tomé and Principe are micro given the very small size of the country.

Table: Firm size definition

\begin{tabular}{|l|c|c|}
\hline Firm size & $\begin{array}{c}\text { Number of } \\
\text { employees }\end{array}$ & $\begin{array}{c}\text { Maximum } \\
\text { Annual income } \\
\text { (million dobras) }\end{array}$ \\
\hline Micro & $1-3$ & 90 \\
\hline Small & $3-12$ & $90-900$ \\
\hline Medium & $12-30$ & $900-2,250$ \\
\hline Large & $>30$ & $>2,250$ \\
\hline
\end{tabular}

Source: Lei enquadramento empresarial, STP

Data on number of MSMEs and access to finance in São Tomé and Príncipe does not exist. It would be necessary to conduct a World Bank Enterprise Survey analysis in the country to obtain rigorous data. However, with the aim of providing estimations and an approximate picture of the financing gap for MSMEs in developing economies, IFC has developed and made publicly available the IFC Enterprise Finance Gap Database. In the case of São Tomé and Príncipe, because data is not available, it was necessary to extrapolate using regional averages. Therefore,

\footnotetext{
46 Interview with commercial banks.
} 
according to these estimations, there are 9,602 MSMEs in the country, which play an essential role in national employment and macroeconomic indicators. Notably, even though nearly 45 percent of MSMEs have checking accounts, only $7 \%$ percent have a bank loan. Competitiveness and economic growth requires that local businesses (particularly MSMEs) have access to the credit they need to finance their economic activities. Despite the absolute dominance of MSMEs in the private sector (in terms of numbers), their access to finance is limited. They lack physical assets of the types that financial institutions will accept as collateral. MSMEs are therefore often relegated to using informal sources of financing in many circumstances.

Notably, even though nearly 45 percent of SMEs have checking accounts, only $\mathbf{7 \%}$ percent have a bank loan. Furthermore, 43 percent of MSMEs are not served, 5 percent are underserved (with only 2 percent well served). Access to finance is the most significant concern that faces MSMEs in São Tomé and Principe, with 49 percent of all firms citing the lack of access to finance top obstacle to their local growth and competiveness (as shown in Table 7). In conclusion, these figures translate into a financing gap in the country of approximately US\$ 47 million.

\section{Analysis of Legal Framework: Existing Legal Framework}

\section{General:}

The current legal framework of São Tomé and Principe is based on laws that were inherited from Portugal and that do not adequately address the use of credit secured with movables. The laws related to lending secured with movables, are outdated and have never been modernized to correspond with financing tools that are available today in many jurisdictions around the world

Currently, there is no specific legal framework that regulates movables financing where movable assets are taken as collateral. Therefore, financial institutions in São Tomé and Principe rely on general laws-mainly the Civil Code and Commercial Code-for performing their daily secured credit transactions. The most popular secured lending instruments in Sao Tomé e Príncipe are mortgages and simple pledges, mainly on vehicles. When other types of movable assets are used as collateral these loans are unperfected because they are not publicized via registration against third parties, therefore lenders may lose their priority in case of default. In addition, the industries of leasing and factoring have not been developed yet.

The Civil Code regulates the pledge ("penhor") and the mortgage ("hipoteca"). According to the Civil Code, a pledge grants the creditor the right to obtain payment from the value of a movable asset or from any asset that cannot be subjected to mortgage belonging to the debtor or a third party with preference over other creditors. The pledge is only effective when the debtor transfers possession of the encumbered asset or of the property title to the creditor. ${ }^{47}$

\section{Creation of security interest:}

\footnotetext{
${ }^{47}$ See Article 666 and subsequent Articles of the Civil Code.
} 
As in many countries with civil law tradition, in São Tomé and Principe many acts or contracts require the intervention of a public notary to be valid in certain cases and in others to gain effectiveness as to third parties. According to the laws in São Tomé and Principe, some commercial transactions require the form of a notarial deed, which means that the act was performed by the notary public. Other acts require authenticity by the notary, which means that the notary has revised and validates the document prepared by the parties; and other acts require the sole recognition of the parties' signatures by the notary. Likewise, acts required to be registered need to be notarized first to be accepted by the registries.

Article 669 of the Civil Code states that a pledge is constituted after the asset or the property tittle is transferred to the creditor. To complete a pledge by a transfer of ownership, the creditor becomes a joint owner (or sometimes the only owner) of the asset. This mechanism is different to the regime for a non-possessory pledge where the debtor remains the owner and retains possession. According to best practice, the borrower should continue being the owner and using the asset for commercial purposes to be able to repay the loan.

\section{Priority issues:}

There are several significant weaknesses in the legal framework with respect to the priority scheme of competing security interests in the assets of debtors.

While the general rule is that priority follows the sequence of registration of the security agreements, ${ }^{48}$ it is difficult in practice to rely on the rule because of the significant defects in the registration regime (i.e. searches cannot be conducted in real time), as described in the following section on registration. These deficiencies contribute to lenders being reluctant to increase lending secured with movables.

In the absence of a comprehensive bankruptcy reform, different rules may apply to different types of debtors with respect to priority in distribution of the asset upon default.

The Civil Code provides for super-priority of claims for unpaid taxes, wages and salaries, and certain other claims. ${ }^{49}$ These claims have priority over all other claims against the debtor's property after the expenses of enforcement have been paid. While these claims affect existing interests in both immovables and movables, they are more likely to adversely affect prior claims in movables because the value of movable collateral is generally less than the value of immovable collateral and, hence, more likely to be totally consumed by the satisfaction of a preferred claim. Experience has shown that granting such claims absolute priority over the claims of lenders, even if properly registered before the super-priority claim arises, causes a dramatic reduction in the willingness of lenders to rely on movable property to secure their loans, as shown in the following figure. Therefore, these provisions of the Civil Code are a significant deterrent to reliance on interests in movables.

\footnotetext{
48 Interview with local lawyer.

49 Ibid
} 
Democratic Republic of São Tomé and Príncipe: Financial Sector Development Implementation Plan: 2017-2019 
Figure 2: Access to Credit is Greater when Secured Creditors Have Priority Over Later Liens

Credit to the Private Sector as a share of GDP

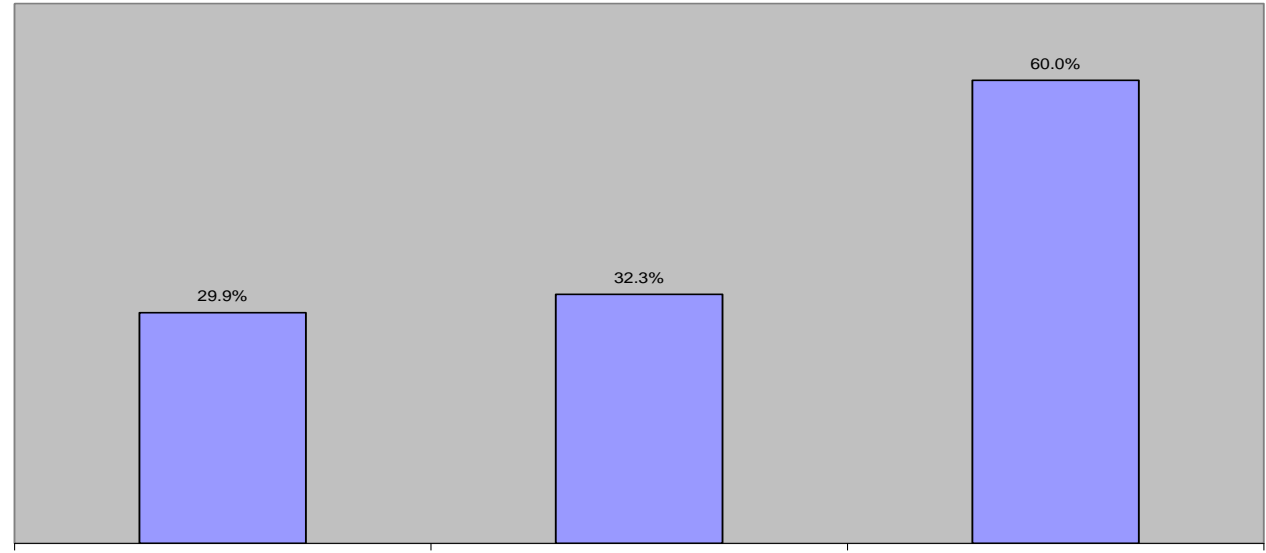

Two or more claimant groups have One claimant group has super-priority Secured creditor has absolute priority super priority

Countries where:

Source: World Bank Doing Business project database. Note: the relationship between private credit and priority status of secured creditors is statistically significant and remains significant when controlling for country size, income level, enforcement, legal origin and regions.

All institutions interviewed during the mission reported that existing registries are inefficient, expensive, and unreliable and the fee schedule is difficult to understand. The General Direction for Registries and Notaries (Cartorio), which depends on the Ministry of Justice, oversees the land registry (Registo Predial), property registry (Registo de Propiedade) and the vehicles registry (Registo Automóvel) among others. Mortgages (hipotecas) are registered at the property registry and pledges on vehicles (penhor) at the vehicles registry. However, if a creditor wants to pledge an asset other than a car it is not clear where it should be registered but it seems it should be at the property registry. In any case, there is not a practice on the registration of other types of movable assets.

Existing registries of São Tomé and Principe are currently paper based and are operated manually (although there is an upcoming project to digitalize it). Registrations of titles, mortgages, pledges and searches are also manual and the officers must consult the existing paper books. Therefore, registering and consulting takes a long time and overall, current processes are cumbersome and not efficient.

\section{Enforcement:}

Most stakeholders highlighted that lack of specialization and training in commercial law among judges make the judicial system highly unreliable in resolving commercial matters. All financial institutions stated that the enforcement procedures are a major problem that impedes their ability to rely on collateral to secure credit. Further complicating the process is the significant lack of transparency in the judicial process. The result is excessive cost and delays that prevent recovery of possession while the collateral still has its full value. The second major problem is in 
disposition of the collateral after possession is recovered as the secondary market is practically non-existent for most assets. ${ }^{50}$

Repossession of movable collateral is in fact very difficult and expensive. According to the stakeholders that were interviewed, in practice enforcement procedures generally take from 510 years, with some institutions reporting out of court enforcement in exceptional cases. Some institutions have developed mechanisms (i.e. including out of court enforcement clauses for movable collateral in their credit agreements) based on article 675 of the Civil Code that allows them to seize collateral without judicial intervention. However, these processes are not commonly used since the creditor and the debtor must agree on all terms of execution or otherwise must follow the lengthy judicial procedure.

\section{Analysis of Legal Framework: Evaluation of Current Framework}

The existing legal framework for lending secured by movable property in São Tomé and Príncipe is outdated and in need of substantial reform. The deficiencies include the following:

There is no single set of rules that comprehensively covers security interests in all types of assets, so lenders must look to different rules and standards for different types of assets.

The law requires a specific description of collateral in all cases meaning that there is no effective way to lend against inventory, receivables and other types of future property, notwithstanding that some financial institutions do take such interests as secondary security in very few cases. Consensual security interests have no assurance of priority, even if all possible measures are taken to assure priority, because statutorily preferred claims such as those for taxes and wages may trump a registered security interest of any type.

For creation and registration of mortgages and pledges, it is mandatory to pay various costly fees at the Notary Registry including stamp duties. Although there is no clarity on the costs associated to the notarization process, it will presumably be passed on to the borrowers increasing the cost of accessing credit.

The fact that the security agreement must be registered to make it effective against third parties introduces a burden of physically delivering paper documents to an office. It can also cause human errors since the information is entered manually and the registry can be liable for it. Enforcement in the event of default is made unacceptably slow and expensive by the existing law, both with respect to seizure of collateral and with respect to disposition.

\section{Recommendations}

$\underline{\text { Unify all forms of security in movables and adopt best practice legal framework for secured }}$ transactions.

\footnotetext{
50 Interview with different stakeholders, including some of the banks and bar association.
} 
The existing legal framework should be replaced by a comprehensive and integrated framework that treats all types of non-possessory interests in movables of all types of debtors on equal terms. That is, there should be no hidden interests in movables that could defeat a secured creditor's interest in movable collateral. With respect to priority and publicity, the interests in movables covered by the new framework should include, in addition to interests that secure obligations, other interests such as long-term operating leases, finance leases and the interest of a buyer of accounts receivable and secured sales contracts, in order to protect subsequent secured creditors and buyers from undisclosed senior interests. It may also be necessary for the new legal framework to be aligned and coordinated with other sets of law such as: (a) the laws governing immovable assets; (b) laws governing statutory interests such as taxes and wages to assure that priorities are preserved and consistent between laws; and (c) laws governing bankruptcy and insolvency.

Modern laws provide for a single unified security interest in movable property that subsumes all of the traditional legal security devices such as the pledge, retention of title and others. A modern secured transactions legislation generally has four major substantive features, as follows:

A simple process for creating an enforceable security interest by agreement of the parties.

A security interest is created by an agreement between the secured creditor and the debtor. The security interest so created is a generic property right that secures an obligation, and it subsumes all of the traditional forms of security in movable property, e.g. pledge, sale with retained title and others. It eliminates distinctions between types of security interests. While the property used as security may include future assets or a floating pool of assets, there is one set of rules for all such interests; i.e. rights secured by a floating pool of assets are treated on the same basis as rights secured by a fixed asset.

The agreement identifies the property that secures an obligation of the debtor to the secured creditor, and provides for enforcement against the property in the event that the debtor defaults on the obligation. The agreement creates all the rights between the parties, and is not dependent for its effectiveness on registration of either the agreement or a notice of the agreement in a registry.

The security agreement is one of three elements necessary for the security interest to attach to the collateral so as to become enforceable. The agreement may exist before the property exists and before the secured creditor has given any value to the debtor. But until the property exists in some form and the secured creditor has given value, the secured creditor has no right or ability to enforce the agreement. Therefore, the interest attaches only when there is a security agreement, the property exists and value has been given.

A clear and comprehensive schema for determining the priorities of competing interests in movable property. 
A secured creditor must be confident of the priority of its security interest in the collateral if it is to lend at a reasonable rate. Therefore, the system of prioritizing interests in movable property must be comprehensive in its coverage of all types of interests, predictable in how it operates and transparent to all users.

In modern secured transactions practice, both true security interests and certain interests of nonpossessory owners are subject to priority ranking. Thus it does not matter whether an interest is a pledge, a finance lease, a long-term operating lease, a sale of accounts or any other similar interest. That is, all interests in movables that would otherwise be hidden from a subsequent potential secured creditor must be publicized to protect subsequent secured creditors from undisclosed prior interests. All are subject to priority determination. For purposes of discussion of priority, publicity and enforcement, all will hereinafter be referred to as security interests.

Certainty of priority is provided by having one firm set of rules by which any person can determine priority at the time of creation of the security interest. In modern secured transactions practice, the concept of perfection of the security interest is used. Perfection occurs when the security interest attaches and one of three other conditions exists. Those conditions are: (1) Perfection is automatic by operation of law, as in the case of security interests in consumer goods, proceeds or other classes defined by law; (2) Perfection is by possession or control by the secured creditor or its agent, as in the case of instruments, documents, cash, deposit accounts or goods; and (3) Perfection is by registering a notice of the security interest in the registry. Priority is determined by the first to occur of (a) perfection of the interest or (b) registration of a notice in the registry, whether or not the interest has attached; that is, priority can pre-date perfection when perfection is by registration in the registry.

Transparency in priority determination refers to the ease of determination of the existence of a perfected interest or registered notice. In the case of notices registered in the registry, the secured creditor can search the records of the registry to determine if there are any effective notices of security interest in the collateral. In some jurisdictions, the notice is considered effective at the moment of delivery to the registry, but that does not provide full transparency if there is a delay between the time of delivery to the registry and the time when the notice can be found in a search of the records. The better practice is to make the notice effective to perfect the interest when the notice becomes discoverable to a person who searches the records.

A simple and effective means of publicizing interests in movables to facilitate assurance of a creditor's priority.

The registry is an essential element of an effective secured transactions regime. The registry has two purposes, as follow: (1) To provide notice to potential secured creditors of prior security interests in movable property possessed by the debtor, and (2) To permit a secured creditor to establish the priority of its security interest in movable property of a debtor.

A quick and effective enforcement process upon default of the debtor. 
Modern secured transactions laws provide for quick and simple enforcement of the secured creditor's rights in the event of a default by the debtor. Enforcement generally consists of obtaining possession and disposition of the collateral in some manner to realize its value.

Possession is obtained in different ways for different types of collateral. If the collateral is accounts receivable or other rights to payment, the secured creditor may notify the account debtors to make payment to the secured creditor. If the collateral is a deposit account, the bank or controlling secured creditor may apply the account balance to the debt it secures. In the common case of goods of any type, the security agreement may provide for return of the collateral to the secured creditor upon default, or if such a term is not included, the secured creditor may take possession or control of the collateral if it can be done without a breach of the peace. If the collateral cannot be peaceably repossessed or controlled, the secured creditor may make use of an expedited judicial procedure for repossession that is limited to the issues of existence of a security agreement covering the collateral and the breach of the agreement.

Disposition of the collateral by the secured creditor requires that notice be given to the debtor and any other secured creditor before the disposition. The debtor should have the right to redeem the collateral by paying the obligation in full, plus the expenses the secured creditor has incurred in its action to recover the property and give notice. If the collateral is not redeemed, the secured creditor may sell, lease or license the collateral in a commercially reasonable manner, or may agree with the debtor for the secured creditor to retain possession of the collateral in full or partial satisfaction of the underlying debt. If the collateral is sold, the order of distribution of the proceeds is, in sequence, to the costs of enforcement, obligations that are senior to the secured creditor's debt, the debt owed to the secured creditor, debts of other secured creditors in order of priority and, if there is a remaining balance, the debtor. If the proceeds are insufficient to cover the costs of enforcement and the debt of the secured creditor, the debtor is liable to the secured creditor for the deficiency unless otherwise agreed.

Provide the legal framework for a best practice movable collateral registry.

The registry under a modern law is known as a "notice" registry. That is, it is a registry in which the secured creditor registers only a simple notice of the essential facts of the secured transaction, i.e. the identity of the debtor, the identity and contact information for the secured creditor, and a general or specific description of the collateral. A number of best practice principles for registries have been developed from the experiences of countries that have successfully implemented modern secured transactions systems. The provisions of the legal framework concerning publicity of security interests should enable the implementation of a registry that is characterized by these principles. The principles are as follow:

Accuracy: Accuracy refers to entry into the registry archive exactly the information that is provided by the registrant, who is the secured creditor or its agent. It does not refer to the accuracy of the information with respect to the true state of the facts. The burden is on the registrant to provide correct information. If the registrant provides inaccurate information, the 
secured creditor risks losing its priority if the error makes the notice undiscoverable. The burden of the registry is only to accurately capture the information that is provided.

Speed and timeliness: It is important that the archive reflect all effective notices as soon as they become effective, because a searcher must be able to rely on a search to reveal all effective notices of security interest in order to make financing decisions. A secured creditor must know that its notice is effective at the time it is registered so its priority is assured.

Accessibility: The registry must be accessible to both registrants and searchers from widely available access points, and without undue delay. The registry should be accessible at hours other than normal business hours of the registry.

Unity: The registry should include notices of all types of security interests in all types of movable property of all kinds of debtors, without regard to the location of the collateral within the country.

Cost effectiveness: The transactional cost of registration and searching should be limited to the level required to recover the costs of operation of the registry. The transactional cost must not deter users from registering.

Simplicity: Registration requirements must be kept as simple for the user as possible in order to eliminate errors and to encourage use.

Limited to purposes of registration: Registration information must satisfy the purposes of providing notice of potential security interests and securing priority, but should not provide information that is not relevant to those purposes. To add extraneous requirements unnecessarily burdens the true purpose of the registry and detracts from its utility.

Rule-based decision-making for acceptance of notices: The registry should apply a fixed, consistent set of rules to make decisions to accept or reject notices and to identify notices in response to a search request. Registration rules should be enforced by using automated edits at the time of data entry, so that decisions are made immediately upon submission of a notice. 


\section{Annex 9: Secured Transactions Registry - Analysis of Institutional Framework}

\section{Existing Institutional Framework}

\subsection{Property and Vehicles Registries (Cartorio):}

There is no legal framework and, hence, no institutional framework to support lending secured by movables with the narrow exception of title transfer to secure financing for motor vehicles. The two most important characteristics of the registration structure are:

Location: there is only one place where pledges and mortgages can be registered. There is no other option but to go to the capital and register it at the Cartorio. People from small towns or even from Principe have no possibility to do it at any government branch or other institution. This situation is far from ideal since most of the population have no access or means to get to the capital in Sao Tome so they are excluded of the system.

Document registration: the requirement to present all documentation causes delays and inconvenience. By requiring examination of the agreement for legal sufficiency, the document registration system introduces the potentials for arbitrary rejection of the registration and for error in indexing the registration.

\subsection{Registering property:}

According to the Doing Business report 2015, globally São Tomé and Príncipe stands at 148 in the ranking of 189 economies on the ease of registering property. The rankings for comparator economies and the regional average ranking provide other useful information for assessing how easy it is for an entrepreneur in São Tomé and Príncipe to transfer property. As shown in Table 9 the time, cost and procedures for registering a property are lengthy, very expensive and cumbersome.

Registration of mortgages requires the form of a notarial deed in the property registry, which means that the act was performed by the notary public. Individuals and companies do not own any land; the government owns all the land and that grants them the right to use. These rights, rather than the right of ownership, is registered in the land registry. However, registration of mortgages is mandatory for the creation of a security interest. If the real estate is already registered and all documentation is complete, then the registration of the mortgage takes about 3-4 days according to the property registry. 
Table: Summary of time, cost and procedures for registering property in São Tomé

\begin{tabular}{|c|c|c|c|}
\hline $\mathbf{N}^{\circ}$ & Procedure & Time to complete & Cost to complete \\
\hline \multirow{3}{*}{1} & $\begin{array}{l}\text { Obtain an updated ownership certificate at the Property Registry } \\
\text { (Registro Predial) }\end{array}$ & \multirow{3}{*}{$\begin{array}{l}23 \text { days } \\
\text { (simultaneous with } \\
\text { Procedure 2) }\end{array}$} & \multirow{3}{*}{ STD 65,000} \\
\hline & $\begin{array}{l}\text { The seller must obtain an updated ownership certificate at the Registro } \\
\text { Predial (Property Registry). This document will include all useful } \\
\text { information regarding the property. }\end{array}$ & & \\
\hline & Agency: Property Registry (Registro Predial) & & \\
\hline \multirow{3}{*}{2} & $\begin{array}{l}\text { * Obtain a copy of the incorporation documents at the Commercial } \\
\text { Registry Agency }\end{array}$ & \multirow{3}{*}{$\begin{array}{l}2 \text { days } \\
\text { (simultaneous with } \\
\text { Procedure 1) }\end{array}$} & \multirow{3}{*}{ STD 75,000 } \\
\hline & $\begin{array}{l}\text { A registered copy of the incorporation documents is obtained at the } \\
\text { Registro commercial (Commercial Registry Agency) in order to prove } \\
\text { the legitimacy of the buyer (a company). }\end{array}$ & & \\
\hline & Agency: Commercial Registry Agency (Registro Commercial) & & \\
\hline \multirow{3}{*}{3} & Tax Authority prepares assessment of property transfer tax (Sisa) & \multirow{3}{*}{2 to 3 weeks } & \multirow{3}{*}{$\begin{array}{l}\text { included in next } \\
\text { Procedure }\end{array}$} \\
\hline & $\begin{array}{l}\text { The Conveyance (Sisa) Tax must be filed at the Direcçao das Finanças } \\
\text { (Tax Authority). An assessment by official municipal employees is } \\
\text { required to certify the property value settled by the parties. Based on } \\
\text { this assessment the tax employees inform the investor by phone about } \\
\text { the amount due in tax }\end{array}$ & & \\
\hline & Agency: Tax Authority (Direçao das Finanças) & & \\
\hline \multirow{3}{*}{4} & Pay Sisa at the Central Bank & \multirow{3}{*}{1 day } & \multirow{3}{*}{$\begin{array}{l}8 \% \text { of property } \\
\text { value (SISA Lei } 5 \text { of } \\
\text { 2007) }\end{array}$} \\
\hline & $\begin{array}{l}\text { The buyer pays the conveyance tax at the central bank (all taxes are paid } \\
\text { at the central bank), who issues a receipt. }\end{array}$ & & \\
\hline & Agency: Central Bank & & \\
\hline & Obtain proof of payment from tax authority & \multirow{3}{*}{1 week } & \multirow{3}{*}{$\begin{array}{l}\text { included in } \\
\text { previous Procedure }\end{array}$} \\
\hline & $\begin{array}{l}\text { The buyer submits the tax payment receipt to the tax authority and } \\
\text { receives the proof of payment (certidão de Sisa) to be presented to the } \\
\text { notary. }\end{array}$ & & \\
\hline & Agency: Tax Authority (Direçao das Finanças) & & \\
\hline \multirow{3}{*}{6} & A public notary prepares and notarizes the sale purchase agreement & \multirow{3}{*}{$\begin{array}{l}7 \text { days is the usual } \\
\text { time, but time for } \\
\text { this Procedure can } \\
\text { vary from } 3 \text { days to } \\
2 \text { weeks }\end{array}$} & \multirow{3}{*}{$\begin{array}{l}\text { STD } 200,000+\text { STD } \\
1,500 \text { (stamp duty) }\end{array}$} \\
\hline & $\begin{array}{l}\text { The sale and purchase agreement must be notarized by a public notary } \\
\text { before the payment of taxes at the tax authority. }\end{array}$ & & \\
\hline & Agency: Notary & & \\
\hline & Apply for registration at the Registro Predial & \multirow{3}{*}{7 days } & \multirow{3}{*}{$\begin{array}{l}0.93 \% \text { of property } \\
\text { value (Registration } \\
\text { fee) }\end{array}$} \\
\hline 7 & $\begin{array}{l}\text { After obtaining confirmation of tax payments, the buyer applies for } \\
\text { registration at the Registro Predial. A new property registration } \\
\text { certificate is issued to the buyer. Internally, the Registry will inform the } \\
\text { Cadastre of the transfer so they update their records. According to } \\
\text { Despacho no.17/2012 of March } 14,2012 \text {, registration fees are paid at the } \\
\text { internal payment office of the Registry (Caixa Interna do Registo Predial) } \\
\text { if the amount to be paid is up to } 99,999 \text { STD. If registration fees are } \\
100,000 \text { STD or over, they are paid at a commercial bank. }\end{array}$ & & \\
\hline & Agency: Registry (Registo Predial) & & \\
\hline
\end{tabular}

Source: World Bank Doing Business Database 


\subsection{Vehicles registry:}

The device that they use is a transfer of title to the lender, which has to be registered as a pledge ("penhor"). As noted previously, there is no legal framework in Sao Tomé and Principe to support non-possessory interests in the movable property of individuals. Therefore, lenders must look to other devices to meet the demand for financing the purchase of vehicles by both businesses and individuals. It is straightforward, though not without risk.

A lender may simply do a title transfer by registering it with the Vehicles Registry for a fee that is based on the type of vehicle, and difficult to understand. It also needs to submit a power of attorney that provides the recognition of the parties' signatures by the notary (and its cheaper and faster than the public deed). The lender then keeps title until the obligation is paid by the borrower, and then transfers the title to the borrower, again by registering with and paying the fee to the Vehicles Registry. ${ }^{51}$

While title transfer may seem simple, it takes up to 8 days, but it's the only option available for such financing. It also has some serious drawbacks, the most apparent is the expense of registering two title transfers, once when transferring to the lender and once when transferring it back to the borrower.

\subsection{Fees:}

Fees for registration of mortgages and pledges are published in the Despacho Conjunto no 13/2011 (Article 47). In this same document are also included the fees for title registration of vehicles and property as well as notaries fees. There are different fees depending on the transaction and are calculated based on the secured amount. For vehicles some fees are flat and depends on the type of vehicle. Most institutions interviewed complained about the complexity to understand the table of fees and that most of the times there is no transparency in the process.

Another important observation is the lack of capacity and resources within the Cartorio. There are very few registry staff and they have to hire retired people to be able to perform their services. ${ }^{52}$

\subsection{Public Credit Registry (Central de Riscos de Crédito)}

The current Credit Registry (CRC) managed by the Central Bank of Sao Tomé and Principe (BCSTP) has a solid and modern interface, a well-versed and skilled BCSTP CRC managing staff and the potential availability of a relevant amount of data and good quality of the contributors Management Information Systems. However, according to the gap analysis performed by Microfinanza as part of the mission, the CRC is today largely underutilized in Sao Tomé mainly

\footnotetext{
51 Interview with Mr. Salifu Mansary, Road Traffic Authority.

52 Interview with Director of the Property and Vehicles registry.
} 
due to: (i) imperfect quality of the information of the CRC; (ii) lack of some relevant information in the data contribution and (iii) lack of functions/reports in the consultation platform.

Financial infrastructure is the foundation of a country's financial system including the legal and regulatory framework for financial sector operations. Credit reporting and collateral registries are crucial components of the financial infrastructure as they serve access to finance and financial stability. Comprehensive and well-functioning credit reporting systems reduce information asymmetries support efficient credit allocation and strengthen risk management. Effective collateral registries enable entrepreneurs to leverage their movable property as collateral for both business and consumers credit.

If the Central Bank decides to implement the necessary upgrades of the CR (both in terms of security and upgrades of the process, functions, reports and resources) there will be a huge potential for building economies of scale and potentially host the Collateral Registry within the same technology platform. In other jurisdictions, both systems share the same premises, hardware and resources, even when the software systems as well as the databases should be treated separately. It would also be very beneficial to the financial sector if Pass a modern legal framework for secured transactions and electronic collateral registry in place.

\subsection{Companies Registry (Guiche Unico de Empresas):}

The Guiche Unico de Empresas (GUE) is the one stop shop for businesses registration. It was developed with the technical support of IFC in 2010. Currently, new companies are registered with GUE and businesses registered under the old system are transferred to GUE whenever the business undertakes an activity at GUE's one-stop shop such as an update or modification. As of December 2014, 1,225 new companies have been registered in GUE and 1,335 businesses have been transferred from the old system.

Table: Number of registered companies at GUE

\begin{tabular}{|c|c|c|c|}
\hline Year & $\begin{array}{l}\text { New } \\
\text { companies }\end{array}$ & $\begin{array}{l}\text { Old } \\
\text { companies }\end{array}$ & \\
\hline 2010 & 57 & & \\
\hline 2011 & 238 & & \\
\hline 2012 & 354 & \multirow{3}{*}{1135} & \\
\hline 2013 & 294 & & \\
\hline 2014 & 312 & & TOTAL \\
\hline TOTAL & 1255 & 1135 & 2390 \\
\hline
\end{tabular}

Source : GUE database

The process to create a new company can be done through the website in 15 minutes. The link to the website is: http://www.gue-stp.net/. The software was developed by Silvernote, which is a local company, and the database is in the cloud. The registration fee is flat (\$200) for any type of company. Regarding the registration of pledges, there is no law in Sao Tome and Principe that 
would impede to do it in the GUE, it could be done in presence bringing the necessary documents, although it has not been done in practice. ${ }^{53}$

\subsection{Evaluation of Institutional Framework}

The existing registry structure, therefore, fails to conform to the best practices set forth in previous sections. The process for registration of pledges is evaluated against each best practice as follows:

Accuracy: In the existing process, a registrar reviews and indexes information manually from the agreement and the registration form into a paper book. Whenever an intermediary, e.g. registrar, exercises discretion and keys in information, there is a serious risk of error that may make the information ineffective as notice. Therefore, the existing process does not assure that information is accurately entered as received.

Speed and timeliness: While the turn-around time for registration is not excessive for a system in which data must be entered by a registrar, there is still a gap during which a searcher would not find a notice that has been received by the registry. Further, it seems searches are not performed often given that the pledges are only done on vehicles and the transfer of title is required and therefore no need for a search.

Accessibility: Registrants must come to the registry during business hours, so there is inevitable delay in getting to the registry. The existing system is not, therefore, easily accessible either as to place or time.

Unity: The registry does not include registrations of interests other types of movable property such as accounts receivable, inventory, etc. In addition, registrations can only be done at the premises in Sao Tome, there is no other registry for mortgages and pledges.

Cost effectiveness: The fees are based on the loan value and are higher than would be required for a modern electronic registry. With respect to loans to commercial entities, double registration is necessary, thereby doubling the registration fee expense. The greater costs of the existing registry are the costs of preparation and delivery of the information form and the documents. So the existing registry is not as cost effective as it could and should be.

Simplicity: The existing registration process is both an information and document registration system, meaning that the parties must ensure that the agreement complies with the outdated requirements of the Civil Code including the stamp duties. It is unnecessarily complicated and inconvenient, far removed from simple notice registration.

\footnotetext{
53 Interview with GUE director and team.
} 
Limited to purposes of registration: Registration is mandatory, and failure to register is an offense, so it goes well beyond simply providing notice. Further, the information that is entered in the books goes far beyond what is necessary to give effective notice to third parties.

Rule-based decision-making for acceptance of notices: The registrar examines the documentation for compliance. Therefore, the process requires the exercise of judgment by the registrar, so results may be uncertain. The process is not, therefore, based on objectively applied rules.

\section{Recommendations}

\subsection{Designate an entity responsible for the collateral registry.}

If the Government of Sao Tomé and Principe decides to embark on a secured transactions reform, should start considering who could be the potential host for the collateral registry. Reluctance of local stakeholders to take responsibility for the establishment of a collateral registry has negatively affected many other projects in other regions. In Kenya, a similar project has never taken off for this reason. The designation of the entity to operate the collateral registry may be made at any moment during the implementation process. Most countries designate the responsible entity in their secured transactions law (e.g. Ghana, Liberia, and Mexico) so it is recommended to designated in the law.

Countries have implemented various models. In some, the collateral registry is hosted by the Central Bank itself, such as in Ghana and Liberia. In others, an already existing agency that has some experience with the registration of rights and interests, such as PACRA in Zambia and the Registrar General's Office in Malawi, have been designated as the hosts. A third possible model is where the Government itself, typically the Ministry of Justice (e.g., in Slovakia) or the Ministry of Economy (e.g., in Mexico) is in charge. Finally, in a handful of countries, the private sector has been charged with the establishment and operation of the collateral registry (e.g., the Confederation of Chambers of Commerce in Colombia and the Chambers of Commerce of Tegucigalpa and San Pedro Sula in Honduras). It is important that the host is a reputable entity that has both the professional and technical capabilities to operate a registration system.

2.2 Based on the diagnostic mission, there are three potential options in terms of where the collateral registry could be hosted at:

Credit Registry (Central do Risco): as previously noted, there are multiple synergies between a credit reporting system and a collateral registry. They manage similar data and have same beneficiaries. In addition, they can share the same technology platform to have economies of scale by sharing IT resources (hardware, disaster recovery site, etc.), premises or even information. However, in order for this to happen the credit registry would need serious upgrades in technology and resources as already highlighted. 
Outsourced private sector solution: there are international vendors who can provide this service at a reasonable monthly fee by managing and hosting all the data in the cloud. This is the solution that various islands in the Pacific had adopted and other countries such as Haiti or the Dominican Republic are exploring.

Business registry (Guiche Unico para Empresas): the one-stop shop online system for the creation of companies has been operating for a few years already. The institution has the knowhow and capacity to run a modern electronic system like the collateral registry. As mentioned previously, this is the model that some countries in Africa as well as Latin America are using as it also facilities the exchange of information between both registries and brings economies of scale to the county.

Ultimately, in order to consider a possible designation of the entity responsible of operating the collateral registry, it should be assessed if it indeed possesses the necessary technical capability, the human resources for operative and technical matters, such as the technical support of users, etc. Nevertheless, São Tomé and Principe could designate other entities to operate the collateral registry from the public and the private sector. If a non-governmental office is designated, it is still important that the government assumes ultimate responsibility for the data recorded in the collateral registry.

\section{Potential Action Plan}

\subsection{Objective}

The objective would be to increase access to credit to the private sector in São Tomé and Príncipe by improving secured lending framework, strengthening lenders' rights in movable assets and raising awareness about secured transactions among local stakeholders.

\subsection{Project Scope/Description}

The reform can be implemented in there phases:

\section{Conducting Comprehensive Legal Reform- 12 months}

The first phase should focus on supporting the drafting and the enactment of the necessary laws/amendments into laws governing secured transactions. This work will start by conducting a comprehensive legal diagnostic/assessment with the support from the locally hired legal advisor who will work in close collaboration with the international expert. The legal diagnostic will help identify the most appropriate form of implementing the reform and will be used as a basis for drafting necessary laws/amendments into laws.

\section{Developing and establishing the electronic Collateral Registry- 9 months}


Upon enactment of the relevant legislation, the reform will focus on developing the on-line Collateral Registry, which will replace the less effective existent paper based registry

Work on development of the registry can start once the secured transactions law and coordinating amendments have been enacted or when there is a high degree of certainty that they will be passed. The reason for this is that the collateral registry will not be effective to establish the priority of competing interests in collateral without the legal framework being in place, but the law cannot function without a registry up and running.

\subsection{Capacity building of stakeholders- continuous activity}

Thirdly, once the legal, regulatory and institutional framework is in place, the Project will work with relevant stakeholders on raising awareness about new tools and will conduct capacity building programs for financial institutions, businesses, judges and lawyers.

3.4 The reform should also:

- Support the public awareness campaign, targeting stakeholders with information on the new secured transactions law, registry system and their economic benefits.

- Train managers and staff of the government entity that manages the registry.

\section{5 Expected Outcome}

- Law on secured transactions and necessary by-laws that conform to the best practice are enacted;

- The Secured Transactions Registry is operational;

- Banks and other finance institutions expanding the lending operations where movable properties such as accounts receivable, inventory and equipment are used as collateral. 


\section{Annex 10: List of Individuals Met}

Ministro das Finanças e Administração

Pública

Dr. Américo de Oliveira Ramos, Ministro do Plano e Financas

Ministro da Economia e Cooperação Internacional

Dr. Agostinho Fernandes

Ministra da Justiça da Justiça e dos Direitos Humanos

Dr. Roberto Raposo

Banco Central de São Tome e Principe Dra. Maria do Carmo Silveira, Governador

Dr. Umberto Neto, Conselho de Administrão

Dra. Lara Beirão, Directora de de Supervisão,

Dr. Ayres Costa, Central de Risco

Dra. Esperanca Santiago, Directora de Estudos Economicas

Dra. Antonia Santana, Directora de Estatisticas

Private Sector Stakeholders and Civil

Society

Banco Internacional de STP

Afriland First Bank

Ecobank

BGFI

Energy Bank

SAT Insurance

Nicon

Credial

CST
UNITEL

Guichet Único

Camara de Comércio, Indústria, Serviços e

Agricultura

Associação Comercial

Associação dos Jovens Empresários de Iniciativa Empresarial

Associação das Mulheres Empresárias

Federação Nacional dos Pequenos

Agricultores (FNAPA)

Cooperativa de Cacau Biológico (CECAB)

Cooperativa de Cacau de Qualidade

(CECAQ11)

Cooperativa de Café Biológico (CECAFEB)

Fórum dos Empreendedores

Ordem dos Advogados

Ordem dos Contabilistas

Associação Empresarial

International Monetary Fund

Maxwell Opoku-Afari

Dalmacio F. Benicio

Jehann Jack

World Bank Group

Julián Casal, Financial Sector Economist

Mazen Bouri, Senior Financial Sector

Specialist

Christopher Juan Costain, Lead Financial

Sector Specialist

Elsa Rodriguez, Financial Sector Specialist

Dave Grace, Consultant

Adelino Santiago Castelo David, Consultant António Manuel Baptista, Consultan 